\section{To: (Receiving Organization)}

Distribution

5. Proj./Prog./Dept./Div.:

W-151 300 HP Mixing Pumps

8. Originator Remarks:

This EDT releases the test report for the operational checkout and demonstrates Project $W-151$. Design verification is by informal method. Cognizant Manager signature also signifies design verification.*

11. Receiver Remarks: 11A. Design Baseline Document? [] Yes [X] No None.

6. Design Authority/ Design Agent/Cog. Engr.:

\section{B. G. Berglin} performance of three 300 HP Mixing Pumps ( $90908-1,90908-2$, and $90908-3$ ) provided by

\section{From: (Originating organization) FFTF}

$N / A$

9. Equip./Component No.: $\mathrm{N} / \mathrm{A}$

10. System/Bldg./Facility: $N / A$

12. Major Assm. Dwg. No.: $N / A$

13. Permit/Permit Application No.: N/A

14. Required Response Date:

N/A

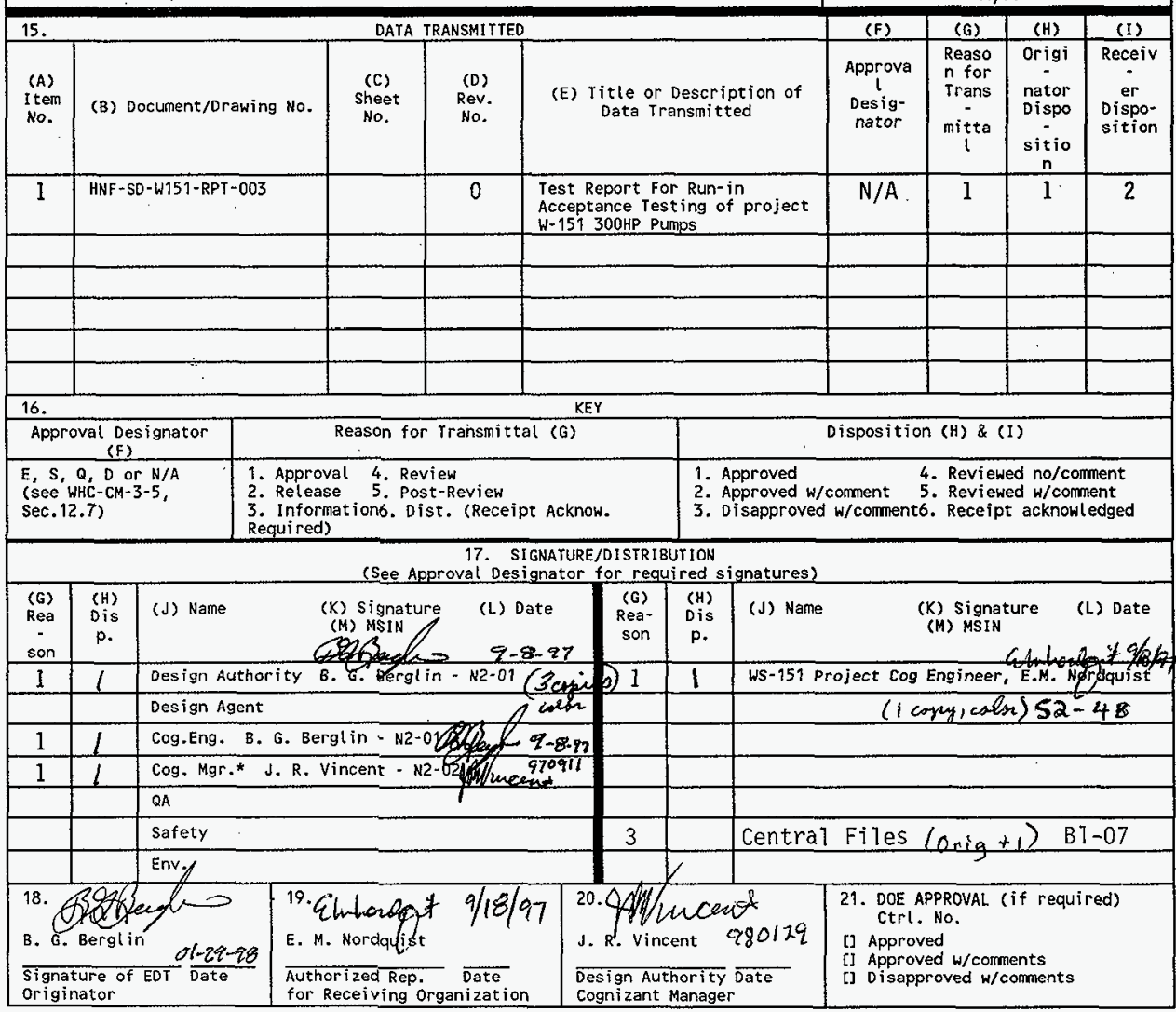




\title{
TEST REPORT FOR RUN-IN ACCEPTANCE TESTING OF PROJECT W-151 300 HP MIXING PUMPS
}

\author{
B. G. Bergl in
}

B\&W Hanford Company, Richland, WA 99352

U.S. Department of Energy Contract DE-AC06-96RL13200

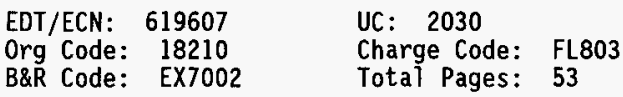

Key Words: $W-151 ; 300$ HP Mixing Pumps Test Report

Abstract: This report documents the results of a performance demonstration and operational checkout of three $300 \mathrm{HP}$ mixer pumps in accordance with WHC-SD-W151-TS-001 "Mixer Pump Test Specification for Project W-151" and Statement of Work 8K520-EMN-95-004 "Mixer Pump Performance Demonstration at MASF" in the 400 Area Maintenance and Storage Facility (MASF) building. Testing of the pumps was performed by Fast Flux Test Facility (FFTF) Engineering and funded by the Tank Waste Remediation System (TWRS) Project $W-151$. Testing began with the first pump on 04-01-95 and ended with the third pump on 11-01-96. Prior to testing, the MASF facility was modified and prepared to meet the pump testing requirements set forth by the Test Specification and the Statement of Work.

TRADEMARK DISCLAIMER. Reference herein to any specific comerciat product, process, or service by trade name, trademark, manufacturer, or otherwise, does not necessarily constitute or inply its endorsement, recommendation, or favoring by the United States Govermment or any agency thereof or its contractors or subcontractors.

Printed in the United States of America. To obtain copies of this document, contact: Document Control Services, P.0. Box 950, Mailstop H6-08, Richland WA 99352, Phone (509) 372-2420; Fax (509) 376-4989.
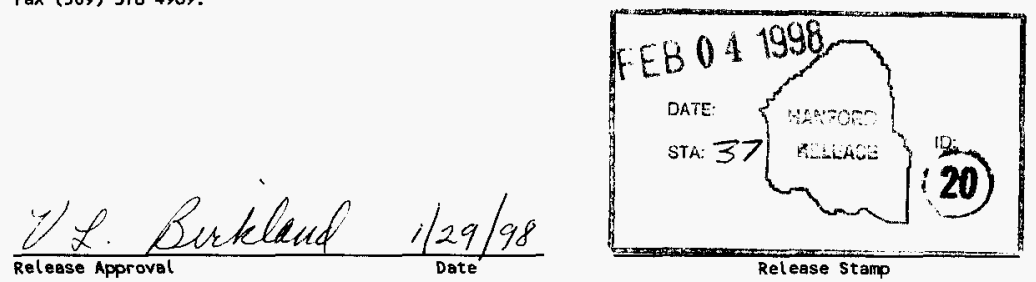
HNF-SD-W151-RPT-003

REV. 0

\section{TEST REPORT FOR RUN-IN ACCEPTANCE TESTING OF PROJECT W-151 300 HP MIXING PUMPS}

Prepared by Brian G. Berglin

B\&W Hanford Company

Hanford Operations and Engineering Contractor

for the

U. S. Department of Energy

Richland Operations 
3.0 TEST METHOD AND TEST EQUIPMENT $\ldots \ldots \ldots \ldots \ldots \ldots \ldots$ Page 1

3.1 Prerequisites of Test Performance .............. Page 1

3.1.1 Preparation of the MASF Facility . . . . . . . . . . Page 1

3.1.2 Document Preparation .................. Page 3

3.2 Instruments and Equipment Used ................. Page 4

3.3 Method of Test Performance .................. Page 6

3.3.1 Test Specification Parameters of LDCV ............ Page 6

3.3.2 Preparing Mixer Pump for Installation into LDCV . . . . . Page 7

3.3.3 Installation of the Mixer Pump into the LDCV ......... Page 7

3.3.4 Preparing the Mixer Pump for Operation .......... Page 8

3.4 Mixer Pump Performance Demonstration ................ Page 9

3.5 Approved Deviations to Test Specs and Statement of Work ... Page 9

4.0 TEST RESULTS $\ldots \ldots \ldots \ldots \ldots \ldots \ldots \ldots \ldots \ldots \ldots \ldots$ Page 10

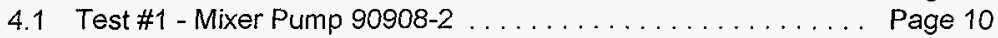

4.1.1 Pre-existing conditions ................. Page 10

4.1.2 Initial Demonstration Test . . . . . . . . . . . . . . . . . Page 10

4.1.3 MASF Facility Upgrades . . . . . . . . . . . . . . Page 12

4.1.4 Test Data Comparison with LPI Testing . . . . . . . . . Page 13

4.1.5 Lower Mechanical Seal Design Flaw .............. Page 14

4.1.6 Column Water Flow through the Lower Mechanical Seal. Page 14

4.1.7 Turntable Installation .................. Page 14

4.1.8 Lower Mechanical Seal Installation . . . . . . . . . . . Page 15

4.1 .9 Performance Demonstration ................. Page 15

4.1.10 Post Lower Seal Decay Pressure Test ......... Page 18

4.1.11 Mixer Pump Removal .................... Page 18

4.2 Test \#2 - Mixer Pump 90908-1 . . . . . . . . . . . . . . . . Page 18

4.2.1 Prerequisites to Testing $\ldots \ldots \ldots \ldots \ldots \ldots \ldots$ Page 18

4.2.2 Pre-existing conditions $\ldots \ldots \ldots \ldots \ldots \ldots \ldots \ldots$ Page 19

4.2.3 Performance Demonstration ................ Page 19

4.2.4 Post Lower Seal Decay Pressure Test . . . . . . . . . . . Page 20

4.2.5 Mixer Pump Removal \& Restoration ............. Page 20

4.3 Test \#3 - Mixer Pump 90908-3 . . . . . . . . . . . . . . Page 20

4.3.1 Prerequisites to Performance Demonstration ....... . . . Page 20

4.3.2 Pre-existing conditions . .................. Page 21

4.3.3 Performance Demonstration ................ Page 21

4.3.4 Post Lower Seal Decay Pressure Test . . . . . . . . . . . . Page 22

4.3.5 Mixer Pump Removal . . . . . . . . . . . . . . . . . Page 22

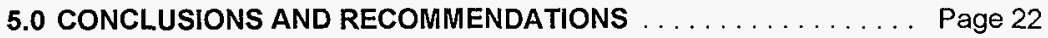

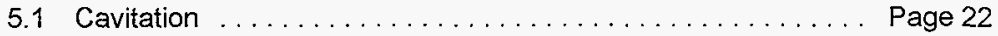

5.2 Mixer Pump Motor Characteristics ............... Page 23 
5.3 Pump Vibration . . . . . . . . . . . . . . . . . . Page 23

5.4 Pump Column Temperatures . . . . . . . . . . . . . . . Page 24

5.5 Motor Temperatures ....................... Page 24

5.6 Lower Seal Water Flow (Pump Column Flow) . . . . . . . . Page 25

5.7 LDCV Tank Water Temperature .................. Page 26

6.0 DISPOSITION OF TEST ITEMS $\ldots \ldots \ldots \ldots \ldots \ldots \ldots \ldots \ldots$ Page 27

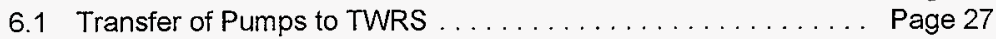

6.2 Mixer pump Storage ...................... Page 27

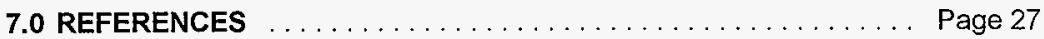

7.1 Work Packages . . . . . . . . . . . . . . . . . . Page 27

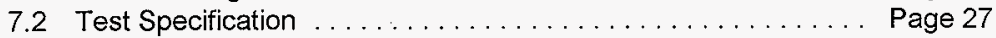

7.3 Statement of Work ...................... Page 27

8.0 APPENDIXES $\ldots \ldots \ldots \ldots \ldots \ldots \ldots \ldots \ldots \ldots \ldots \ldots$ Page 27

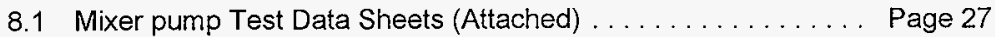

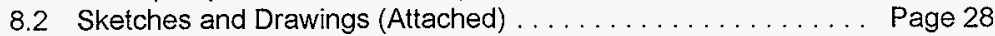

8.2.1 SKETCH OF 300 HP MIXER PUMP TEST SETUP . . . . Page 28

8.2.2 Elevation of 6 " Vertical Line Shaft Bearing Pump . . . . . Page 28

8.2.3 Lower Mechanical Seal Vendor Drawing ........... Page 28

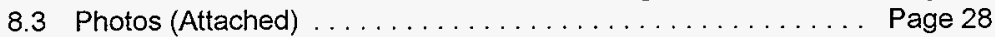

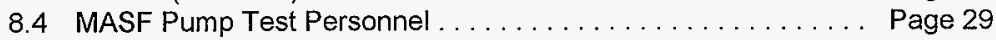




\section{HNF-SD-W151-RPT-003 \\ REV 0}

\subsection{INTRODUCTION}

This report will document the results of a performance demonstration and operational checkout of three $300 \mathrm{HP}$ mixer pumps in accordance with WHC-SDW151-TS-001 "Mixer Pump Test Specification for Project W-151" and Statement of Work 8K520-EMN-95-004 "Mixer Pump Performance Demonstration at MASF" in the 400 Area Maintenance and Storage Facility (MASF) building.

Testing of the pumps was performed by Fast Flux Test Facility (FFTF) Engineering and funded by the Tank Waste Remediation Site (TWRS) Project W-151. Testing began with the first pump on 04-01-95 and ended with the third pump on 11-01-96.

Prior to testing, the MASF facility was modified and prepared to meet the pump testing requirements set forth by the Test Specification and the Statement of Work.

\subsection{DESCRIPTION OF TEST}

The Mixer pumps tested are identical and a production item from LPI built as a production pump to the specifications provided by the TWRS Hanford Site Contractor. Three Lawrence Pump Incorporated (LPl) 300 HP Mixer pumps were tested individually in the MASF Large Diameter Cleaning Vessel (LDCV) and documented as follows:

\begin{tabular}{|c|c|c|}
\hline Test Number & LPI Mixer Pump Serial Number & Test Work Package Number \\
\hline 1 & $90908-2$ & $4 A-95-81 / \mathrm{M}$ \\
\hline 2 & $90908-1$ & $4 \mathrm{~A}-95-80 \mathrm{~W}$ \\
\hline 3 & $90908-3$ & $4 \mathrm{~A}-95-118 \mathrm{~W}$ \\
\hline
\end{tabular}

\subsection{TEST METHOD AND TEST EQUIPMENT}

\subsection{Prerequisites of Test Performance}

\subsubsection{Preparation of the MASF Facility}

Before the Mixer Pump equipment checkout and performance demonstration test could be performed in MASF, equipment installation and MASF modifications to perform a Mixer Pump test were required . The equipment installation and MASF modifications are listed below: 


\section{HNF-SD-W151-RPT-003 REV 0}

\subsubsection{300 HP Mixer Pump Support Platform}

The existing platform installed over the LDCV for the 101SY Hydrogen Mitigation Pump Testing was neither high or strong enough to allow use of it by the 300 HP Mixer pumps. TWRS designed and built a platform with a removable section due to height constraints in MASF. The platform was delivered to MASF for completion of installation. The existing pump platform was removed from over the LDCV and the new 300 HP Mixer Pump platform was installed over the LDCV per work package 4A-95-007 $\mathrm{N}$ on 07-05-95.

\subsubsection{LDCV Bleed/Drain Water System}

Since the mixer pump testing level requirements were 14 ' lower than the previously tested 101SY Hydrogen Mitigation Retrieval Pumps, the existing bleed line entering through the top of the LDCV was extended. This was a temporary modification due to the problem of draining the existing water from the LDCV to the 400 Area effluent stream and the urgency to perform the mixer pump test. Another concern was the fatigue factor of the long moment arm of the bleed line extending down into the water of the LDCV during full speed testing. Although this method for testing the 90908-2 pump was initially used (expanded upon in Section 4), funding and time became available to install a bleed/drain line off the bottom of the LDCV with a designated pump and control switch. FFTF Engineering (herinafter referred to as FFTF) designed and installed the new bleed/drain line so the LDCV could also be drained and used as a bleed system to maintain temperature of the water during pump testing.

\subsubsection{Hot Water System}

The existing MASF Hot Water Tank (HX-2001) and associated piping feeding the lower portion of the LDCV had never been put into service and was blanked off from the LDCV. This system was modified, connected and acceptance tested by FFTF so up to $200^{\circ} \mathrm{F}$ water could be supplied to the LDCV prior to starting the Mixer Pump in order to meet the test requirements. HX-2001, the $1800 \mathrm{KW}$ Hot Water Heater presented many challenging leaks around the heating elements during the effort to start it up and operate it. Some heating elements were replaced in an effort to provide 


\section{HNF-SD-W151-RPT-003}

\section{REV 0}

adequate heating capabilities while others were disconnected to minimize the cost.

\subsubsection{Feed Water System}

The Feed Water line was modified slightly to utilize the process water supply just below the floor penetration to the west of the LDCV. This enabled flexibility by MASF Operations and Pump Testing personnel to use process water without impacting the schedule of the mixer pump test or MASF Facility Operations work.

\subsubsection{Motor Control Center}

A new permanant Motor Control Center was installed in the MASF Facility to supply power for mixer pump testing.

\subsubsection{Document Preparation}

\subsubsection{Statement of Work}

The Statement of Work was provided by TWRS and approved by FFTF. In addition, FFTF provided a Cost Estimate and Schedule to TWRS reflecting the scope of work.

\subsubsection{Test Specification}

The Test Specification was prepared by TWRS and approved by FFTF.

\subsubsection{Critical Lift Procedures}

Three Critical Lift Procedures (CLP) were prepared by FFTF and approved by the FFTF facility pertinent personnel. The first CLP off loaded the mixer pumps from the receiving truck inside the MASF high bay area. The second CLP included the contents from the first CLP, but also included installation and removal from the floor to the LDCV and loadout of the mixer pump onto a truck for transport out of the MASF building. The third CLP was similar to the second CLP except for the deletion of the $\mathrm{QC}$ requirements. 


\section{HNF-SD-W151-RPT-003 \\ REV 0}

\subsubsection{Work Packages}

Three work packages were prepared by FFTF and approved by appropriate FFTF personnel to facilitate test equipment installation and MASF modifications required to test each of the mixer pumps and to control and document each mixer pump performance and demonstration test separately. Section $3 \& 7$ list the work package numbers related to each test.

3.2 Instruments and Equipment Used

Most equipment, components and instruments were provided by the Project $W-151$. Some components, instrumentation and equipment were provided by FFTF. The general equipment, components and instruments required to perform the performance and demonstration test of the three mixer pumps are listed as follows:

3.2.1 Pump and Motor

Manufacturer:

LPI/Reliance

Power Requirements: 460 volt, 3 phase, $60 \mathrm{~Hz}, 360$ amps

Horsepower: 300

Motor Speed:

1200 RPM (maximum)

Rated Flow:

10,364 GPM

3.2.2 Variable Frequency Drive (VFD)

Manufacturer: Reliance Corporation

Model:

8 ED 1300

Input: $480 \mathrm{~V} / 3 \mathrm{PH} / 6 \mathrm{OHz} / 380 \mathrm{Amps}$ RMS

Output: $70480 \mathrm{~V} / 3 \mathrm{PH} / 1-60 \mathrm{~Hz} / 360 \mathrm{Amps}$ RMS

Nominal Horsepower: $\quad 300 @ 460$ volts

Enclosure:

NEMA 1

\subsubsection{Turntable Drive Assembly}

$7 / 3$ HP Reliance duty Master Motor with a reliance GP 2000 variable frequency drive, $1725 \mathrm{RPM}, 230$ volt, 3 phase, $60 \mathrm{~Hz}$ coupled to a Boston Gear Series FWC 732 double reduction worm gear, 900 to 1 ratio. A ring and pinion gear drive provide the final coupling to the pipe column that supports the pump and oscillates through 180 degrees at a variable speed of 0.05 to $0.2 \mathrm{rpm}$. The turntable drive assembly and position encoder was setup and verified to fit mechanically but was not electrically operated. 


\section{HNF-SD-W151-RPT-003 \\ REV 0}

\subsubsection{Support Column}

A $16^{\prime \prime} \mathrm{OD}$ tube in multiple sections positions the pump bowl at the bottom of the tank, The over-all length of the pump from top cover plate to pump inlet is approximately 58 feet. The pump intake requires, at a minimum, 7 " clearance from the bottom of the tank.

\subsubsection{Control Console}

The control console and related VFDs controlling mixer pump operation were not used for these tests. The existing Eaton VFD used on previous pump tests at MASF was modified specifically for the $300 \mathrm{hp}$ mixer pump tests. Following, the Eaton VFD and its control panel were substituted in place of the control console and related VFDs.Instrumentation

3.2.5.1 Temperature Element, bearings ( 2 supplied with motor) (100 $\mathrm{Ohm}$ at $0^{\circ} \mathrm{C}$ RTD) located at upper and lower motor bearings

3.2.5.2 Temperature Element, motor windings ( 3 supplied with motor) (10 Ohm at $25^{\circ} \mathrm{C}$ RTD) located internal to motor.

3.2.5.3 Vibration transducers, motor bearing ( 3 supplied by LPI) located external to pump

3.2.5.4 Three vibration transducers (Industrial Monitoring Instrumentation Model V0326A01) at the pump bowl (supplied by $\mathrm{LPI}$ located external to pump at the inline, axial and $90^{\circ}$ positions and connected to multimeters to record the vibration readings in milliamps.

3.2.5.5 Vibration anaylzer supplied by FFTF that is compatible with the above transducers.

\subsubsection{MASF Facility}

\subsubsection{LDCV and Mixer Pump Support Structures}

The LDCV is a stainless steel tank that is $38^{\prime}-6^{\prime \prime}$ high, $9^{\prime}$ in diameter with a eliptical bottom. The maximum capacity is 18431 gallons of water at the $38^{\prime}$ level. Three separate structures are installed over the LDCV to support mixer pump testing in the LDCV. Directly over the LDCV is a "support adapter" originally designed and installed by FFTF to install an 


\section{HNF-SD-W151-RPT-003}

\section{REV 0}

FFTF Primary Sodium Pump into the LDCV. Above the support adapter, a "pump stand" is installed specifically for pump testing (reference drawing H-4-302194). Above the pump stand is a "support fixture" (reference drawing H-4302015) specifically designed by TWRS to test the $300 \mathrm{HP}$ Mixer pumps at MASF.

\subsubsection{Feed, Bleed and Hot Water Systems}

The Feed system is connected to the MASF process water system which provides water to fill the LDCV and feed water for cooling during Pump Testing in the LDCV. A branch line off of the feed water line (referred to as bearing water on the drawing) provides pressure controlied filiered water to the mixer pump column. This portion of the system also consist of a pressure control valve to control the pressure and two flow meters to monitor the flow to the pump column. The bleed system provides water removal capabilities from the LDCV during pump testing and the ability to drain the LDCV in between pump tests. The hot water system provides up to $200^{\circ} \mathrm{F}$ hot water through a heater to the LDCV. This enables a Mixer Pump to be started in a hot environment simulating the environment in the 200 Area tanks.

\subsubsection{Electrical Power}

480 volt, 3 phase power was provided for the mixer pumps from a MASF designated MCC.

\subsubsection{Instrumentation}

Various multimeters, temperature readout devices, pressure gauges were provided by FFTF to record the Mixer Pump parameters required by the test specification.

\subsection{Method of Test Performance}

\subsubsection{Test Specification Parameters of LDCV}

Maximum liquid level in the MASF LDCV tank - $35^{\prime}$

Test liquid level - 22' (submergence above the tested Pump intake at $200^{\circ} \mathrm{F}$ )

Minimum liquid level - 4' (submergence above the tested Pump intake at $\left.170^{\circ} \mathrm{F}\right)$ 


\section{HNF-SD-W151-RPT-003 \\ REV 0}

Test liquid temperature in the LDCV $-200^{\circ} \pm 10^{\circ} \mathrm{F}$

Test liquid - water

\subsubsection{Preparing Mixer Pump for Installation into LDCV}

3.3.2.1 Install the pump vibration bowl transducers in the axial, in-line and $90^{\circ}$ direction and route the instrument cable up the pump column.

3.3.2.2 Remove the wooden shaft stabilizer.

3.3.2.3 Remove the tape on the end of the seal leakage return line and discharge nozzles.

3.3.2.4 Replace the 100 psi rupture disc on the Casing Flush line with a blind flange.

3.3.2.5 Flush all chips and debris from the sparge lines and spray ring nozzles.

3.3.2.6 Lube turntable bearings.

\subsubsection{Installation of the Mixer Pump into the LDCV}

3.3.3.1 Install the mixer pump turntable on the pump (90908-1 only).

3.3.3.2 Remove a section from the support platform required because of the height capabilities of the facility.

3.3.3.3 Upright the mixer pump and turntable to the vertical position using the MASF high bay overhead bridge crane.

3.3.3.4 Fill the lower mechanical seal area with filtered process water.

3.3.3.5 Insert the mixer pump into the LDCV and secure the turntable to the support fixture as shown in Photo \#1 \& \#2 of Section 8.3. If the LDCV was full of water, the pump column must be filled to at least tank level prior to inserting it into the LDCV to eliminate any possible leakage from the LDCV tank through the lower seal into the pump column. Different insertion methods were implemented on the following mixer pump tests following. For the second test, the Mixer Pump was installed into a dry LDCV. Following, the third test had water in the LDCV prior to insertion, so the Mixer Pump column was pressurized with 60 lbs of air before insertion into the LDCV.

3.3.3.6 Lift and install the motor onto the turntable

3.3.3.7 Align and couple the motor shaft to the pump shaft

3.3.3.8 Route power from the MASF Motor Control Center (MCC) to the VFD.

3.3.3.9 Route power from the VFD up to the local disconnect switch located on top of the support platform. 
HNF-SD-W151-RPT-003

REV 0

3.3.4 Preparing the Mixer Pump for Operation

NOTE: Reference Section 8.2.1 "SKETCH OF 300 HP MIXER PUMP TEST SETUP" and 8.2.2 "Elevation of 6" Vertical Line Shaft Bearing Pump".

3.3.4.1 Connect the power to the Mixer Pump from the local disconnect at the top of the support platform.

3.3.4.2 Install the bearing water supply piping to supply valve $S$ with a 60 psi pressure relief valve from the Feed Water Supply flexible piping connection.

3.3.4.3 Install a vent line with the 60 psi pressure relief valve relief line connected to it for venting and routing of any water relief of the bearing water piping to the LDCV.

3.3.4.4 Instrumentation.

3.3.4.4.1 Verify VFD settings are correct to provide the proper Volts, Amps and RPM to the motor.

3.3.4.4.2 Connect the casing vibration (axial, in-line and $90^{\circ}$ positions) cable connections to multimeters that will track the vibration in milliamps.

3.3.4.4.3 Connect the Stator, upper bearing and lower bearing temperature RTD's to digital readout devices in ${ }^{\circ} \mathrm{F}$.

3.3.4.4.4 Connect RTD's to the outside of the upper and lower pump column to a digital readout device in ${ }^{\circ} \mathrm{F}$.

3.3.4.4.5 Installed temporary $115 \mathrm{~V}$ power to the flow meter on the bearing water supply line.

3.3.4.4.6 Verified that the RTD on the LDCV tank water temperature was in operating condition.

3.3.4.4.7 Obtain a vibrameter so the vibrations of the Lower, Upper and Thrust bearings on the motor can be taken and recorded throughout in units of IN/SEC.

3.3.4.5 Installed pressure gauges on the Upper Seal Inlet and Pump Column Vent line. Verified that the bearing water Pressure Control Valve (PCV) inlet and bearing water PCV outlet pressure gauges were in operating condition.

3.3.4.6 Filled pump column with filtered water through the bearing water supply system.

3.3.4.7 Established upper mechanical seal water pressure of $50 \mathrm{psig}$. Adjusted PCV on the bearing water supply line to maintain it.

3.3.4.8 Fill the LDCV with $\leq 200^{\circ} \mathrm{F}$ hot water so that it is $22^{\prime}$ over the centerline of the discharge nozzle. Verify LDCV tank temperature is $\geq 170^{\circ} \mathrm{F}$.

3.3.4.9 Verify test set up is following Test setup as agreed to by TWRS and FFTF personnel. 


\section{HNF-SD-W151-RPT-003}

\section{REV 0}

\subsection{Mixer Pump Performance Demonstration}

3.4.1. Initial start up of the first mixer pump was at $100 \mathrm{rpm}$ with speed increased at the VFD at $100 \mathrm{rpm}$ increments up to a maximum speed of $1200 \mathrm{rpm}$ or just under the cavitation rpm. The initial start up rpm for the following mixer pumps were varied as shown by the test data. However, the speed had to be high enough so that the heat generated by the pump work would overcome the heat loss of the LDCV tank so the LDCV water temperature would rise to the designated test requirement temperature range.

3.4.2 All the parameters required in the test specification are recorded for each pump on data sheets as shown Section 8.1 appendixes at 15 minute intervals for the first two hours and 30 minute intervals thereafter throughout the test period.

3.4.3 A log book was kept throughout the duration of the test to record all offnormal occurrences and corrective actions taken by the Test Engineer.

3.4.4 The mixer pump will be operated continuously with no trips or intentional shutdowns for a minimum of six hours with LDCV water temperature of $190^{\circ} \mathrm{F}$. The mixer pump shall also be operated continuously with LDCV water temperature at $200^{\circ} \mathrm{F}$ for a minimum of one hour.

3.5 Approved Deviations to Test Specs and Statement of Work

Each deviation has been verbally requested and approved by TWRS and agreed to by FFTF during the course of the testing of the pumps. In some cases, FFTF verbally requested the deviation and it was approved by TWRS. Listed below are the deviations:

3.5.1 Operate Mixer pumps 90908-2 \& 90908-1 for 72 hour continuous hours in addition to the six hour run @ $190^{\circ} \mathrm{F}$.

3.5.2 Do not monitor the frequency of the VFD. The VFD's used for the mixer pumps were installed in the field prior to testing so FFTF's VFD was upgraded to test the $300 \mathrm{hp}$ mixer pumps.

3.5.3 The LDCV tank (tank bulk) vibrations were extremely low and only recorded periodically throughout the initial test of Mixer Pump 90908-2.

3.5.4 Lower Pump /Pump Bowl vibrations (Casing Vibrations) were only recorded during testing of Mixer Pump 90908-2. Readings transmitted to the multimeters ranged between 10-20 mA constantly. This made it impossible for a individual recording data to lock in on a number and provided no useful data for an evaluation of the Pump Bowl vibrations.

3.5.5 Upper Pump/Pump Bearing Vibrations (Motor Vibrations) were only recorded during testing of mixer pump 90908-2. The numbers recorded were so low they were not deemed necessary for the other two mixer pump tests.

3.5.6 Pump column/column water temperature was recorded 
HNF-SD-W151-RPT-003

REV 0

3.5.7 Suggested heat rate increase of LDCV tank temperature be approximately $2^{\circ} \mathrm{F} / \mathrm{hr}$.

\subsection{TEST RESULTS}

\subsection{Test \#1 - Mixer Pump 90908-2}

\subsubsection{Pre-existing conditions}

Prior to starting the initial demonstration test. The time and budget to prepare the MASF facility to supply Hot Water to the LDCV and to provide a method of draining and bleeding water from the LDCV were of concern.

It was determined by FFTF and TWRS Project W-151 Representatives that the performance demonstration test could be performed without a hot water system using the work generated by operating the Mixer Pump for heat. FFTF performed a calculation which demonstrated that it would take the 300 HP Mixer Pump operating @ $1050 \mathrm{rpm} \approx 37$ hours to heat 12,720 gallons of water to $200^{\circ} \mathrm{F}$ from $70^{\circ} \mathrm{F}$.

The water in the LDCV had been there from a previous pump demonstration test on the 101SY Hydrogen Mitigation Pump. When filled for this test, there was no mechanism for draining the LDCV. Provisions to remove the bleed water from the LDCV tank for demonstration testing were limited because the bleed pipe protruded through the top of the LDCV plate. Meanwhile the 400 Area was in the process of permitting their process sewer effluent stream and questions existed if we could drain the existing water from the LDCV to the process sewer. Therefore, it was agreed between FFTF and Project W-151 that a dual path course would be taken so mixer pump testing could proceed. The first path was to proceed ahead with the first mixer pump test in the LDCV using the existing water in the tank. The second path was to obtain a temporary permit from the Washington State Department of Ecology to drain the existing water from the LDCV to the 400 Area process sewer so new clean water could be utilized for testing.

\subsubsection{Initial Demonstration Test}

The initial demonstration test began on 11-08-95. The pump was started at a speed of $100 \mathrm{rpm}$. The speed was then increased to 400 rpm and incremented upward in $100 \mathrm{rpm}$ increments every $1 / 2$ hour up to the maximum $1200 \mathrm{rpm}$. 


\section{HNF-SD-W151-RPT-003 \\ REV 0}

A vibration monitor was connected to the bottom of the LDCV tank to assist testing personnel in determining if or when mixer pump cavitation became evident. Throughout the startup, the in-line and $90^{\circ}$ accelerometers varied between 10-20 mA @ 1200 rpm. This eliminated part of the mechanism for determining pump cavitation. To improve these readings, buffers, a data sampler with averaging or less sensitive accelerometers would be required.

Initial LDCV tank temperature was $65^{\circ} \mathrm{F}$. With the mixer pump operating at $1200 \mathrm{rpm}$ continuously, the LDCV temperature rose to $122^{\circ} \mathrm{F}$ after 25 hours of continuous operation.

The Column water flow started out at $120 \mathrm{cc} /$ hour and remained constant as shown in the test data of Appendix 1 . After 18 hours of operating time, the column water flow dropped $40 \mathrm{cc} / \mathrm{hour}$ with a LDCV tank temperature at $105^{\circ} \mathrm{F}$. This flow remained for $6 \frac{1}{2}$ hours. The column water flow then dropped to zero as indicated on the bearing water flow meter. The LDCV tank temperature was $120^{\circ} \mathrm{F} .30$ minutes later with the LDCV tank temperature at $122^{\circ} \mathrm{F}$ and the seal water flow at zero, FFTF testing personnel shut the Mixer Pump off and shut down the test until consultation with TWRS Project Engineers and LPI Engineers took place to determine the cause of the water flow problem.

The mixer pump was started again on 11-10-95 at 400 rpm's and increased to $800 \mathrm{rpm}$ in an effort to establish flow. No flow was established so after 12 minutes of operation, it was shutdown. The LDCV tank temperature was $102^{\circ} \mathrm{F}$ although some discreprency was noticed when the bleed system was operated and the outlet temperature of the LDCV tank water was $132^{\circ} \mathrm{F}$. This raised suspicion that the LDCV tank temperature could have been $157^{\circ} \mathrm{F}$ before the initial mixer pump test was aborted.

Following a nine day period with bearing water pressure maintained on the mixer pump column, the bearing water flow meter read $120 \mathrm{cc} / \mathrm{hour}$ indicating flow through the lower seal had been re-established at some time. The LDCV tank temperature was $90^{\circ} \mathrm{F}$ although the outlet temperature gauge on the bleed system after operation read $119^{\circ} \mathrm{F}$.

On 11-14-95, TWRS Project personnel agreed with FFTF Engineering to shutdown the initial testing of Mixer Pump 90908-2. The mixer pump was removed from the LDCV and transferred onto the shipping/storage cradle. The lower mechanical seal manufacturer (John Crane Co.) determined there could be a potential design problem with the upper segmented bushing (See Section 8.2.3) of the lower mechanical seal 


\section{HNF-SD-W151-RPT-003 \\ REV 0}

assembly. This bushing (Part No. 31) is aiso known as the disaster bushing, and appeared to be limiting flow.

Disassembly of the mixer pump components proceeded in order for the mixer pump removal from the LDCV back to the shipping cradle.

The lower pump assembly was removed by FFTF craftsman with the assistance of LPI representative (Michael T. McHale). He provided four guide pins so the hub disc could be properly removed without damaging the impeller sleeve bushing that is made out of glass. Next the lower mechanical seal was removed and the LPI representative hand carried it back to John Crane for a design evaluation.

\subsubsection{MASF Facility Upgrades}

Since the lower mechanical seal evaluation and redesign were scheduled for approximately 8-10 weeks, TWRS authorized FFTF to: 1) establish LDCV tank temperature from the existing temperature probes on the LDCV insulated side walls instead of the thermowell at the bottom of the tank. 2) Modify the MASF Hot Water System so that hot water could be provided to the LDCV and 3)Establish a drain/bleed line from the LDCV to the 400 Area process sewer. TWRS also required the mixer pump be started in $2170^{\circ} \mathrm{F}$ LDCV tank water in all future mixer pump tests. To support the bleed/drain line upgrade, the LDCV was drained with water using the newly purchased centrifugal pump and temporary hoses authorized by a temporary process sewer drain permit. Draining was completed on 11-30-95 the day the temporary process sewer drain permit expired. This also allowed the LDCV to be washed with most of the iron oxide removed off the inside of the tank. The general upgrades to the MASF facility are discussed in the following substeps:

\subsubsection{LDCV Bleed/Drain Water System}

The existing bleed line routed out the top of the LDCV connected to the air operated diaphragm pump were abandoned. A small centrifugal pump routed from the bottom of the LDCV to a floor penetration on the MASF high bay connecting to the process sewer was installed with a three way control switch. One switch at the floor penetration west of the LDCV in the MASF high bay area and the other switch next to the pump near the bottom of the outside of the LDCV. This enabled efficient bleed water operation from the LDCV tank for heat removal purposes during Mixer Pump testing and 
HNF-SD-W151-RPT-003

REV 0

provided FFTF MASF Operations a mechanism to easily drain the LDCV tank of water used for testing purposes.

\subsubsection{Hot Water System}

The existing MASF Hot Water Tank (HX-2001) and associated piping feeding the lower portion of the LDCV had never been put into service and was blanked off from the LDCV. This system was modified, connected and acceptance tested by FFTF so $\geq 170^{\circ} \mathrm{F}$ water could be supplied to the LDCV prior to starting the Mixer Pump in order to meet the test specification requirements. HX-2001, the $1800 \mathrm{KW}$ Hot Water Heater presented many challenging leaks around the heating elements mandating replacement of some during start up and operation.

\subsubsection{Feed Water System}

The Feed Water line was modified slightly to utilize the process water supply just below the floor penetration to the west of the LDCV. This enabled flexibility by MASF operations and pump testing personnel to use process water without impacting the schedule of the mixer pump test or MASF facility operations work.

\subsubsection{LDCV Tank Water Temperature Indication}

The thermocouple installed in the bottom of the LDCV to initially read LDCV water tank temperature proved to be grossly inaccurate. Also, the existing thermocouples strapped under insulation around the LDCV tank at various locations and elevations were routed to three analog meters that were difficult to read and subject to large parallax errors. Therefore, the three existing analog meters were routed to a digital meter installed in the MASF control room for the official reading of the LDCV tank water temperature indication.

\subsubsection{Test Data Comparison with LPI Testing}

Comparing initial test data (Appendix 8.1.1) and LPI pump test data some discrepancies were identified along with some expected differences. Listed below are the discrepancies:

1) MASF stator temperature and LPl's thrust temperature were identical 


\section{HNF-SD-W151-RPT-003 REV 0}

2) MASF vibrations were recorded in units of IN/SEC, LPI's were in mils.

3) LPI never recorded column flow past the lower mechanical seal

It was determined that LPI's thrust temperature was actually their stator temperature, it had just been recorded in the wrong category. The vibration units can be converted and compared if necessary and LPI did not continously record the lower mechanical seal water flow on their test data sheets. They recorded it a couple of times at $130^{\circ} \mathrm{F}$ tank temperature back at their facility and it was approximately $40 \mathrm{cc} / \mathrm{hour}$.

\subsubsection{Lower Mechanical Seal Design Flaw}

Following a reevaluation of the seal design by John Crane, the mechanical seal manufacturer, the full dog screws (Part Number 37) were found to be worn. Stainless to stainless steel interference with the housing was also found. John Crane Seal acknowledged a design flaw because they did not take into account the column water supply pressure and the 50 psi head pressure put on the column during operation. The mixer pump was dissembled and the mechanical seal removed as shown in photos \#4 and \#5 of Section 8.3. Mixer pumps 90908-1 which is waiting to be tested also had this type of lower mechanical seal with the defective parts.

\subsubsection{Column Water Flow through the Lower Mechanical Seal}

The mechanical seal drawing (See Section 8.2.3) states that the design flow rate through the seal is $250 \mathrm{cc} /$ hour. (mi/hour are the same as cc/hour). FFTF requested that TWRS Project provide a minimum mechanical seal flow rate so we would know when to shut down the mixer pump due to a inadequate flow through the seal that would possibly cause damage to seal. A minimum flow rate through the lower mechanical seal was not established because it could not be determined why the flow indication dropped to zero during our initial pump test of $90908-2$ and it is impossible to measure.

\subsubsection{Turntable Installation}

Mixer Pump 90908-1 was the only pump where the turntable was shipped separatedly from LPI. The turntable was installed with the mixer pump horizontal as shown in Photo \#3 in Section 8.3. The rotek bearing bolts that attached the turntable to the mixer pump were torqued to $390 \mathrm{ft}-\mathrm{lbs}$. 


\section{HNF-SD-W151-RPT-003 \\ REV 0}

\subsubsection{Lower Mechanical Seal Installation}

Though FFTF Craft and Engineering had no prior experience on installing the lower pump assembly and lower mechanical seal installation, it was determined that a special procedure was required to properly document our work and to receive the TWRS Project Engineer and LPI Engineer agreement prior to beginning the job. FFTF authored the special procedure titled "Lower Mechanical seal installation \& Lower Pump Re-assembly Procedure for Project W-151 Lawrence 300 HP Mixer pumps 90908-1 \& 90908-2" with TWRS Project Engineer approval. Photo \#6 of Section 8.3 show the final re-assembly of the new mechanical seal and lower pump assembly.

\subsubsection{Performance Demonstration}

The second and final performance demonstration test began on 04-0996. Before the mixer pump was started, the lower seal water flow was < $34 \mathrm{cc} /$ hour indicating that flow does exist but it was off scale on the low side of the flow meter. The mixer pump was started at $750 \mathrm{rpm}$ with the LDCV tank temperature at $172^{\circ} \mathrm{F} .30$ minutes later, with speed increased to $800 \mathrm{rpm} 1 / 2$ hour later with upper seal inlet pressure (column pressure) at $48 \mathrm{psig}$. Note that the column pressure relief valve is set at 60 psig to prevent overpressurization of the pump column water.

Seven hours into the test, the upper and lower bearing temperature readings are well below normal, therefore, the test data sheet in Section 8.1 is shaded gray where the temperature readings are believed to be inaccurate values. Testing continued since these temperatures had remained stable on the initial demonstration test and when compared to LPI's temperature they were also very similar.

The LDCV tank temperature stabilized at $180^{\circ} \mathrm{F}$ with the mixer pump at $800 \mathrm{rpm}$. The rpm was increased to $850 \mathrm{rpm}$ and then backed off to $825 \mathrm{rpm}$ so as not to exceed the $2^{\circ} \mathrm{F} /$ hour heat up rate. With the LDCV tank temperature at $189^{\circ} \mathrm{F}$, the mixer pump speed was increased to $950 \mathrm{rpm}$. At 9:35AM on 04-10-96, the LDCV tank temperature indicated $190^{\circ} \mathrm{F}$ beginning the six hour run $\geq 190^{\circ} \mathrm{F} \mathrm{LDCV}$ tank water temperature. The LDCV tank temperature increased to $200^{\circ} \mathrm{F}$ in a matter of five hours. The mixer pump speed was increased to 1050 rpm during the one hour required run @ 200\% F LDCV tank water temperature. After one successful hour of mixer pump operation at $200^{\circ} \mathrm{F} \mathrm{LDCV}$ tank water, the mixer pump rpm was decreased to 800 $\mathrm{rpm}$ for the remaining duration of the 72 hour test run. This completed 


\section{HNF-SD-W151-RPT-003 \\ REV 0}

the requirement of a six hour continuous mixer pump operation with a LDCV tank temperature $\geq 190^{\circ} \mathrm{F}$ with one hour of operation @ $200^{\circ} \mathrm{F}$ :

The seal water flow (pump column flow) remained above zero but off scale low ( $(34 \mathrm{cc} /$ hour). Seven hours after the mixer pump speed had been decreased to $800 \mathrm{rpm}$, the lower seal water flow rose to off scale high on the bearing water flow meter ( $335 \mathrm{cc} /$ hour) with the LDCV tank temperature still at $200^{\circ} \mathrm{F}$. The upper seal inlet pressure had dropped to 42 psig. The bearing water supply to the upper seal inlet was isolated and the mixer pump was shutdown for an evaluation.

At this time, the flow meter's scale was changed from $35-335 \mathrm{cc} /$ hour to $120-1200 \mathrm{cc} / \mathrm{hour}$. With the pump shut down, the bearing water was established on the upper seal inlet and seal water flow indicated 750 $\mathrm{cc} /$ hour. The mixer pump was started and operated at $800 \mathrm{rpm}$. The seal water flow dropped to $300 \mathrm{cc} /$ hour. After six minutes of operation, the mixer pump was shutdown again. The seal water flow returned to $750 \mathrm{cc} /$ hour. LDCV tank temperature was at $195^{\circ} \mathrm{F}$.

The mixer pump was started up and shut down several times because of the inconsistencies observed on the seal water flow. The seal water flow would fluctuate from zero to $650 \mathrm{cc} /$ hour. In the mean time, as the LDCV tank temperature dropped, so did the seal water flow.

After the LDCV tank temperature had cooled down to $138^{\circ} \mathrm{F}$, the mixer pump was started and operated at $800 \mathrm{rpm}$. The seal water flow had returned to $\langle 35 \mathrm{cc} /$ hour until the pump column was vented. Flow increase to $>280 \mathrm{cc} /$ hour for about $11 / 2$ hours and then returned to < 35 cc/hour.

\subsubsection{Lower Mechanical Seal Water Flow Characterisfics}

After analyzing three characteristics of the test data during the test, FFTF determined that we were not accurately measuring the seal water flow. The first characteristic was the expansion cavities built inside the column to allow for heat up of the water. As the LDCV tank temperature increases, so does the pump column temperature and pressure. The second characteristic was the heat input caused by the rotating mixer pump shaft and the rising temperature of the LDCV tank water temperature. This caused temperatures and pressures to rise inside the column. The third characteristic was the pressure build up inside the column and the constant need to vent it off during the test. The test pressure safety valve protecting 


\section{HNF-SD-W151-RPT-003}

REV 0

overpressurization of the pump was set at $60 \mathrm{psi}$ and the pressure recommended that we maintain on the column was 50 psi.

When the pump column temperature and pressure are rising, part of the water volume in the mixer pump column is increasing because the expansion cavity air is being compressed and the other part of the water is flowing past the seal. If the mixer pump column pressure and the upper seal inlet pressure were at equilibrium, then the flow could be accurately measure by the test flow meter. This is why the flow meter indicates a very low to zero reading when we are operating the pump and providing heat input into the mixer pump column water cavity. There are three 15 gallon expansion cavities inside the mixer pump column that would take a couple of months to fill up and the rate MASF filled it.

The work generated by the rotating mixer pump shaft and the heat transfer from the LDCV tank water elevated temperature cause pressure to rise in the column as mixer pump operation continues and LDCV tank temperature increases occur.

The pressure in the mixer pump column exceeds the inlet water pressure, minimum to no flow is observed on the inlet flow meter to the mixer pump column water. Once column pressure drops below supply pressure, inlet to column flow begins and replaces water flow through the lower seal. This is evident observing the test data sheets.

It was determined that inadequate instruments were available for lower seal water flow to be accurately measured during the test. Two changes were made during the test to determine if the lower seal flow could be measured with the existing instruments over an entire testing period. The first change was to reroute the relief line from the PSV to a 5 gallon polyglass bucket. The second change was to install a auxiliary flow meter that totalized the flow. If the flow was totalized from equilibrium between the inlet upper seal water piping to the Mixer Pump Column and the Mixer Pump column water area at the beginning of the test and allowed time to cool back down following the test to equilibrium, then lower seal water flow could be calculated. Since these changes were implemented half way through the testing period, this method could not be 


\section{HNF-SD-W151-RPT-003 \\ REV 0}

used for calculating the actual lower seal water flow but data does indicate that there was flow though the lower seal.

\subsubsection{Post Lower Seal Decay Pressure Test}

Since lower seal water flow could not be accurately measured, LPI agreed to a decay pressure test and set a limit of $\leq 2$ psi drop @ 50 psi pressure for a two minute period. This verified that the seal had maintained an adequate seal following the demonstration and performance test of the Mixer Pump in the LDCV. The test was performed and successfully passed. This was performed as a pretest and post-test for a comparison basis.

\subsubsection{Mixer Pump Removal \& Restoration}

The electric motor and instrumentation were removed from the mixer pump. The mixer pump was removed from the LDCV via a critical lift procedure and transferred to the horizontal position on the shipping/storage cradle. All the components and instruments installed in Section 3.3.1 were removed. The mixer pump, electric motor and instrumentation were secured for shipment to the 200 Area.

\subsection{Test \#2 - Mixer Pump 90908-1}

\subsubsection{Prerequisites to Testing}

This mixer pump was delivered without the turntable installed. Step 4.1.7 installed the turntable during the testing of Mixer Pump 90908-2. The lower mechanical seal in both mixer pumps 90908-1 \& 2 were defective and required refurbishing as stated in step 4.1.5. Since the turntable was delivered apart from mixer pump 90908-1, it was installed at this time so the so the lower pump assembly and the mechanical seal could be removed and replaced prior to testing. Step 4.1.8 installed the new lower mechanical seal in Mixer Pump 90908-1.

\subsubsection{Lower Seal Decay Pressure Test}

The lower seal was decay pressure tested before testing of the Mixer Pump with filtered water @ 50 psi for 2 minutes allowing no more than a 2 psi pressure drop. The lower mechanical seal successfully passed the test and was used as a baseline for post tests. 


\section{HNF-SD-W151-RPT-003 \\ REV 0}

\subsubsection{Pre-existing conditions}

The 400 Area effluent stream was in the process of being permitted with he Washington State Department of Ecology. FFTF's temporary permit had expired on 11-30-96 that allowed draining of the LDCV. The permanent permit was scheduled to be completed in the mid summer and a temporary permit for the draining of the LDCV could not be obtained in the time required to meet the demonstration test schedule. Therefore, TWRS Project personnel agreed that the existing water from mixer pump 90908-2 demonstration test would be used without prior heating for this mixer pump performance demonstration. The value added for the motor (lower, upper and thrust) and casing (axial/inline and $90^{\circ}$ ) vibration readings taken on the first demonstration test were evaluated and determined not to be necessary for future runs on this type of mixer pump. Therefore they were deleted from the data sheets.

\subsubsection{Performance Demonstration}

The performance demonstration began on 05-20-96. A new flow totalizer had been installed during the last demonstration run which measured the flow in $\mathrm{cc} / \mathrm{min}$ and totalized the flow in $\mathrm{cc}$. At the request of FFTF and agreed by TWRS Project personnel, the upper seal inlet pressure was reduced to $30 \mathrm{psi}$ to reduce the change in pressure between column and supply pressure during the performance run.

Before the mixer pump was started, the seal water flow was 0 . The mixer pump was started at $100 \mathrm{rpm}$ with the LDCV tank temperature at $91^{\circ} \mathrm{F}$. The speed was increased up to $1000 \mathrm{rpm}$, then reduced to 850 $\mathrm{rpm}$ for about 9.5 hours. Finally, the speed was increased to $950 \mathrm{rpms}$ until the LDCV tank heated up to $198^{\circ} \mathrm{F}$. It took the mixer pump @950 rpm's 47.25 hours to heat up the LDCV tank water from $110^{\circ} \mathrm{F}$ to $198^{\circ} \mathrm{F}$.

At 11:45 PM on 05-22-96, the LDCV tank temperature indicated $190^{\circ} \mathrm{F}$ beginning the six hour run $\geq 190^{\circ} \mathrm{F}$ LDCV tank water temperature. The LDCV tank temperature increased to $199^{\circ} \mathrm{F}$ in a matter of six hours. The mixer pump speed was increased to $1020 \mathrm{rpm}$ during the one hour required run @ $200^{\circ} \mathrm{F} \pm 1^{\circ} \mathrm{F} L D C V$ tank water temperature. After one successful hour of mixer pump operation at $199^{\circ} \mathrm{F} L D C V$ tank water, the Mixer Pump rpm was decreased to 800 rpm for a short 


\section{HNF-SD-W151-RPT-003 \\ REV 0}

duration and then decreased again to $750 \mathrm{rpm}$ for the remaining duration of the test.

\subsubsection{Seal Water Flow Characteristics}

The seal water flow (pump column flow) remained approximately zero throughout the test. However, halfway through the run the totalized flow was recorded on the test data sheets indicating a $2 \mathrm{cc} /$ hour average flow was being recorded throughout the duration of the 72 hour run. After the mixer pump was shutdown for 15.5 hours (overnight), flow was observed@288 cc/hour on the flow meter/totalizer and accepted by TWRS Project Personnel. This is makeup of flow that had gone through the lower seal during operation but was hidden by the mixer pump column expansion cavities due to the drop in temperature after operation had ceased.

\subsubsection{Post Lower Seal Decay Pressure Test}

The lower seal was decay pressure tested after the mixer pump completed its performance run with filtered water at 50 psi for 2 minutes allowing no more than a 2 psi pressure drop. The lower mechanical seal successfully passed the test with TWRS Project personnel and Department of Energy Site Representatives visually observing.

\subsubsection{Mixer Pump Removal \& Restoration}

The electric motor and instrumentation were removed from the mixer pump. The mixer pump was removed from the LDCV via a critical lift procedure and transferred to the horizontal position on the shipping cradle. All the components and instruments installed in Section 3.3.1 were removed. The pump column was left pressurized until removal if water existed in the LDCV. The mixer pump, electric motor and instrumentation were secured for shipment to the 200 Area.

\subsection{Test \#3 - Mixer Pump 90908-3}

\subsubsection{Prerequisites to Performance Demonstration}

This mixer pump was delivered with the turntable and the new type lower mechanical seal installed.

\subsubsection{Lower Seal Decay Pressure Test}




\section{HNF-SD-W151-RPT-003 REV 0}

The lower seal was decay pressure tested before testing of the Mixer Pump with filtered water @ 50 psi for 2 minutes allowing no more than a 2 psi pressure drop. The lower mechanical seal successfully passed the test.

\subsubsection{Pre-existing conditions}

No pre-existing conditions were present with the MASF facility or with the Mixer Pump. The permanent permit had been issued to FFTF from the Washington State Department of Ecology for the 400 Area effluent stream which included provisions to periodically drain the LDCV tank throughout the year in support of Mixer Pump Performance Demonstration at MASF.

The only difference between this mixer pump and the other two mixer pumps was that TWRS Project personnel verbally eliminated the 72 hour continuous operation requirement.

\subsubsection{Performance Demonstration}

The performance demonstration test began on 10-16-96. The upper seal inlet pressure was again reduced to 30 psi to eliminate the column venting during the test. This was a carryover change from mixer pump 90908-1.

Before the mixer pump was started, the seal water flow was $40 \mathrm{cc} / \mathrm{hour}$. FFTF was successful at obtaining a LDCV tank temperature of $181.7^{\circ} \mathrm{F}$ prior to starting the mixer pump. The mixer pump was ramped up to $950 \mathrm{rpm}$ and operated for approximately two hours. Speed was then increased to $1100 \mathrm{rpm}$ for one hour because the LDCV tank temperature increased $\left\langle 2^{\circ} \mathrm{F} /\right.$ hour. Speed was then reduced to 1050 rpm because the LDCV tank temperature rise was $>2^{\circ} \mathrm{F} /$ hour. This rpm was maintained for 1.5 hours until a LDCV tank temperature increased to $190^{\circ} \mathrm{F}$. At this point, the six hour run with a LDCV tank temperature $2190^{\circ} \mathrm{F}$ was started and the rpm was reduced to 950 . Over the next 6.8 hours, the LDCV tank temperature increased to $199^{\circ} \mathrm{F}$. This completed the test specification requirement of mixer pump operation $2190^{\circ} \mathrm{F}$ for six hours. At this point, the temperature rise was approximately $.5^{\circ} \mathrm{F} /$ hour, so the mixer pump speed was increased to $1000 \mathrm{rpm}$ for the remainder of the test to raise the LDCV tank temperature to $200^{\circ} \mathrm{F}$. Following, the one hour test run @ $200^{\circ} \mathrm{F}$ was performed and passed. The speed was maintained at $1000 \mathrm{rpm}$ for the duration of the test and the mixer pump operated without a shutdown. The mixer pump operated successfully with the LDCV tank temperature @200 $\mathrm{F}$ for the duration of the test. 


\section{HNF-SD-W151-RPT-003}

\section{REV 0}

\subsubsection{Seal Water Flow Characteristics}

The lower seal water flow (pump column flow) remained approximately zero throughout the test through shutdown. After shutdown when the LDCV tank temperature cooled down to $167.8^{\circ} \mathrm{F}$, flow became evident on the flow meter as expected. The totalized flow through the feed system was recorded after the Mixer Pump was shutdown which indicated a slight amount of flow through the system prior to it being evident visually on the flow meter. FFTF elected to keep track of the lower seal water flow until equilibrium was reached between the column supply pressure and the mixer pump column pressure. Therefore following completion of the mixer pump test, the column seal water flow and pressure were left for a period of 8 days before equilibrium was achieved. From the test data sheets, the average lower seal water flow was calculated by taking the totalized flow amount and dividing it by the total number of operating hours. The average lower seal water flow was approximately $354 \mathrm{cc} /$ hour which is $\leq 500 \mathrm{cc} /$ hour required by the test specification but $\geq 120 \mathrm{cc} /$ hour expected flow.

\subsubsection{Post Lower Seal Decay Pressure Test}

The lower seal was decay pressure tested with filtered water @ 50 psi for 2 minutes allowing no more than a 2 psi pressure drop. The lower mechanical seal successfully passed the test .

\subsubsection{Mixer Pump Removal}

The electric motor and instrumentation were removed from the mixer pump. The LDCV has been drained of the water used for testing. The mixer pump is currently being stored in the LDCV until the MASF facility is needed for another mixer pump test.

\subsection{CONCLUSIONS AND RECOMMENDATIONS}

\subsection{Cavitation}

The Mixer Pump 90908-2 ran well with water in the LDCV even at the maximum rpm of 1200 . Cavitation was of concern initially but after running the mixer pump continuously for 21 hours @ a speed of 1200 $\mathrm{rpm}$, cavitation did not appear to be evident. Although the instrumentation to detect cavitation was less than adequate, a vibration monitor probe on the bottom of the LDCV tank was monitored along with auditory cavitation 


\section{HNF-SD-W151-RPT-003 \\ REV 0}

noises. The viscosity of the slurry in the tanks where the mixer pumps will be used is higher which could cause the mixer pump to cavitate at a lower rpm. If this is a concern for long term operation, a data sampler with averaging, a buffer or a less sensitive accelerometer should be installed at the pump bowl so mixer pump cavitation can be detected with accurate vibration instruments.

\subsection{Mixer Pump Motor Characteristics}

The recorded amps during the initial testing @ the mixer pump maximum speed of $1200 \mathrm{rpm}$ were still $25-32 \%$ lower than the expected range of 300-330 Amps. The amps were $46-49 \%$ lower than when compared to the expected range with the mixer pump operating at $1000 \mathrm{rpms}$. This could have been due to less friction from the thrust, column sleeve and impeller sleeve bearings than expected or from less friction than expected from the rotor core assembly and opposite and drive end bearing assemblies.

The voltage was $3 \%$ lower than the expected range with the mixer pump operating@1000 rpm. This value was close enough to say it operated as expected.

Another operating amperage difference could have been from using different VFDs with the FFTF VFD manufactered by Eaton was more efficient than the VFD provided that was manufactured by Reliance.

The motor frequency was not recorded during any of the mixer pump tests. The VFDs used by TWRS for the mixer pumps were manufactured by Reliance. TWRS wanted to install them in the permanant location prior to performing the testing in MASF, so TWRS provided funding to upgrade the existing VFD manufactured by Eaton from $175 \mathrm{HP}$ to $400 \mathrm{HP}$. The Eaton variable frequency data is different than the Reliant variable frequency data. Therefore, it was agreed by TWRS Project Personnel and FFTF that recording the frequency for these tests would not be of any value and it was deleted from the parameters that were required to be recorded.

\subsection{Pump Vibration}

The test specification requirements stated that upper and lower vibration points needed monitoring throughout the test but no expected range or maximum values were provided. In addition, no specific test locations were provided for the upper and lower vibration monitoring points. The final performance demonstration run on mixer pump 90908-1 recorded the 


\section{HNF-SD-W151-RPT-003 \\ REV 0}

final performance demonstration run on mixer pump 90908-1 recorded the axial, in-line and $90^{\circ}$ vibration readings just above the pump bowl. The accelerometers varied between 10-20 mA consistently so that a accurate value was impossible to measure without the improvements that were recommended earlier. These readings would be essential for tank operation to monitor whether the mixer pump was cavitating after it was installed in a 200 Area Tank. To improve these readings, a buffer, data sampler with averaging or less sensitive accelerometers would be required. We monitored the LDCV tank for vibration during the initial test of Mixer Pump 90908-2 and very low readings were recorded. The bottom outside of the LDCV was accessible to FFTF for monitoring the noise level and no abnormal cavitation type noises were noted on the logs or recorded in the data sheet. More emphasis should be placed on lower pump vibration monitoring instrumentation. The viscosity of the 200 Area Tank fluid will probably be much higher than water, which would increase the probability of cavitation to occur.

\subsection{Pump Column Temperatures}

The pump column temperatures were not specifically recorded during the test because there was not a thermowell connection to install a temperature indicator for accurate recording. However, upper and lower column water temperatures were recorded in the data sheets. The upper column temperature was a probe inserted into the column fill line at the top of the mixer pump. The lower column temperature was a temperature probe secured to the outside of the mixer pump column ten feet below the turntable. These temperatures only give an indication what the mixer pump column temperature is doing, not the actual value of the pump column temperature. Thermowells should be installed near the pump casing at the bottom of the pump column and at the top of the pump column to accurately track the column temperatures for testing and during operation of the Mixer Pump in the 200 Area tanks.

\subsection{Motor Temperatures}

The motor winding temperatures (recorded in the Test Data Sheets as "Stator") were $137^{\circ} \mathrm{F}$ with the LDCV tank temperature at $200^{\circ} \mathrm{F}$. This was slightly above the expected range of $120^{\circ} \mathrm{F}$. If the 200 Area tank temperatures average around $150^{\circ} \mathrm{F}$, the motor winding temperature hovered between $120-125^{\circ} \mathrm{F}$ which falls near the expected range. The motor winding temperature was not recorded for the Mixer Pump 909081 , but indications from Mixer pumps 90908-2 and 90908-3 were close to the expected range and $32 \%$ less than the maximum value of $200^{\circ} \mathrm{F}$ at the peak temperatures of the LDCV tank. 


\section{HNF-SD-W151-RPT-003}

REV 0

\subsection{Lower Seal Water Flow (Pump Column Flow)}

This parameter was the most visible during all of the performance demonstration testing. The design leakage through the seal was 250 $\mathrm{ml} /$ hour (same as $\mathrm{cc} /$ hour) and the expected range from the test specification was $125 \mathrm{ml} /$ hour with a maximum of $500 \mathrm{ml} /$ hour. FFTF was never able to accurately measure flow throughout the entire testing of the three Mixer pumps because of the lack of proper instrumentation and no access to lower seal discharge.

The first lower mechanical seal failed after flow through it dropped to zero part way through the test. The seal was then removed and sent back to the seal manufacturer for an evaluation. The full dog set screws were found to be worn along with interference in the seal housing. The seal manufacturer did not take into account the thermal growth during operation. A new lower mechanical seal was instalied via a special procedure approved by LPI, TWRS Projects and FFTF.

As the second phase of the first test resumed, the lower seal water flow remained low (as in off scale low) in general during the duration of the test. Water flow through the lower seal was not observed until the mixer pump was shutdown and cooldown was initiated on the mixer pump column water. As stated earlier, the heat being generated by the mixer pump shaft rotating inside the column and the heat transfer from the LDCV tank temperature caused pressure to rise in the mixer pump column. When the pressure in the column exceeded the upper seal inlet water pressure, the flow indication on the upper seal inlet water line went to approximately zero and remaind there until column pressure dropped just below supply pressure on cooldown.

The water in the mixer pump column is a dynamic system when it is operating. After the characteristics of the lower seal water flow were determined midway through the 90908-2 final demonstration and performance run, all three Mixer pumps operating characteristics were very similar. The method we used to determine the lower seal water flow was not accurate. All the lower seal water flow recorded values did was verify the characteristics of the expansion cavities in the pump column and established that they maintain flow through lower seal while column pressure is above supply pressure coupled with the heat generated by the mixer pump shaft rotation and the heat transferred from the LDCV tank into the pump column. 


\section{HNF-SD-W151-RPT-003 \\ REV 0}

FFTF did measure the flow through the seal with the existing instrumentation after the flow totalizer was installed on Mixer Pump 90908-3. This was performed using two functions: 1) Record the total flow when the system was at equilibrium before the mixer pump was started and totalizing it until the system was at equilibrium after mixer pump operation was complete, 2) do not vent the pressure to keep the 60 psi pressure safety valve from venting, but let the PSV vent during the test into a closed container so the volume could be measured. The second function did not apply to the mixer pump 90908-3 test because the pressure safety valve on the upper inlet seal water did not vent during the testing period. This method yielded an average lower seal water flow of $354 \mathrm{cc} /$ hour which is $\leq 500 \mathrm{cc} /$ hour maximum but $\geq 120 \mathrm{cc} /$ hour expected range of flow per the test specifications.

The lower seal decay pressure test was chosen in favor of using the totalized flow and waiting for the systems to return to equilibrium (due to TWRS scheduling restraints). Only a post lower seal decay pressure test was performed on 90908-2 Mixer Pump because the decision to perform the test did not occur until midway through the testing. Mixer pumps 90908-1 \& 90908-3 both received lower seal decay pressure test before and after each performance and demonstration to verify the seal did not receive damage during the testing period.

It is suggested that some type of instrument be installed so the lower seal water flow can be monitored continually throughout the operating period. If this is not a possibility, then the mixer pump column pressures should be monitored continuously near the top of the column and at the bottom of the column to ensure flow is going through the lower seal.

\subsection{LDCV Tank Water Temperature}

The LDCV tank temperature was used to operate the mixer pump in the expected range of the pump column temperatures. Each mixer pump was started at a different LDCV tank temperature because of circumstances explained in Section 4. Mixer pump 90908-2 was started @ $172^{\circ} \mathrm{F} \mathrm{LDCV}$ tank temperature, 90908-1@91 ${ }^{\circ} \mathrm{F}$ and 90908-3@181.7 $\mathrm{F}$. All the mixer pumps performed as expected during the six hour continuous operation @ $\geq 190^{\circ} \mathrm{F}$ LDCV tank temperature and the one hour continuous operation @ $200^{\circ} \mathrm{F} \pm 1^{\circ} \mathrm{F} \mathrm{LDCV}$ tank temperature. Elevated temperatures of the fluid surrounding the mixer pump column will not affect start up or continued operation of the mixer pumps as a result of this performance demonstration run. 


\section{HNF-SD-W151-RPT-003}

REV 0

\subsection{DISPOSITION OF TEST ITEMS}

6.1 Transfer of Pumps to TWRS

Mixer pumps 90908-2 and 90908-1 were transferred to a truck via the signed off Critical Lift Procedure and transported to the 200 Area for installation following completion of the test.

\subsection{Mixer pump Storage}

Mixer pump 90908-3 is a designated spare which requires adequate storage until needed in one of the Tanks. No place on site was found to be adequate, so it was decided that the pump would be stored in MASF. Since no other pump testing was going to occur in the LDCV until late fall or early winter of 1997, Mixer pump 90908-3 is being stored in the LDCV test stand until the MASF facility needs to test another mixer pump. When that occurs, the mixer pump will be removed from the LDCV to the shipping/storage cradle for storage or for shipment to the 200 Area. However, monthly rotations of the pump and motor shafts are being performed while in storage at MASF.

\subsection{REFERENCES}

\subsection{Work Packages}

7.1.1 4A-95-081/M - Test 300HP Mixing Pump (S/N 90908-2) in LDCV

7.1.2 4A-95-080N - Test 300HP Mixing Pump (S/N 90908-1) in LDCV

7.1.3 4A-95-118N - Test 300HP Mixing Pump (S/N 90908-3) in LDCV

7.2 Test Specification

WHC-SD-W151-TS-001, Rev 0, Mixer pump Test Specification for Project W151

\subsection{Statement of Work}

8K520-95-004, Statement of Work for Project W-151 Mixer pump Performance. Demonstration at MASF

\subsection{APPENDIXES}

8.1 Mixer pump Test Data Sheets (Attached) 
REV 0

8.1.2 300 HP MIXER PUMP 90908-2 PERFORMANCE DEMONSTRATION TEST DATA SHEETS

8.1.3 300 HP MIXER PUMP 90908-1 PERFORMANCE DEMONSTRATION TEST DATA SHEETS

8.1.4 300 HP MIXER PUMP 90908-3 PERFORMANCE DEMONSTRATION TEST DATA SHEETS

8.2 Sketches and Drawings (Attached)

\subsubsection{SKETCH OF 300 HP MIXER PUMP TEST SETUP}

This sketch illustrates the setup of the test and it correlates the numbered columns on all the test data sheets for each pump and identifies where the data was obtained. This sketch depictifies all the test data points obtained during each test. Some test data points were added but more were deleted as testing of the pumps progressed and it was learned which data was meaningful.

The thickest dark line is the flowpath used for the filter seal water through the flow meter/totalizer from the MASF process water system during each test. The FE flow meter/totalizer used on the last two pump tests recorded digitally the flow in $\mathrm{cc} / \mathrm{min}$. The Fl flow meter used on the initial and retest of the first pump was recorded in cc/hour.

8.2.2 Elevation of 6" Vertical Line Shaft Bearing Pump

8.2.3 Lower Mechanical Seal Vendor Drawing

8.3 Photos (Attached)

\#1 EAST VIEW OF MIXER PUMP INSTALLATION INTO THE LDCV

\#2 SOUTH VIEW OF MIXER PUMP INSTALLATION INTO THE LDCV

\#3 INSTALLING THE TURNTABLE ON MIXER PUMP 90908-1

\#4 REMOVED PUMP CASING (TOP) AND HUB DISC (BOTTOM)

\#5 REMOVED SUCTION STRAINER/AGITATION RING (TOP) AND IMPELLER/SUCTION DISC (BOTTOM)

\#6 LOWER PUMP ASSEMBLY RE-INSTALLED WITH NEW MECHANICAL SEAL 


\section{HNF-SD-W151-RPT-003}

REV 0

8.4 MASF Pump Test Personnel

8.4.1 FFTF Engineering

Project Manager . . . . . . . . . . . . . . . . .JR Vincent

Mechanical Engineer . . . . . . . . . . . . . . Brian G. Berglin

Electrical Engineer. . . . . . . . . . . . . . . . Allen B. Brewer

8.4.2 FFTF Maintenance

Person In Charge. . . . . . . . . . . . . . . . John E. Cozad 
INITIAL 300 HP MIXER PUMP 90908-2 PERFORMANCE DEMONSTRATION TEST DATA SHEETS 400 AREA - MASF

\begin{tabular}{|c|c|c|c|c|c|c|c|c|c|c|c|c|c|c|c|}
\hline \multirow{2}{*}{\multicolumn{2}{|c|}{ onterrimo }} & \multicolumn{3}{|c|}{ Motor toads } & \multicolumn{2}{|c|}{$\begin{array}{c}\text { cesing Yibrations } \\
\text { (Hilitames) }\end{array}$} & \multicolumn{3}{|c|}{$\begin{array}{c}\text { Hotor Temperatures } \\
(1 F)\end{array}$} & \multicolumn{2}{|c|}{$\begin{array}{c}\text { Hotor Vibrations } \\
(I n / \mathrm{sec})\end{array}$} & \multirow{2}{*}{$\begin{array}{c}\begin{array}{c}\text { Columin water } \\
\text { Terporatures } \\
\text { (of) }\end{array} \\
\text { upper } \\
\text { (13) }\end{array}$} & \multirow{2}{*}{$\begin{array}{l}\text { Lowar scal } \\
\text { vater Pfiow } \\
\text { (se/mowr) } \\
(19)\end{array}$} & \multirow{2}{*}{$\begin{array}{l}\text { Locv Tank } \\
\text { Tempiotatura } \\
\text { ("F) } \\
(20)\end{array}$} & \multirow{2}{*}{$\begin{array}{c}\text { coov Tank } \\
\text { vibractions } \\
\text { (In/sos) } \\
\text { (21) }\end{array}$} \\
\hline & & \multirow{2}{*}{$\begin{array}{c}\text { volts } \\
\text { (1) } \\
0\end{array}$} & \multirow{2}{*}{$\begin{array}{c}\text { aros } \\
\text { (2) } \\
0\end{array}$} & \multirow{2}{*}{$\begin{array}{c}\text { (3) } \\
0\end{array}$} & \multirow{2}{*}{$\begin{array}{l}\text { Intine } \\
\text { (4) } \\
4.273\end{array}$} & \multirow{2}{*}{$\begin{array}{r}90^{\circ} \\
(5) \\
4.117 \\
\end{array}$} & $\begin{array}{l}\text { stator } \\
\text { (J) } \\
\end{array}$ & $\begin{array}{l}\text { upoer } \\
\text { Boaring } \\
\text { (8) }\end{array}$ & $\begin{array}{l}\text { Lower eeartina } \\
\text { (9) }\end{array}$ & $\begin{array}{l}\text { Lowor } \\
\text { (10) }\end{array}$ & $\begin{array}{l}\text { upper } \\
\text { (11) }\end{array}$ & & & & \\
\hline 11 ras & 1330 & & & & & & 86 & 70.1 & 72.7 & & & 69.2 & & 65 & \\
\hline t16ags & 1410 & & 66 & 400 & 5.715 & 5.5 & 68 & 71.2 & 73.7 & & & 69.7 & 120 & 65 & \\
\hline $11 / 895$ & 1428 & 0 & 74 & 500 & 5.4 & 5.5 & 93. & 73.1 & 75.7 & .019 & 035 & 70.7 & 120 & & \\
\hline 11 res & 1446 & & 85 & 600 & 10.8 & 7.4 & 101 & 75.0 & 77.7 & .026 & .048 & 73.0 & 120 & 65 & \\
\hline $11 / 895$ & 1500 & 260 & 99 & 700 & 7.1 & 6.7 & 108 & 77.0 & 79.8 & .058 & .040 & 76.0 & 120 & 65 & \\
\hline 14 / 895 & 1515 & 295 & 117 & 800 & $\mathbf{1 0 . 8}$ & 7.2 & 115 & 79.6 & 82.5 & .026 & .047 & 78.1 & 120 & 66 & .022 \\
\hline $11 / 5$ & 1525 & 333 & 139 & 900 & 7.8 & 8.1 & 120 & 82.7 & 85.1 & .025 & .046 & 77.3 & 120 & 66 & .020 \\
\hline $11 / 8 / 95$ & 1545 & 368 & 168 & 1000 & 10.3 & 8.4 & 120 & 83.1 & 85.7 & 0,31 & .107 & 77.4 & 120 & 65 & .018 \\
\hline $11 / 245$ & 1624 & 405 & 197 & 1100 & 12.4 & 10.3 & 131.2 & 87.5 & 89.8 & .034 & .072 & 81.1 & 120 & 68 & .032 \\
\hline $11 / 6$ gs & 1727 & 441 & 225 & 1200 & 13.9 & 11.4 & 144 & 93.8 & 95.7 & & & 84,0 & 120 & 69 & \\
\hline 118895 & 1800 & 441 & 226 & 1200 & 13.7 & 13.5 & 145.2 & 95.5 & 96.8 & & & 84.4 & 120 & 69 & \\
\hline 118095 & 1830 & 441 & 226 & 1200 & 13.5 & 12.8 & 146.5 & 96.3 & 97.3 & & & 84.9 & 120 & 72 & \\
\hline $11 / 295$ & 1900 & 441 & 226 & 1200 & 14.5 & 13.0 & 147.2 & 96.7 & 97.5 & & & 85.1 & 120 & 73 & \\
\hline 14895 & 1930 & 441 & 220 & $\{200$ & 14.5 & 13.2 & 146.9 & 97.1 & 97.4 & .055 & .095 & 85.4 & $\{20$ & 75 & .050 \\
\hline 11 Ros & 2000 & 441 & 226 & 1200 & 13.7 & 12.6 & 148.1 & 97.3 & 97.6 & & & 85.6 & 120 & 76 & \\
\hline $11 / 8 / 95$ & 2037 & 441 & 226 & 1200 & $14 . t$ & 13.2 & 147.0 & 97.3 & 97.7 & .048 & .112 & 86.0 & 120 & $\eta$ & \\
\hline 1119:9s & 2100 & 441 & 226 & 1200 & 14.2 & 13.1 & 147.0 & 97.2 & 97.6 & & & 85.5 & 120 & 78 & \\
\hline $11 / 835$ & 2130 & 441 & 226 & 1200 & 14.3 & 12.7 & 145.8 & $\$ 6.9$ & 97.6 & & & 85.3 & 120 & 80 & \\
\hline 11180s & 2219 & 441 & 225 & 1200 & 14,6 & $13.1^{\circ}$ & 144.4 & 96.5 & 96.6 & .045 & .092 & 85.0 & 120 & 81 & \\
\hline $11 / 8 \times 5$ & 2230 & 441 & 225 & 1200 & 13.6 & 14.6 & 145.6 & 96.6 & 97.1 & .045 & .092 & 84.9 & 120 & 82 & \\
\hline 11/RAS5 & 2300 & 441 & 225 & 1200 & 13.6 & 14.1 & 145.4 & 96.4 & 96.5 & & & 84.9 & 120 & 84 & \\
\hline 11/Res & 2330 & 441 & 224 & 1200 & 13.5 & $\{3.9$ & 145.1 & 98.5 & 96.5 & & & 84.9 & 120 & 84 & \\
\hline 119/95 & 2400 & 441 & 220 & 1200 & 14.1 & 13.9 & 145.1 & 95.9 & 96.8 & & & 84.6 & 120 & & \\
\hline 1119os & 0030 & 441 & 219 & 1200 & 15.4 & $\mathbf{1 3 . 4}$ & 145.1 & 96.0 & 96.6 & .032 & .086 & 84.4 & 120 & 88 & \\
\hline 11005 & 0100 & 441 & 219 & 1200 & 14,7 & 24.1 & 144.1 & 96.0 & 96.5 & .045 & .098 & 84.7 & 120 & 89 & .061 \\
\hline 119ugs & 0130 & 441 & 219 & 1200 & 14.6 & 14.2 & 144.2 & 95.7 & 96.2 & & & 84.5 & 120 & 90 & \\
\hline 11895 & 0200 & 441 & 219 & 1200 & 15.2 & 13.8 & 144.5 & 95.7 & 96.1 & .044 & .087 & 84.3 & 12. & 91 & \\
\hline 11/ONS5 & 0230 & 441 & 218 & 1200 & 14.3 & 12.6 & 144,4 & 95.6 & 95.9 & & & 84,3 & 120 & 92 & \\
\hline 14095 & 0300 & 441 & 218 & 1200 & 14.9 & เ3.4 & 144.1 & 95.4 & $\$ 5.8$ & & & 84.2 & 120 & 94 & \\
\hline $11 / 295$ & $0 \leq 30$ & 441 & 218 & 1200 & 14.6 & 13.6 & 143.7 & 95.3 & 95.8 & & & 84 & & & \\
\hline 119eres & 0409 & 441 & 219 & 1200 & 14.7 & 13.9 & 149.7 & 95.2 & 95.6 & .049 & .044 & 84 & 120 & 96 & \\
\hline 111805 & 0430 & 441 & 218 & 1200 & 14.7 & 13.7 & 142.6 & 95.0 & 95.4 & & & 83.7 & 120 & 98 & \\
\hline $11 / \$ / 95$ & 0500 & 441 & 218 & 1200 & 14.1 & 14.3 & 143.6 & 94.8 & 95.3 & & & 83.6 & 120 & 98 & \\
\hline $11+005$ & 0530 & 441 & 218 & 1200 & 14.5 & $\$ 3.9$ & 143.5 & 94.7 & 95.1 & & & 83.6 & 120 & 100 & \\
\hline 11 19/95 & 0600 & 441 & 218 & 1200 & 14.4 & 13.5 & 143,4 & 94.6 & 95.0 & .053 & .091 & 83.6 & 120 & 101 & \\
\hline 11985 & 0630 & 441 & 218 & 1200 & 14.2 & 13.7 & 143.3 & 94.5 & 94.9 & & & 83.6 & 120 & 102 & \\
\hline 111895 & 0700 & $441^{\circ}$ & 218 & 1200 & 14.2 & 13.9 & 143,1 & 94,4 & 94.4 & .066 & .106 & 83.6 & 120 & 504 & .07 \\
\hline 11PSOS & 0730 & 441 & 218 & 1200 & 14,4 & 14.3 & 143.1 & 94.4 & 94.9 & & & 83.5 & 120 & 105 & \\
\hline 1119495 & 0000 & 441 & 218 & 1200 & 14.9 & 14.5 & 143.2 & 94.4 & 94.8 & & & 83.6 & 40 & 106 & \\
\hline 11 Ros & 0830 & 441 & 224 & 1200 & 14,2 & 13.5 & 143.1 & 94.6 & 95.1 & & & 83.9 & 40 & $\$ 07$ & \\
\hline 11105 & 0900 & 441 & 223 & 1200 & 14,1 & 13.9 & 144.0 & 94.8 & 95.3 & & & 84 & 40 & 108 & \\
\hline 11/a/95 & 0930 & 441 & 223 & 1200 & 14.2 & 13.7 & 144.6 & 95.0 & 95.4 & & & 84.1 & 40 & 110 & \\
\hline
\end{tabular}


INITIAL 300 HP MIXER PUMP 90908-2 PERFORMANCE DEMONSTRATION TEST DATA SHEETS 400 AREA - MASF

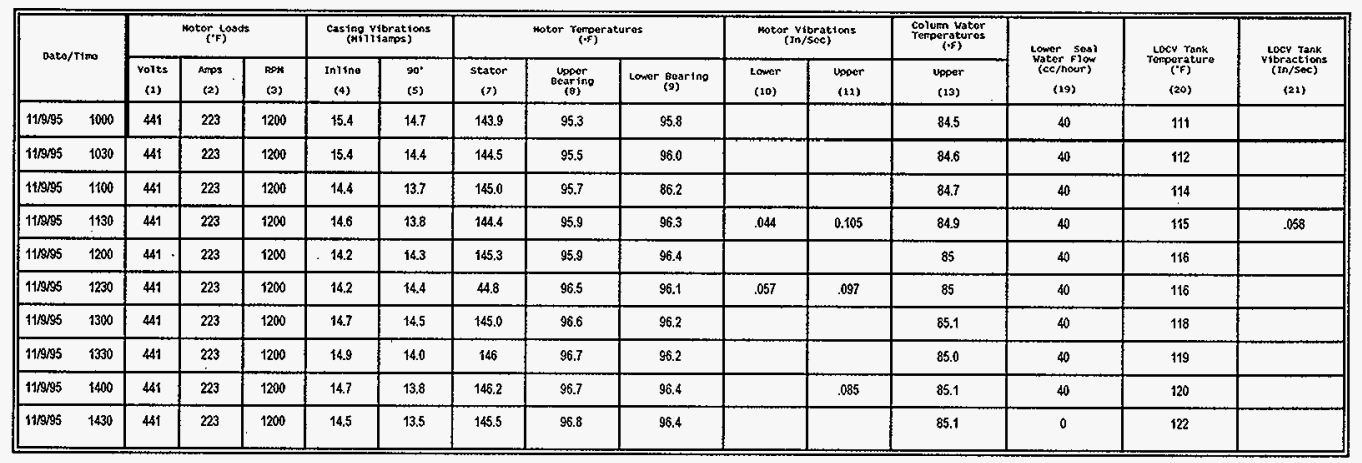




\begin{tabular}{|c|c|c|c|c|c|c|c|c|c|c|c|c|c|c|c|c|c|c|c|c|}
\hline \multirow[t]{2}{*}{ Dato Time } & \multicolumn{3}{|c|}{ Motor Loads } & \multicolumn{3}{|c|}{$\begin{array}{l}\text { Casing Vibrations } \\
\text { (Milliamps) }\end{array}$} & \multicolumn{3}{|c|}{$\begin{array}{l}\text { Motor Temperatures } \\
\qquad\left({ }^{*} \mathrm{~F}\right)\end{array}$} & \multicolumn{3}{|c|}{$\begin{array}{l}\text { Motor Vibrations } \\
\text { (In'Sec) }\end{array}$} & \multicolumn{2}{|c|}{$\begin{array}{c}\text { Column Water } \\
\text { Temperatures } \\
\left({ }^{\circ} \mathrm{F}\right)\end{array}$} & \multicolumn{4}{|c|}{$\begin{array}{l}\text { Water Pressures } \\
\text { (PSIG) }\end{array}$} & \multirow{2}{*}{$\begin{array}{c}\text { Lower Seal } \\
\text { Water Flow } \\
\text { (ccmour) } \\
\text { (19) }\end{array}$} & \multirow{2}{*}{$\begin{array}{c}\text { LOCV Tank } \\
\text { Temp } \\
\text { ('F) } \\
(20)\end{array}$} \\
\hline & $\begin{array}{c}\text { Volts } \\
\text { (1) }\end{array}$ & $\begin{array}{c}\text { Amps } \\
\text { (2) }\end{array}$ & $\begin{array}{l}\text { RPM } \\
\text { (3) }\end{array}$ & $\begin{array}{l}\text { Inline } \\
(4)\end{array}$ & $\begin{array}{l}90^{\circ} \\
(5)\end{array}$ & $\begin{array}{l}\text { Axial } \\
\text { (6) }\end{array}$ & $\begin{array}{c}\text { Sfator } \\
(7)\end{array}$ & $\begin{array}{c}\text { Upper } \\
\text { Bearing } \\
(8)\end{array}$ & \begin{tabular}{|c|} 
Lower \\
Bearing \\
$(9)$
\end{tabular} & $\begin{array}{l}\text { Lower } \\
\text { (10) }\end{array}$ & $\begin{array}{l}\text { Upper } \\
\text { (11) }\end{array}$ & $\begin{array}{l}\text { Thrust } \\
\text { (12) }\end{array}$ & $\begin{array}{l}\text { Upper } \\
\text { (13) }\end{array}$ & $\begin{array}{l}\text { Lower } \\
\text { (14) }\end{array}$ & $\begin{array}{l}\text { Upper Seal } \\
\text { Inlet [F] } \\
\text { (15) }\end{array}$ & $\begin{array}{c}\text { Column } \\
\text { vent [V] } \\
\text { (16) }\end{array}$ & $\begin{array}{l}\text { PCV } \\
\text { Outlet } \\
\text { (17) }\end{array}$ & $\begin{array}{l}\text { PCV } \\
\text { inlet } \\
\text { (18) }\end{array}$ & & \\
\hline $4 / 9 / 96 \quad 11: 00$ & 0 & 0 & 0 & 4.25 & 4.07 & 4.06 & 72.1 & 79.6 & 79.6 & & & & 78.7 & & 50 & 54 & 62 & 82 & $<34$ & 172 \\
\hline $4 / 9 / 96 \quad 11: 26$ & & & 750 & & & & & & & & & & & & & & & & $<34$ & 172 \\
\hline \multicolumn{21}{|l|}{$4 / 9 / 96 \quad 11: 30$} \\
\hline 4/9/96 12:00 & 295 & 113 & 800 & 13 & 12.5 & 5.5 & 88.4 & 84.5 & 85.7 & & & & 79.2 & & 48 & 54 & 61 & 82 & $<34$ & 172 \\
\hline $4 / 9 / 96 \quad 12: 30$ & 295 & 113 & 800 & 13.5 & 10.5 & 5.5 & 110.1 & 88.0 & 88.0 & & & & 80.5 & 104 & 48 & 54 & 61 & 82 & $<34$ & 172 \\
\hline $4 / 9 / 96 \quad 13: 00$ & 295 & $\{13$ & 800 & 13.5 & 14 & 5.3 & 120.5 & 92.2 & 92.3 & & & & 82.5 & 104 & 49 & 56 & 63 & 84 & $<34$ & 172 \\
\hline 4/9/96 13:30 & 295 & 113.5 & 800 & 13 & 13 & 5.1 & 125 & 97.2 & 97.2 & & & & 83.8 & 104 & 49 & 55 & 62 & 83 & $<34$ & 172 \\
\hline $4 / 9 / 96 \quad 14: 00$ & 295 & 113 & 800 & 12.5 & 12.5 & 5.5 & 128 & 94.7 & 92.5 & & & & 84,7 & 104.2 & 50 & 54 & 62 & 84 & $<34$ & 172 \\
\hline $4 / 9 / 96 \quad 14: 47$ & 295 & 113.3 & 800 & 12.5 & 12.5 & 5.5 & 128.5 & 93.9 & 93.9 & .022 & .041 & .018 & 85,4 & 104.6 & 50 & 55 & 61 & 83 & 34 & 172 \\
\hline $4 / 9 / 96 \quad 15: 48$ & 296 & 113.3 & 800 & 13 & 10 & 5.5 & 130.8 & 94.4 & 94.4 & .027 & .051 & .048 & 86.5 & 105.7 & 50 & 55 & 62 & 83 & $<34$ & 175 \\
\hline 4/9/96 $16: 34$ & 295 & 113 & 800 & 12.3 & 12.5 & 5.4 & 130.5 & 86.9 & 86.9 & .028 & .037 & .015 & 86.9 & 105.9 & 51 & 55.5 & 63 & 83 & $<34$ & 175 \\
\hline 4/9/96 17:07 & 296 & 113 & 800 & 10.4 & 8.4 & 5.6 & 130.2 & 101.5 & 100.5 & .027 & .058 & .009 & 87.1 & 106.9 & 52 & 56 & 63 & 83 & $<34$ & 175 \\
\hline 4/9/96 17:39 & 296 & 113.3 & 800 & 10.9 & 12.6 & 5.5 & 132.3 & 94.3 & 89.9 & .026 & .048 & .034 & 87.1 & 106.9 & 52 & 56.5 & 63 & 82 & $<34$ & 175 \\
\hline $4 / 9 / 96 \quad 18: 13$ & 296 & 113.3 & 800 & 12.5. & 12.2 & 5.5 & 129.2 & 93.4 & 93.5 & .035 & .026 & .041 & 87.2 & 107.1 & 52 & 57 & 63.5 & 83 & $<34$ & 175 \\
\hline $4 / 9 / 96 \quad 18: 51$ & 296 & 112.7 & 800 & 12.8 & 12.9 & 5.4 & +32.5 & 88.1 & 87.8 & .024 & .036 & .018 & 87.4 & 107.9 & 53 & 57 & 65 & 83 & $<34$ & 177 \\
\hline $4 / 9 / 96 \quad 19: 55$ & 296 & 113 & 800 & 12.2 & 11.9 & 5.3 & 129.3 & 77 & 77 & .026 & .057 & .044 & 88.6 & 108 & 54. & SB & 65 & 83 & $<34$ & 179 \\
\hline $4 / 9 / 9620 ; 50$ & 295 & 112.7 & 800 & 12.4 & 10.5 & 5.7 & 127 & 69.9 & 70.1 & .049 & .050 & .115 & 87.5 & 109 & 50.5 & 56 & 64 & 83 & $<34$ & 179 \\
\hline $4 / 9 / 96 \quad 22: 00$ & 296 & 112.7 & 800 & 9.8 & 10.2 & 5.4 & 127.2 & 63.2 & 63.2 & .039 & .086 & .049 & 85.4 & 109.4 & 52 & 56.5 & 64 & 84 & $<34$ & 180 \\
\hline 4/9/96 23:00 & 297 & 113.0 & 800 & 9.8 & 10.5 & 5.1 & 126.4 & 63.7 & 63.7 & .019 & .075 & .059 & 85.6 & 109.9 & 52 & 57 & 65 & 84 & $<34$ & 180 \\
\hline $4 / 10 / 960: 00$ & 296 & 112.5 & 800 & 9.8 & 10.4 & 5.5 & 125.2 & 58.1 & 57.9 & .037 & .046 & .133 & 85.4 & 110.4 & 53 & 57.5 & 85 & 82 & $<34$ & 180 \\
\hline 4/10/96 1:00 & 295 & 112.7 & 800 & 11.5 & 11.7 & 5.1 & 125.5 & 50.4 & * & .031 & .062 & .255 & 84.3 & 1 to. 1 & 54 & 58 & 65 & 82 & $<34$ & 180 \\
\hline $4 / 10 / 96 \quad 2: 00$ & 295 & 112.5 & 800 & 12.2 & 11.6 & 5.3 & 126.7 & * & $*$ & .018 & .096 & .081 & 84.3 & 111.0 & 51 & 55 & 63 & 82 & $<34$ & 180 \\
\hline $4 / 10 / 96 \quad 3: 17$ & 314 & 122.6 & 850 & 13.1 & 13.3 & 6.1 & 124.0 & $*$ & * & .022 & .055 & .198 & 83.6 & 111.6 & $51^{\circ}$ & .56 & 63 & 82 & $<34$ & 180 \\
\hline 4/10/96 4:00 & 314 & 122.6 & 850 & 14.2 & 14.4 & 5.7 & 126.7 & $*$ & + & .019 & .052 & .051 & 83.5 & 111.9 & 52 & 56 & 63 & 82 & $<34$ & 181 \\
\hline $4 / 10 / 965: 00$ & 314 & 122.6 & 850 & $\$ 4.1$ & 14.6 & 5.5 & 124.5 & * & * & .020 & .089 & .217 & 83 & 112.1 & 52 & 57 & 64 & 82 & $<34$ & 181 \\
\hline $4 / 10 / 966: 00$ & 305 & 117.9 & 825 & 11.5 & 13,8 & 4,8 & 125.2 & * & * & .024 & $.028^{\prime}$ & .036 & 84,3 & 113.1 & 53 & 58 & 65 & 82 & $<34$ & 182 \\
\hline $4 / 10 / 967: 00$ & 305 & 117.9 & 825 & 12.4 & 12.5 & 5.9 & 124.5 & $*$ & * & .016 & .031 & .039 & 83.1 & 113.0 & 54 & 58 & 65 & 82 & $<34$ & 185 \\
\hline $4 / 10 / 968 ; 00$ & 305 & 117.9 & 825. & 13.4 & 12.1 & 5.8 & 125 & • & * & .023 & .037 & .057 & 82.5 & 113.5 & 55 & 59 & 67 & 82 & $<34$ & 189 \\
\hline $4 / 10 / 96 \quad 9: 01$ & 305 & 117.8 & 825 & 12.4 & 12.3 & 5.6 & 123.2 & * & * & .022 & .035 & .042 & 82.7 & 114.5 & 56 & 60 & 68 & 81 & $<34$ & 189 \\
\hline 4/10/96 9:35 & 350 & 147.3 & 950 & 12.3 & 14.0 & 5.4 & 126.4 & * & * & .041 & .030 & .034 & 82.4 & 114.2 & so & 55 & 63 & 81 & $<34$ & 190 \\
\hline 4/40/96 10:00 & 350 & 147.3 & 950 & 12.7 & 17.8 & 5.5 & 126.1 & * & $*$ & .062 & .033 & .031 & 82.4 & 115.2 & 50 & 55 & 63 & 81 & 34 & 190 \\
\hline $4 / 10 / 96 \quad 10: 34$ & 350 & 147.3 & 950 & 14.2 & 13.5 & 5.9 & 128 & * & $*$ & .073 & .087 & .024 & 82.6 & 115.6 & 52 & 56 & 63 & 81 & $<34$ & 180 \\
\hline 4/10/96 11:0S. & $350^{\circ}$ & 147.3 & 950 & 13.2 & 11.7 & 5.6 & 126.6 & • & • & .039 & .032 & .033 & 84.4 & 116.5 & 52 & 57 & 64 & 81 & $<34$ & 191 \\
\hline 4/10/96 11:31 & 350 & 146.1 & 950 & 12.8 & 13.6 & 5.4 & 128.2 & • & * & .032 & .062 & .046 & 84.4 & 115.9 & 52 & 57 & 65 & 81 & $<34$ & 192 \\
\hline $4 / 10 / 96 \quad 12: 04$ & 350 & 146.7 & 950 & 13.0 & 13.0 & 5.8 & 127.9 & * & * & .031 & .050 & .029 & 84.4 & 117.4 & 52 & 58 & 65 & 81 & $<34$ & 192 \\
\hline $4 / 10 / 96 \quad 12: 30$ & 350 & 146.7 & 950 & 13.0 & 13.0 & 5.7 & 127.4 & + & * & .031 & .048 & .030 & 85 & 118. & 54 & 59 & 67 & 81 & $<34$ & 192 \\
\hline 4/10/96 13:00 & 350 & 146.9 & 950 & 12.8 & 12.2 & 5.7 & 128.3 & $*$ & * & .028 & .094 & .096 & 84.9 & 118.5 & 55 & 59 & 67 & 81 & $<34$ & 192 \\
\hline $4 / 10 / 96 \quad 13: 30$ & 350 & 147 & 950 & 13.0 & 15.2 & 5.4 & 128.4 & • & * & 0.046 & 0.057 & 0.034 & 85.0 & 118.6 & 56 & 60 & 68 & 80 & $<34$ & 196 \\
\hline 4/10/96 14:05 & 350 & 146.4 & 949.2 & 13.4 & 13.9 & 5.8 & 128.4 & - & * & 0.057 & 0.063 & 0.028 & 85.3 & 119.4 & 50 & 54 & 62.5 & 81 & $35 ?$ & 198.5 \\
\hline
\end{tabular}


400 AREA - MASF

\begin{tabular}{|c|c|c|c|c|c|c|c|c|c|c|c|c|c|c|c|c|c|c|c|c|}
\hline \multirow[t]{2}{*}{ Date Time } & \multicolumn{3}{|c|}{ Motor Loads } & \multicolumn{3}{|c|}{$\begin{array}{l}\text { Casing Vibrations } \\
\text { (Milliamps) }\end{array}$} & \multicolumn{3}{|c|}{$\begin{array}{l}\text { Motor Temperatures } \\
\qquad\left({ }^{\circ} \mathrm{F}\right)\end{array}$} & \multicolumn{3}{|c|}{$\begin{array}{l}\text { Motor Vibrations } \\
\quad \text { (In'sec) }\end{array}$} & \multicolumn{2}{|c|}{$\begin{array}{l}\text { Column Water } \\
\text { Temperatures } \\
\left.\text { ( }{ }^{\circ} \mathrm{F}\right)\end{array}$} & \multicolumn{4}{|c|}{$\begin{array}{c}\text { Water Pressures } \\
\text { (PSIG) }\end{array}$} & \multirow{2}{*}{$\begin{array}{c}\text { Lower Seat } \\
\text { Water Flow } \\
\text { (cofhour) } \\
\text { (19) }\end{array}$} & \multirow{2}{*}{$\begin{array}{c}\text { LDCV Tank } \\
\text { Temp } \\
\left(^{\circ} \mathrm{F}\right) \\
(20)\end{array}$} \\
\hline & $\begin{array}{c}\text { Volts } \\
\text { (1) }\end{array}$ & $\begin{array}{c}\text { Amps } \\
\text { (2) }\end{array}$ & $\begin{array}{l}\text { RPM } \\
\text { (3) }\end{array}$ & $\begin{array}{l}\text { Inline } \\
\text { (4) }\end{array}$ & $\begin{array}{l}90^{\circ} \\
(5)\end{array}$ & $\begin{array}{l}\text { Axial } \\
\text { (6) }\end{array}$ & $\begin{array}{c}\text { Stator } \\
\text { (7) }\end{array}$ & $\begin{array}{c}\text { Upper } \\
\text { Bearing } \\
(8)\end{array}$ & $\begin{array}{c}\text { Lower } \\
\text { Bearing } \\
(9)\end{array}$ & $\begin{array}{c}\text { Lower } \\
(10)\end{array}$ & $\begin{array}{l}\text { Upper } \\
\text { (11) }\end{array}$ & $\begin{array}{l}\text { Thrust } \\
\text { (12) }\end{array}$ & $\begin{array}{l}\text { Uppor } \\
\text { (13) }\end{array}$ & $\begin{array}{l}\text { Lower } \\
\text { (14) }\end{array}$ & $\begin{array}{c}\text { Upper Seal } \\
\text { Inlet [F] } \\
\text { (15) }\end{array}$ & $\begin{array}{c}\text { Column } \\
\text { Vent [M] } \\
\text { (16) }\end{array}$ & $\begin{array}{l}\text { PCV } \\
\text { Outlet } \\
\text { (17) }\end{array}$ & $\begin{array}{l}\text { PCV } \\
\text { Inlet } \\
(18)\end{array}$ & & \\
\hline $4 / 10 / 96 \quad 14: 37$ & 350 & 146.9 & 949.2 & 13.6 & 12.7 & 6.2 & 129.4 & * & " & 0.033 & 0.063 & 0.048 & 85.6 & 120.4 & 51 & 56 & 63 & 81 & 35 & 200 \\
\hline $4 /$ to/96 $15: 03$ & 350 & 146.4 & 949.2 & 13.4 & 13.7 & 5.5 & 127.3 & 87.57 & 90.38 & $0.040^{\circ}$ & 0.015 & 0.033 & 86.2 & 121.5 & s2 & 56.5 & 64 & 80 & 35 & 200 \\
\hline 4/10/96 $15: 20$ & 387 & 175 & 1050 & & & & & & & & & & & & & & & & & 200 \\
\hline $4 / 10 / 96 \quad 15: 31$ & 387 & 174.4 & 1050 & 13.7 & 15.9 & 6.4 & 130.3 & 88.03 & 91.02 & 0.037 & 0.124 & 0.028 & 86.1 & 121.5 & 52 & 56.5 & 63 & 80.5 & 35 & 200 \\
\hline 4/10/96 16:00 & 387 & 175.3 & 1050 & 16.5 & 16.9 & 6.4 & 135.4 & 88.82 & 96.43 & 0.047 & 0.162 & 0.036 & 86.1 & 122.5 & 54 & 57.5 & 65 & 81 & 35 & 200 \\
\hline $4 / 10 / 96 \quad 16: 30$ & 387 & 175.3 & 1050 & 16.4 & 20.0 & 6.6 & 136.0 & 93.99 & $\$ 6.94$ & 0.072 & 0.160 & 0.021 & 86.5 & 123.5 & 54 & 57.5 & 65 & 80 & 35 & 201 \\
\hline $4 / 10 / 96 \quad 16: 36$ & 295 & 112.5 & 799.2 & & & & & & & & & & & & & & & & & 201 \\
\hline 4/10/96 17:07 & 295 & 112.5 & 799.2 & 13.0 & 12.0 & 5.9 & 129.2 & 93.25 & 96.43 & 0.021 & 0.038 & 0.027 & 86.5 & 124.5 & 55 & 59 & 86 & 83 & $<34$ & 201 \\
\hline 4/10/96 17:27 & 295 & 112.5 & 799.2 & 12.4 & 11.3 & 5.3 & 126.7 & 92.18 & 95.65 & .081 & .059 & .020 & 86.1 & 128.5 & 56 & 60 & 68 & 82 & $<34$ & 201 \\
\hline $4 / 10 / 96 \quad 17: 59$ & 295 & 112.5 & 799.2 & 11.4 & 10.4 & 5.2 & 126.3 & 91.82 & 95.05 & .031 & .051 & .019 & 85.3 & 124.7 & 56 & 60 & 68 & 82 & $<34$ & 201 \\
\hline 4/10/96 19:02, & 295 & 112.7 & 799.2 & 12.7 & 10.9 & 5.3 & 124.5 & 90.8 & 94.03 & .048 & .042 & .021 & 85.1 & 126.1 & 51 & 55 & 63 & 82 & $<34$ & 201 \\
\hline $4 / 10 / 9620: 00$ & 296 & 112.5 & 799.2 & 12.2 & 10.1 & 5.3 & 123.9 & 90.38 & 93.62 & .021 & .080 & .114 & 84.8 & 123.9 & 51 & 56 & 63 & 82 & $<34$ & 201 \\
\hline 4/10/96 21:00 & 295 & 112.5 & 799.2 & 10.2 & 12.4 & 5.3 & 126.1 & 90.37 & 93.26 & .024 & .046 & .030 & 84.6 & 124.9 & 49 & 53 & 62 & 82 & $<34$ & 200 \\
\hline $4 / 10 / 9622: 00$ & 296 & 112.2 & 799.2 & 11.4 & 12.5 & 5.3 & 124.4 & 89.85 & 93.18 & .029 & .035 & .037 & 84.4 & 121.5 & 48 & 51.5 & 60 & 82 & $<34$ & 200 \\
\hline $4 / 10 / 96 \quad 23: 00$ & $296^{\prime}$ & 112.7 & 799.2 & 10.5 & 12.2 & 5.3 & 121.5 & 89.6 & 92.69 & .018 & .040 & .032 & 83.7 & 117.9 & 49 & 53 & 60 & 83 & $<34$ & 200 \\
\hline $4 / 10 / 96 \quad 23: 45$ & 296 & 112.7 & 799.2 & & & & & & & & & & & & 42 & 47 & 55 & 83 & $>335$ & 200 \\
\hline 4/10/96 $23: 55$ & 0 & 0 & 0 & \multicolumn{11}{|c|}{ SHUTOOWN PUMP \& SECURED SEAL WATER FLOW } & 45 & 49 & 57 & 83 & $>335$ & 200 \\
\hline 4/11/96 06:45 & 0 & 0 & 0 & \multicolumn{11}{|c|}{ INITIATED SEAL WATER FLOW AFTER READINGS WERE TAKEN } & 38 & & 50 & 84 & $>335$ & 195 \\
\hline 4/11/96 $07: 16$ & 0 & 0 & 0 & & & & & & & & & & & & 54 & 58 & 65 & 84 & $>335$ & 195 \\
\hline 4/11/56 08:12 & 0 & 0 & 0 & & & & & & & & & & & & 54 & 59 & 67 & 96 & $>335$ & 195 \\
\hline $4 / 11 / 96 \quad 10: 20$ & 0 & 0 & 0 & & & & 72.8 & 77 & 77 & 0 & 0 & 0 & 71.9 & 98.4 & 55 & 59 & 67 & 70 & 750 & 195 \\
\hline 4/11/96 11:08 & 0 & 0 & 0 & & & & 72.5 & 77 & 77 & 0 & 0 & 0 & 72.0 & 98.1 & 55 & 59 & 67 & 94 & 650 & 195 \\
\hline $4 / 11 / 96 \quad 11: 06$ & 296 & 113.5 & 800 & 12.3 & 13.3 & 5.5 & 80.9 & 77.2 & 77.2 & .036 & .053 & .036 & 72.0 & 97.3 & 55 & 59 & 67 & 94 & $160-650$ & 195 \\
\hline 4/11/96 11:12 & 296 & 113.5 & 800 & & & & 89.2 & 77.5 & 77.5 & & & & 72.0 & 97.9 & 55 & 59 & 67 & 70 & 300 & 195 \\
\hline 4/11/96 11:15 & 0 & 0 & 0 & \multicolumn{11}{|c|}{ SHUTDOWN PUMP } & & & & & 760 & \\
\hline $4 / 12 / 96 \quad 12: 52$ & & & 800 & & & & & & & & & & & & & & & & 80 & \\
\hline $4 / 12 / 96$ 12:55 & 0 & 0 & 0 & & & & 67.6 & 108.11 & 108.37 & 0 & 0 & 0 & 67.5 & 86.9 & 55 & 59 & & & 380 & \\
\hline 4/12/96 $12: 59$ & & & 800 & & & & & & & & & & & & & & & & 80 & \\
\hline 4/12/96 13:01 & & & & & & & & & & & & & & & & & & & 140 & \\
\hline 4/12/96 13:02 & & & & & & & & & & & & & & & & & & & 380 & \\
\hline $4 / 12 / 96 \quad 13: 25$ & 296 & $\$ 14.7$ & 800 & 12.3 & 11.7 & 5.1 & 98.4 & 108.99 & 108.15 & .021 & .031 & .029 & 68.8 & 87.7 & 56 & 60 & 67 & 95 & 190 & 175 \\
\hline $4 / 12 / 96 \quad 13: 55$ & 296 & 114.5 & 800 & 10.2 & 12.6 & 6.4 & 105.3 & 109.65 & 109.78 & .027 & .052 & .078 & 70.4 & 88 & 56 & 60 & 67 & 95 & $<120$ & 175 \\
\hline $4 / 12 / 96 \quad 14: 25$ & 296 & 114.2 & 800 & 10.8 & 10.3 & 6.1 & 113.0 & 110.42 & 110.58 & .050 & .054 & .045 & 72.4 & 88.1 & 56 & 60 & 67 & 95 & 25 & 175 \\
\hline 4/12/96 14:55 & 295 & 114.5 & 800 & 12.8 & 10.8 & 5.7 & 117.0 & 110.82 & 111.0 & .034 & .062 & .038 & 73.6 & 88.9 & 56 & 60 & 67 & 95 & 0 & 175 \\
\hline 4/12/96 $15: 44$ & 295 & 114.5 & 800 & & & & & & & & & & & & & & & & & \\
\hline $4 / 12 / 96 \quad 15: 52$ & 375 & 161.7 & 1018.6 & 14.4 & 20 & 5.5 & 112.6 & 111.22 & 110.94 & .055 & .076 & .020 & 72.5 & 88 & 56 & 60 & 67 & 95 & 0 & 175 \\
\hline $4 / 15 / 9608: 03$ & 0 & 0 & 0 & & & & & & & & & & & & 38 & 42 & 50 & & 0 & 145 \\
\hline 4/15/96 $09: 20$ & & & & & & & & & & & & & & . & & & & & & \\
\hline $4 / 15 / 96 \quad 15: 30$ & 350 & 149 & 950 & & & & & ; & & & & & & & & & & & & 142 \\
\hline $4 / 15 / 96 \quad 15: 52$ & & & & & & & & & & & SECL & RED PUM & & & & & & & & \\
\hline $\mid 4 / 16 / 96 \quad 10: 37$ & 295 & 113.8 & 799.2 & 11.4 & 10.2 & 5.2 & 98.2 & 109.31 & 109.14 & 0.041 & 0.058 & 0.048 & 68.6 & 68.7 & 55 & 59.0 & 67 & 95 & 38 & 138 \\
\hline
\end{tabular}


300 HP MIXER PUMP 90908-2 PERFORMANCE DEMONSTRATION TEST DATA SHEETS 400 AREA - MASF

\begin{tabular}{|c|c|c|c|c|c|c|c|c|c|c|c|c|c|c|c|c|c|c|c|c|}
\hline \multirow[t]{2}{*}{ Date Time } & \multicolumn{3}{|c|}{ Motor Loads } & \multicolumn{3}{|c|}{$\begin{array}{l}\text { Casing Vibrations } \\
\text { (Miltiamps) }\end{array}$} & \multicolumn{3}{|c|}{$\begin{array}{l}\text { Motor Temperałures } \\
\left({ }^{\circ} \mathrm{F}\right)\end{array}$} & \multicolumn{3}{|c|}{$\begin{array}{c}\text { Motor Vibrations } \\
\text { (In/Sec) }\end{array}$} & \multicolumn{2}{|c|}{$\begin{array}{c}\text { Column Water } \\
\text { Temperatures } \\
\left({ }^{\circ} \mathrm{F}\right)\end{array}$} & \multicolumn{4}{|c|}{$\begin{array}{l}\text { Water Pressures } \\
\text { (PSIG) }\end{array}$} & \multirow{2}{*}{$\begin{array}{l}\text { Lower Seal } \\
\text { Water Flow } \\
\text { (comour) } \\
\text { (19) }\end{array}$} & \multirow{2}{*}{$\begin{array}{c}\text { LDCV Tank } \\
\text { Tomp } \\
\text { ("F) } \\
\text { (20) }\end{array}$} \\
\hline & $\begin{array}{l}\text { Volts } \\
\text { (1) }\end{array}$ & $\begin{array}{c}\text { Amps } \\
\text { (2) }\end{array}$ & $\begin{array}{c}\text { RPM } \\
(3)\end{array}$ & $\begin{array}{l}\text { Inline } \\
\text { (4) }\end{array}$ & $\begin{array}{l}90^{\circ} \\
\text { (5) }\end{array}$ & $\begin{array}{l}\text { Axial } \\
\text { (6) }\end{array}$ & $\begin{array}{c}\text { Stator } \\
(7)\end{array}$ & $\begin{array}{c}\text { Upper } \\
\text { Bearing } \\
\text { (8) }\end{array}$ & $\begin{array}{c}\text { Lower } \\
\text { Bearing } \\
(9)\end{array}$ & $\begin{array}{l}\text { Lower } \\
(10)\end{array}$ & $\begin{array}{l}\text { Upper } \\
(11)\end{array}$ & $\begin{array}{l}\text { Thrust } \\
\text { (12) }\end{array}$ & $\begin{array}{l}\text { Upper } \\
\text { (13) }\end{array}$ & $\begin{array}{l}\text { Lower } \\
\text { (14) }\end{array}$ & $\begin{array}{l}\text { Upper Seal } \\
\text { Inlet [F] } \\
(15)\end{array}$ & $\begin{array}{c}\text { Column } \\
\text { Vent } M \\
(16)\end{array}$ & $\begin{array}{l}\text { PCV } \\
\text { Outlet } \\
(17)\end{array}$ & $\begin{array}{l}\text { PCV } \\
\text { In!et } \\
(18)\end{array}$ & & \\
\hline $4 / 16 / 96 \quad 11,08$ & 290 & 114.2 & 798.0 & 10.6 & 11.3 & 5.9 & 106.2 & 110.08 & 109.89 & 0.043 & 0.062 & 0.041 & 70.4 & 69.1 & 55 & 59.5 & 67 & 94 & $<34$ & 142 \\
\hline $4 / t 6 / 96 \quad 11: 38$ & 296 & 113.8 & 798.2 & 11.13 & 12.1 & 5.2 & 113.9 & 110.73 & 110.54 & 0.045 & 0.059 & 0.045 & 72.0 & 69.2 & 55 & 60.0 & 67 & 94 & $<34$ & 142 \\
\hline $4 / 16 / 96 \quad 12: 15$ & 296 & 113.5 & 798.9 & 11.95 & 11.5 & 6.4 & 116.4 & 111.23 & 111.01 & 0.044 & 0.068 & 0.042 & 73.3 & 69.7 & 56 & 60.0 & 67 & 94 & $<34$ & 142 \\
\hline $4 / 16 / 96 \quad 12: 45$ & 295 & 113.8 & 798.8 & 12.63 & 11.1 & 61 & 117.6 & 111.60 & 111.34 & 0.034 & 0.043 & 0.052 & 74.9 & 70.0 & 56 & 60.1 & 69 & 95 & $<34$ & 142 \\
\hline $4 / 16 / 96+3: 15$ & 295 & 114.2 & 798.9 & 13.34 & 12.5 & 4.95 & 120.7 & 111.92 & 111.60 & 0.042 & 0.065 & 0.046 & 76.0 & 70.3 & 56 & 61.0 & 68 & 94 & $<34$ & 142 \\
\hline $4 / 16 / 96 \quad 13: 48$ & 296 & 114.4 & 799.2 & 12.69 & 12.9 & 5.71 & 121.9 & 112.11 & 111.70 & .041 & .060 &, 046 & 76.6 & 70.4 & 56 & 61.5 & 68 & 95 & $<34$ & 141 \\
\hline $4 / 16 / 96 \quad 14: 15$ & 297 & 113.5 & 799.2 & 11.45 & 13.1 & 5.06 & 119.7 & 112.24 & 111.78 & .031 & .069 & .063 & 77.1 & 70.5 & 57 & 62 & 68 & 94 & $<34$ & 142 \\
\hline $4 / 16 / 96 \quad 14: 44$ & 297 & 113.3 & 798.9 & 10.33 & 14.6 & 5.65 & 121.9 & 112,36 & 111.86 & .044 & .068 & .048 & 77.6 & 70.7 & 57 & 62.5 & 68 & 95 & $<34$ & 142 \\
\hline $4 / 16 / 96 \quad 15: 13$ & 295 & 113.8 & 798.9 & 10.7 & 14.6 & 5.5 & 121.8 & 112.46 & 111.92 & 0.023 & 0.062 & 0.041 & 78.0 & 70.6 & 58 & 63.0 & 68 & 74 & $<34$ & 145 \\
\hline $4 / 16 / 86 \quad 15: 59$ & 295 & 113.8 & 799.2 & 10.9 & 14.6 & 5.0 & 121.8 & 112.58 & 112.02 & 0.026 & 0.049 & 0.029 & 78.6 & 70.9 & 58 & 64.5 & 68 & 74 & $<34$ & 147 \\
\hline $4 / 16 / 96 \quad 16: 30$ & 297 & 113.8 & 799.2 & 11.5 & 14.3 & 5.2 & 123.3 & 112.67 & 112.12 & .020 & .075 & .026 & 79.1 & 70.9 & 59 & 64 & 68 & 73 & $<34$ & 147 \\
\hline $4 / 16 / 96 \quad 17: 02$ & 295 & 113.5 & 798.9 & 11.7 & 13.5 & 5.0 & 123.8 & 112.72 & $\$ 12.15$ & .024 & .067 & .038 & 79.4 & 71.0 & 60 & 64 & 68 & 73 & $<34$ & 148 \\
\hline $4 / 16 / 96 \quad 17: 31$ & 297 & 113.0 & 798.9 & 11.5 & 12.0 & 5.2 & 123.3 & 112.74 & 112.17 & .019 & .058 & .023 & 79.5 & 71.2 & 60 & 64 & $\Leftrightarrow 8$ & 74 & $<34$ & 148 \\
\hline 4/16/96 $17: 59$ & 295 & 114.2 & 798.9 & 11.4 & 12.3 & 5.3 . & 124.0 & 112.76 & 112.19 & .028 & .039 & .030 & 79.6 & 71.1 & 60 & 64.5 & 68 & 74.5 & $<34$ & 148 \\
\hline $4 / 16 / 95 \quad 18: 31$ & 296 & 113.8 & 798.9 & 11.8 & 12.2 & 5.7 & 123.2 & 112.77 & 112.20 & .032 & .059 & .037 & 79.7 & 71.2 & 53 & 57 & 64 & 73.5 & $>280$ & 149 \\
\hline $4 / 16 / 96 \quad 19: 00$ & 296 & 113.0 & 799.2 & 12.5 & 12.1 & 5.3 & 124.8 & 112.77 & 112.18 & .026 & .074 & .044 & 79.6 & 71.1 & 54 & 59 & 64 & 74 & $>280$ & 149 \\
\hline 4/16/96 19:30 & 295 & 113.5 & 798.9 & 12.6 & 12.0 & 5.2 & 124.2 & 112.74 & 112.13 & .033 & .033 & .042 & 79.4 & 71.4 & 55 & 59 & 64 & 82 & 43 & 150 \\
\hline $4 / 16 / 9620: 20$ & 297 & 113.8 & 798.9 & 12.5 & 12 & 5 & 125.4 & 112.74 & 112.13 & .031 & .069 & .067 & 79.4 & 72.2 & 55 & 59 & 64 & 82 & $>280$ & 150 \\
\hline 4/16/96 20:49 & 296 & 113.8 & 798.9 & 12.5 & 12.2 & 5.1 & 123.6 & 112.73 & 112.12 & .026 & .05 & .04 & 70.3 & 72.1 & 55 & 59 & 64 & 82 & 48 & 150 \\
\hline $4 / 16 / 96 \quad 21: 17$ & 290 & 113.5 & 798.8 & 12.3 & 13.1 & 5.0 & 122.5 & 112.72 & 112.09 & .03 & .048 & .042 & 79.3 & 72.8 & 56 & 59 & 64 & 82 & $<34$ & 150 \\
\hline $4 / 16 / 96 \quad 21: 45$ & 296 & 113.8 & 798.8 & 12,3 & 13.1 & 5.0 & 123.1 & 112.73 & 112.09 & .031 & .042 & .044 & 79.4 & 72.7 & 55 & 59 & 64 & 82 & $<34$ & 150 \\
\hline $4 / 16 / 96 \quad 22: 14$ & 296 & 113.8 & 798.8 & 12.3 & 13.1 & 5.0 & 123.5 & 112.73 & 112.05 & .028 & .044 & .041 & 79.3 & 72.3 & 55 & 59 & 64 & 82 & $<34$ & 150 \\
\hline $4 / 16 / 96 \quad 22: 45$ & 296 & 113.9 & 799.0 & 11.8 & 12.2 & 5.8 & 122.9 & 112.46 & 111.98 & .029 & .028 & .032 & 79.1 & 72.3 & 55 & 60 & 64 & 82 & $<34$ & 150 \\
\hline $4 / 16 / 96 \quad 23: 47$ & 296 & 113.8 & 799 & 11.8 & 11.5 & 5.2 & 122.3 & 112.61 & 111.91 & .038 & .064 & .044 & 79 & 72.1 & 56 & 61 & 62 & 78 & $<34$ & 150 \\
\hline $4 / 16 / 9623: 45$ & 296 & 113.8 & $7 \subseteq 9.1$ & 11.8 & 11.5 & 5.2 & 122.9 & 112.6 & 111.9 & .033 & .044 & .039 & 79.2 & 72 & 56 & $6 t$ & 62 & 77.5 & $<34$ & 150 \\
\hline 4/17/96 $0: 15$ & 297 & 113.9 & 799.1 & 11.8 & 11.5 & 5.2 & $12 t .8$ & 112.62 & 111.91 & .05 & .067 & .045 & 78.1 & 71.8 & 56 & 61 & 62 & 78 & $<34$ & 150 \\
\hline $4 / 17 / 96 \quad 0: 45$ & 295 & 113.8 & 798.9 & 11.8 & 11.5 & 5.2 & 122.1 & 112.64 & 111.92 & .032 & 05 & .033 & 78.1 & 71.2 & 56 & 61 & 62 & 78 & $<34$ & 150 \\
\hline $4 / 17 / 96 \quad 1: 15$ & 295 & 113.5 & 798.9 & 11.8 & 11.5 & 5.2 & 122.1 & 112.78 & +11.97 & .037 & .034 & .028 & 78.2 & 71,0 & 56 & 61 & 62 & 78 & $<34$ & 150 \\
\hline 4/17/96 $1: 45$ & 295 & 113.9 & 798.9 & 11.8 & 11.5 & 5.2 & 123.2 & 112.81 & 111.96 & .033 & .028 & .034 & 78.5 & 71.2 & 56 & 61 & 62 & 78 & $<34$ & 150 \\
\hline $4 / 17 / 96 \quad 2: 15$ & 295 & 113.9 & 798.9 & 11.8 & 11.5 & 5.2 & 123.0 & 112.79 & 111.94 & .03 & .026 & .030 & 79.0 & 71.5 & 56 & 61 & 62 & 78 & $<34$ & 150 \\
\hline $4 / 17 / 96 \quad 2: 48$ & 295 & 113.3 & 798.8 & 12.2 & 11.5 & 5.5 & 121.7 & 112.80 & 112.1 & .052 & .038 & .023 & 78.7 & 72.1 & 56 & 61 & 63 & 78 & $<34$ & 150 \\
\hline $4 / 17 / 96 \quad 3: 15$ & 295 & 113.3 & 798,8 & 12.2 & 11.5 & 5.5 & 122.5 & 112.80 & 112.1 & .044 & .034 & .031 & 78.1 & 72.1 & 56 & 61 & 63 & 78 & $<34$ & 150 \\
\hline $4 / 17 / 96 \quad 3: 45$ & 296 & 113.8 & 799.1 & 12.2 & 11.5 & 5.5 & 121.8 & 112.84 & 112.1 & .027 & .028 & .044 & 78.4 & 72.2 & 58 & 64 & 63 & 78 & $<34$ & 150 \\
\hline $4 / 17 / 90 \quad 4: 15$ & 296 & 113.8 & 798.9 & 12.2 & 11,5 & 5.5 & 122.4 & 112.79 & 111.96 & .048 & .03 & .027 & 78.8 & 71.9 & 58 & 64 & 63 & 78 & $<34$ & 150 \\
\hline $4 / 17 / 96 \quad 4: 45$ & 296 & 113.8 & 798.9 & 12.2 & 11.5 & 5.5 & 123.1 & 112.80 & 111,96 & .033 & .043 & .023 & 79.1 & 72.2 & 58 & 64 & 63 & 78 & $<34$ & 150 \\
\hline $4 / 17 / 965: 30$ & 296 & 113.5 & 799.1 & 12.2 & 11.5 & 5.5 & 122.6 & 112.78 & 111.89 & .055 & .038 & .044 & 79.1 & 72.1 & 58 & 64 & 63 & 78 & $<34$ & 150 \\
\hline $4 / 17 / 966: 00$ & 296 & 113.8 & 798.8 & 12.2 & 11.5 & 5.5 & 121.8 & 112.83 & 111.91 & .042 & .028 & .031 & 79.2 & 72.3 & 58 & 64 & 63 & 82 & $<34$ & 150 \\
\hline 4/17/96 6:30 & 296 & 113.8 & 798.8 & 12.2 & 11.5 & 5.5 & 122.2 & 112.85 & 111.92 & $.0 \$ 1$ & .037 & .021 & 78.8 & 71.6 & 58 & 64 & 63 & 82 & $<34$ & 150 \\
\hline $4 / 47 / 196 \quad 7: 00$ & 296 & 113.5 & 798.8 & 12.2 & 11.5 & 5.5 & 119.1 & 112.54 & 111.35 & .044 & .038 & .028 & 77.5 & 70.8 & 59 & 64 & 63 & 82 & $<34$ & 150 \\
\hline $4 / 17 / 96 \quad 7: 25$ & 296 & 113.8 & 798.7 & 12.5 & 11.5 & 5.5 & 118.6 & $112.5 t$ & 111.32 & .021 & .04 & .036 & 77.1 & 70.2 & 59 & 64 & 63 & 82 & $<34$ & 150 \\
\hline $4 / 17 / 968: 00$ & 296 & 113.6 & 798.8 & 12.5 & 11.6 & 5.6 & 118.1 & 112.08 & 111.37 & .044 & .046 & .036 & 76.9 & 70.6 & 54 & 60 & 62 & 83 & $<34$ & 150 \\
\hline
\end{tabular}



400 AREA - MASF

\begin{tabular}{|c|c|c|c|c|c|c|c|c|c|c|c|c|c|c|c|c|c|c|c|c|}
\hline \multirow[t]{2}{*}{ Date Time } & \multicolumn{3}{|c|}{ Motor Losds } & \multicolumn{3}{|c|}{$\begin{array}{l}\text { Casing Vibrations } \\
\text { (Mililiamps) }\end{array}$} & \multicolumn{3}{|c|}{$\begin{array}{c}\text { Motor Temperatures } \\
\left({ }^{\circ} \mathrm{F}\right)\end{array}$} & \multicolumn{3}{|c|}{$\begin{array}{l}\begin{array}{c}\text { Motor Vibrations } \\
\text { (In/Sec) }\end{array}\end{array}$} & \multicolumn{2}{|c|}{$\begin{array}{l}\text { Columin Water } \\
\text { Tomperatures } \\
\left({ }^{\circ} \mathrm{F}\right)\end{array}$} & \multicolumn{4}{|c|}{$\begin{array}{l}\text { Water Pressures } \\
\text { (PSIG) }\end{array}$} & \multirow{2}{*}{$\begin{array}{l}\text { Lower Seal } \\
\text { Water Fitow } \\
\text { (cchour) } \\
\text { (19) }\end{array}$} & \multirow{2}{*}{$\begin{array}{c}\text { LDCV Tan } \\
\text { Temp } \\
\left({ }^{\circ} \mathrm{F}\right) \\
(20)\end{array}$} \\
\hline & $\begin{array}{c}\text { Volts } \\
\text { (1) }\end{array}$ & \begin{tabular}{|c|} 
Amps \\
(2)
\end{tabular} & $\begin{array}{l}\text { RPM } \\
\text { (3) }\end{array}$ & $\begin{array}{l}\text { Intine } \\
\text { (4) }\end{array}$ & $\begin{array}{l}90^{\circ} \\
(5)\end{array}$ & $\begin{array}{l}\text { Axial } \\
\text { (6) }\end{array}$ & \begin{tabular}{|c|} 
Stator \\
(7)
\end{tabular} & \begin{tabular}{|c}
$\begin{array}{c}\text { Uppor } \\
\text { Bearing } \\
\text { (8) }\end{array}$ \\
\end{tabular} & \begin{tabular}{|c} 
Lower \\
Bearing \\
$(9)$
\end{tabular} & $\begin{array}{l}\text { Lower } \\
\text { (10) }\end{array}$ & $\begin{array}{l}\text { Uppor } \\
\text { (11) }\end{array}$ & $\begin{array}{l}\text { Thrust } \\
\text { (12) }\end{array}$ & $\begin{array}{l}\text { Upper } \\
\text { (13) }\end{array}$ & $\begin{array}{l}\text { Lower } \\
\text { (14) }\end{array}$ & $\begin{array}{c}\text { Upper Seal } \\
\text { Intet }[F] \\
(15)\end{array}$ & $\begin{array}{l}\text { Column } \\
\text { Vent } M \\
(16)\end{array}$ & $\begin{array}{l}\text { PCV } \\
\text { Outte? } \\
\text { (17) }\end{array}$ & $\begin{array}{l}\text { PCV } \\
\text { Inlet } \\
\text { (18) }\end{array}$ & & \\
\hline $4 / 17 / 968: 34$ & 297 & 1113.7 & 799.2 & 12.4 & 11.7 & 5.2 & 119.1 & 112.04 & 111.40 & .035 & .048 & .037 & 76.9 & 71.1 & 54 & 58 & 64 & 84 & $<34$ & 150 \\
\hline 4/17/96 9:02 & 296 & 113.0 & 799.2 & 12.3 & 11.5 & 6.1 & 120.3 & 112.07 & 111.44 & .041 & .043 & .036 & 77.0 & 71.0 & 56 & 60 & 62 & 82 & $<34$ & 150 \\
\hline $4 / 17 / 96 \quad 9: 35$ & 295 & .113 .5 & 798.9 & 12.4 & 11.7 & 5.8 & 120.1 & 112.08 & 111.47 & .035 & .048 & .038 & .77 .0 & 71.0 & 56 & 59 & 62 & 82 & $<34$ & 150 \\
\hline 4/17/96 10:05 & 297 & $\mathbf{1 1 3 . 5}$ & 798.9 & 12.5 & 11.3 & 6.1 & 120.1 & 112.13 & 111.51 & .045 & .043 & .038 & 77.5 & 71,1 & 55 & 60 & 64 & 82 & $<34$ & 158 \\
\hline 4/17/96 $\quad 10: 36$ & 296 & 113.5 & 799.2 & 12.4 & 11.8 & 5.9 & 119,3 & 112.18 & 111.56 & .042 & .039 & .037 & 77.6 & 71.5 & 55 & 60 & 64 & 80 & $<34$ & 159 \\
\hline $4 / 17 / 96 \quad 11: 02$ & 296 & 113.9 & 798.2 & 12,5 & 11.3 & 6.2 & 120.1 & 112.24 & 111.64 & .046 & .053 & .054 & 78.0 & 71.9 & 55 & 60 & 66 & 82 & $<34$ & 159 \\
\hline $4 / 17 / 96 \quad 11: 37$ & 296 & 113.3 & 798.9 & 12.7 & 11.5 & 6.1 & 120.4 & 112.30 & 111.70 & .035 & .053 & .029 & 78.3 & 71.9 & 56 & 61 & 66 & 82 & $<34$ & 159 \\
\hline 4/177/96 12:05 & 295 & 113.3 & 799.2 & 12.5 & 11.8 & 6.0 & 121.8 & 112.35 & 111.67 & .043 & .039 & .054 & 78.5 & 72.0 & 56 & 61 & 65 & 81 & $<34$ & 160 \\
\hline $4 / 17 / 96 \quad 12: 26$ & 295 & \begin{tabular}{|l|}
113.3 \\
\end{tabular} & 799.2 & 12.5 & 11.2 & 6.7 & 120.9 & 112.42 & 111.82 & .028 & .040 & .046 & 78.4 & 72.4 & 57 & 62 & 67 & 81 & $<34$ & 160 \\
\hline \multicolumn{21}{|l|}{$4417796 \quad 12: 42$} \\
\hline \multicolumn{21}{|l|}{ 4/177196 $12: 46$} \\
\hline $4 / 17796 \quad 13: 05$ & 296 & \begin{tabular}{|l|}
13.5 \\
\end{tabular} & 799.2 & 12.4 & 11.6 & 6.6 & \begin{tabular}{|l|}
121.4 \\
\end{tabular} & 112.47 & 111.89 & .027 & .031 & .049 & 79.0 & 72.5 & 57 & 62 & 67 & 82 & $<34$ & 165 \\
\hline 4/177/96 $13: 35$ & 295 & 113.3 & 799.2 & 12.05 & 11.0 & 6.5 & 121.7 & 112.55 & 111.95 & .026 & .031 & .046 & 79.1 & 72.6 & 58 & 62 & 70 & 95 & $<34$ & 165 \\
\hline $4 / 17 / 96 \quad 14: 05$ & 295 & 113.0 & 799.2 & 12.04 & 11.0 & 6.7 & 121,4 & $1+2.61$ & 112.01 & .037 & .042 & .023 & 79.5 & 73.1 & 58 & 63 & 70 & 95 & $<12$ & 170 \\
\hline $4 / 177 / 96614: 44$ & 297 & 113.0 & 799.2 & 12.10 & 11.2 & • & 121.7 & 112.7 & 112.10 & .035 & .045 & .054 & 80.0 & 73.6 & 58 & 63 & 70 & 72 & $<12$ & 170 \\
\hline 4/177/96 $\quad 15: 15$ & 297 & 113. & 799.2 & 12.12 & 11.6 & * & 122.0 & 112.77 & 112.16 & .027 & .037 & .039 & 80.2 & 73.5 & 58 & 62 & 70 & 95 & $<12$ & 171 \\
\hline $4 / 17 / 96 \quad 15: 45$ & 296 & 113.3 & \begin{tabular}{|l|}
799.2 \\
\end{tabular} & 12.3 & 12.0 & * & \begin{tabular}{l|l|}
122.4 \\
\end{tabular} & 112.81 & 112.19 & .024 & .032 & .065 & 80.4 & 73.7 & 55 & 58 & 63 & 96 & 300 & 170 \\
\hline 4/17/106 $\quad 16: 15$ & 296 & \begin{tabular}{|l|}
113.3 \\
\end{tabular} & 798.9 & 12.4 & 12.4 & $\cdot$ & 122.6 & 112.86 & 112.24 & .020 & .040 & .067 & 80.5 & 96.9 & 54 & 58 & 61 & 72 & 240 & 170 \\
\hline $4 / 177966 \quad 16: 45$ & 297 & 113.3 & \begin{tabular}{|l|}
799.2 \\
\end{tabular} & 12.3 & 12.4 & - & 122.3 & 112.89 & 112.26 & .027 & .038 & .048 & 80.5 & 96.9 & 55 & 59 & 61 & 95 & 300 & 170 \\
\hline $4 / 17796 \quad 17: 15$ & 296 & 113.3 & \begin{tabular}{|l|}
799.2 \\
\end{tabular} & 12.4 & 11.4 & * & 122.7 & 112.91 & 112.27 & .014 & .022 & .038 & 80.5 & 96.6 & 55 & 60 & 60 & 95 & 24 & 170 \\
\hline $4 / 17 / 96 \quad 17: 45$ & 295 & \begin{tabular}{|l|}
113.3 \\
\end{tabular} & 799.2 & 12.6 & 11.3 & - & 122.4 & 112.92 & 112.26 & .022 & .030 & .028 & 80.6 & 97.0 & 56 & 60 & 65 & 95 & 24 & 170 \\
\hline $4 / 17 / 96 \quad 18: 18$ & 297 & \begin{tabular}{|l|}
113.3 \\
\end{tabular} & \begin{tabular}{|l|l|}
799.2 \\
\end{tabular} & 12.4 & 11.4 & . & 122.4 & \begin{tabular}{|l|}
112.92 \\
\end{tabular} & 112.26 & .027 & .040 & .058 & 80.5 & 97.0 & 56 & 60 & 65 & 95 & 12 & 170 \\
\hline 4/17/196 $18: 45$ & 296 & 113.3 & 799.2 & 12.5 & 11.6 & * & 123.1 & $\{12.9$ & 112.23 & .018 & .030 & .015 & 80.6 & 97.6 & 56 & 61 & 65 & 95 & 12 & 170 \\
\hline $4 / 17 / 96 \quad 19: 15$ & 297 & 113.3 & 800.9 & 12.8 & 11.6 & * & 122.2 & 112.88 & 112,20 & .028 & .052 & .033 & 80.6 & 97.7 & 57 & 61 & 67 & 72 & $s$ & 170 \\
\hline 4/171966 19:45 & 296 & 113.3 & 800.9 & 12.3 & 11.7 & $\cdot$ & 122.6 & \begin{tabular}{|l|l|}
112.87 \\
\end{tabular} & 112.18 & .028 & .028 & .026 & 80.4 & 97.9 & 57 & 62 & 67 & 93 & 5 & 170 \\
\hline $4 / 17 / 96 \quad 20: 15$ & 296 & 113.5 & 800.9 & 12.3 & 11.5 & * & 122.7 & 112.8 & 112.2 & .039 & .050 & .094 & 80.6 & 98.4 & 58 & 62 & 68 & 93 & 3 & 170 \\
\hline $4 / 17 / 96 \quad 20: 45$ & 296 & 113.0 & 800.5 & 12.8 & 11.6 & $\cdot$ & 121.0 & 112.8 & 112.1 & .019 & .049 & .054 & 80.5 & 98.2 & 58 & 62.5 & 69 & 94 & 1.5 & 170 \\
\hline 4/17/96 21:15 & 296 & \begin{tabular}{|l|}
113.3 \\
\end{tabular} & 800.5 & 12.8 & 13.2 & * & 124.3 & 112.8 & 112.1 & .036 & .054 & .028 & 80.4 & 98.6 & 58 & 63 & 69 & 95 & 1.5 & 170 \\
\hline $4 / 17 / 196 \quad 21: 45$ & 296 & 113.3 & 800.5 & 10.9 & 13.8 & • & \begin{tabular}{|l|l|}
126.4 \\
\end{tabular} & 112.8 & $\$ 12.1$ & .024 & .043 & .019 & 80.3 & 98.3 & 58 & 63 & 70 & 73 & 1.5 & 170 \\
\hline 4/17/96 $22: 15$ & 296 & 113.5 & 800.5 & 11.5 & 13.6 & $\cdot$ & 121.9 & 112.8 & 112.1 & .033 & .042 & .088 & 80.1 & 98.5 & 59 & 64 & 71 & 94 & 1.5 & 172 \\
\hline 4/177/96 $22: 45$ & 296 & 113.3 & \begin{tabular}{|l|l|}
800.5 \\
\end{tabular} & 13.9 & 14.1 & * & 124.0 & 112.8 & 112.05 & .018 & .042 & .040 & 80.1 & 98.7 & 59 & 64 & 71 & 74 & 1.5 & 172 \\
\hline 4/17/96 $23: 15$ & 295 & 113.5 & 800.5 & 12.9 & 12.2 & - & 120.9 & 112.7 & 112.0 & .019 & .039 & .052 & 80.0 & 98.9 & 60 & 64 & 71 & $95^{\circ}$ & 1.5 & 172 \\
\hline $4 / 17 / 96 \quad 23: 45$ & 296 & 113.3 & \begin{tabular}{|l|l|}
800.5 & \\
\end{tabular} & 10.1 & 11.1 & * & 124.6 & 112.7 & 112.0 & .024 & .043 & .094 & 80.0 & 98.7 & 60 & 64 & 71 & 72 & 1.5 & 172 \\
\hline $4 / 181960015$ & 295 & 113.0 & 800.5 & 14.4 & 11.9 & $\cdot$ & 123.3 & 112.7 & $1+2.0$ & .027 & .041 & .065 & 79.9 & 98.9 & 60 & 64 & 71 & 96 & 1.5 & 172 \\
\hline $4 / 18 / 96 \quad 0045$ & 297 & 113.3 & \begin{tabular}{|l|}
800.9 \\
\end{tabular} & 11.5 & 13.1 & • & \begin{tabular}{|l|}
122.1 \\
\end{tabular} & 112.7 & 112.0 & .017 & .031 & .136 & 79.9 & 98.9 & 60 & 64 & 71 & 95 & 1.5 & 174 \\
\hline $4 / 18 / 96 \quad 0115$ & 297 & $\$ 112.7$ & 800.9 & 10.9 & 12.9 & * & 124.3 & 112.6 & 111.9 & .038 & .019 & .017 & 79.7 & 99.2 & 60 & 64 & 71 & 72 & 1.5 & 175 \\
\hline $4 / 181960145$ & 296 & \begin{tabular}{|l|}
113.0 \\
\end{tabular} & 800.9 & 10.5 & 9.8 & " & 122.7 & 112.6 & 111.9 & .019 & .040 & .067 & 79.6 & 99.4 & 60 & 64 & 71 & 96 & 1.5 & 175 \\
\hline $4 / 18 / 960215$ & 296 & \begin{tabular}{|l|}
113.5 \\
\end{tabular} & 800.9 & 9.1 & 10.2 & * & 120.3 & 112.6 & 111.9 & .024 & .052 & .094 & 79.5 & 100.0 & 60 & 64 & 71 & $9 \dot{5}$ & 1.5 & 175 \\
\hline $4 / 18 / 960245$ & 295 & 112.5 & 300.9 & 13.4 & 11.5 & • & 122.1 & 112.6 & 111.9 & .027 & .050 & .048 & 79.4 & 99.6 & 60 & 64 & 71 & 96 & 1.5 & 175 \\
\hline $4 / 18196 \quad 0315$ & 296 & $\mid 113.3$ & \begin{tabular}{|l|}
800.9 \\
\end{tabular} & 11.7 & 12.6 & - & 123.1 & 112.6 & 119 & .038 & .052 & .088 & 79.4 & 99.5 & 60 & 64 & 71 & 95 & 1.5 & 175 \\
\hline $4 / 18 / 96 \quad 0345$ & 296 & 113.5 & 800.9 & 12.2 & 14.3 & . & 122.1 & 112.6 & 111.9 & .026 & .032 & .033 & 79.3 & 100.0 & 60 & 64 & 71 & 90 & 1.5 & 175 \\
\hline
\end{tabular}


300 HP MIXER PUMP 90908-2 PERFORMANCE DEMONSTRATION TEST DATA SHEETS 400 AREA - MASF

\begin{tabular}{|c|c|c|c|c|c|c|c|c|c|c|c|c|c|c|c|c|c|c|c|c|}
\hline \multirow[t]{2}{*}{ Date Time } & \multicolumn{3}{|c|}{ Motor Loads } & \multicolumn{3}{|c|}{$\begin{array}{l}\text { Casing Vibrations } \\
\text { (Milliamps) }\end{array}$} & \multicolumn{3}{|c|}{$\begin{array}{l}\text { Motor Temperatures } \\
\qquad\left({ }^{\circ} \mathrm{F}\right)\end{array}$} & \multicolumn{3}{|c|}{$\begin{array}{c}\text { Motor Vibrations } \\
\text { (In/Sec) }\end{array}$} & \multicolumn{2}{|c|}{$\begin{array}{c}\text { Column Water } \\
\text { Temperatures } \\
\text { (' } \mathrm{F})\end{array}$} & \multicolumn{4}{|c|}{$\begin{array}{l}\text { Water Pressures } \\
\text { (PSIG) }\end{array}$} & \multirow{2}{*}{$\begin{array}{c}\text { Lower Sea! } \\
\text { Water Flow } \\
\text { (colhour) } \\
\text { (19) }\end{array}$} & \multirow{2}{*}{$\begin{array}{c}\text { LDCV Tank } \\
\text { Temp } \\
\left(^{\circ} \mathrm{F}\right) \\
(20)\end{array}$} \\
\hline & $\begin{array}{l}\text { Volts } \\
\text { (1) }\end{array}$ & $\begin{array}{c}\text { Amps } \\
\text { (2) }\end{array}$ & $\begin{array}{c}\text { RPM } \\
\text { (3) }\end{array}$ & $\begin{array}{l}\text { Inline } \\
\text { (4) }\end{array}$ & $\begin{array}{l}90^{\circ} \\
(5)\end{array}$ & $\begin{array}{l}\text { Axial } \\
\text { (6) }\end{array}$ & $\begin{array}{c}\text { Stator } \\
(7)\end{array}$ & $\begin{array}{c}\text { Upper } \\
\text { Bearing } \\
\text { (8) }\end{array}$ & $\begin{array}{c}\text { Lower } \\
\text { Bearing } \\
(9)\end{array}$ & $\begin{array}{l}\text { Lower } \\
(10)\end{array}$ & $\begin{array}{l}\text { Upper } \\
\text { (11) }\end{array}$ & $\begin{array}{l}\text { Thrust } \\
\text { (12) }\end{array}$ & $\begin{array}{l}\text { Upper } \\
\text { (13) }\end{array}$ & $\begin{array}{l}\text { Lower } \\
\text { (14) }\end{array}$ & $\begin{array}{l}\text { Upper Seal } \\
\text { Inlet [F] } \\
(15)\end{array}$ & $\begin{array}{l}\text { Column } \\
\text { Vent [V] } \\
(16)\end{array}$ & $\begin{array}{l}\text { PCV } \\
\text { Outiet } \\
\text { (17) }\end{array}$ & $\begin{array}{l}\text { PCV } \\
\text { Inlet } \\
(18)\end{array}$ & & \\
\hline $4 / 18 / 98$ o4t5 & 297 & 113.3 & 800.9 & 9.5 & 14.2 & $\bullet$ & 121.5 & 112.5 & 111.8 & .014 & .022 & .038 & 79.1 & 100.0 & 60 & 64 & 71 & 92 & 1.5 & 175 \\
\hline $4 / 18 / 960445$ & 297 & 112.7 & 800.9 & 11.3 & 13.7. & $*$ & 121.9 & 112.4 & 111.8 & .037 & .038 & .054 & 78.9 & 100.4 & 60 & 64 & 71 & 73 & 1.5 & 175 \\
\hline $4 / 18 / 96 \quad 0515$ & 297 & 113.6 & 800.9 & 10.7 & 8.3 & $\star$ & 118.9 & 112.4 & 111.8 & .028 & .047 & .067 & 78.9 & 100.0 & 60 & 64 & 71 & 95 & 1.5 & 175 \\
\hline $4 / 48 / 960545$ & 297 & 113.5 & 800.9 & & & & & & & & & & & & & & 71 & 90 & 1.5 & 175 \\
\hline $4 / 18 / 960615$ & 297 & 113.3 & 800.9 & 11.6 & 11.2 & $\star$ & 118.8 & 112.4 & 111.7 & .019 & .041 & .093 & 78.7 & 100.0 & 60 & 64 & 71 & 73 & 1.5 & 178 \\
\hline $4 / 18 / 960645$ & 296 & 113.5 & 800.9 & 11.8 & 13.7 & $\cdot$ & 121.3 & 112.3 & 111.7 & .036 & .035 & .017 & 78.4 & 100.0 & 60 & 64 & 71 & 95 & 1.5 & 179 \\
\hline $4 / 18 / 960715$ & 297 & 113.0 & 800.9 & 10.0 & 10.4 & - & 120.7 & 112.3 & 111.6 & 0.072 & 0.162 & 0.035 & 78.4 & 100.0 & 60 & 64 & 71 & 93 & 1.5 & 179 \\
\hline $4 / 18 / 960745$ & 296 & 113.3 & 800.9 & 12.7 & 12.5 & 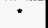 & 120.5 & 112.3 & 111.6 & 0.023 & 0.037 & 0.049 & 78.3 & 100.3 & 60 & 64 & 71 & 94 & 3 & 180 \\
\hline $4 / 18 / 960815$ & 296 & 113 & 200.9 & 11.5 & 12.3 & $\bullet$ & 120.3 & 112.3 & 111.6 & 0.021 & 0.04 & 0.025 & 78.2 & 100.5 & 60 & 64 & 71 & 72 & 1.5 & 180 \\
\hline $4 / 18 / 960854$ & \multicolumn{14}{|c|}{ SECURED WATER SUPPLY AND VENTED PUMP COLUMN WATER TO LDCV TANK WATER } & 60 & 64 & & & 0 & 178 \\
\hline $4 / 18 / 960902$ & \multicolumn{14}{|c|}{ CONTINUED TO VENT PUMP COLUMN WATER TO LDCV TANK } & 50 & 54.5 & & & $>2400$ & 178 \\
\hline $4 / 18 / 960948$ & 297 & 113.3 & 800.9 & 12.3 & 13.8 & $\star$ & 119.5 & 112.33 & 111.68 & .025 & .042 & .023 & 78.8 & 101.0 & $\$ 1$ & 56 & 63 & 74 & $>2400$ & 182 \\
\hline $4 / 18 / 961017$ & 296 & 113.0 & 800.0 & 11.7 & 12.5 & $\cdot$ & 121.5 & 112.40 & 111.76 & .023 & .037 & .024 & 79.0 & $10 t .0$ & 51 & 57 & 66 & 92 & $>2400$ & 182 \\
\hline 4/18/96 1045 & 297 & 113.3 & 800.9 & 12.2 & 12.8 & $*$ & 121.8 & 112.45 & 111.82 & .025 & .040 & .036 & 79.2 & 101.1 & 52 & 59 & 65 & 94 & 2400 & 182 \\
\hline $4 / 18 / 961115$ & 296 & 113.3 & 800.9 & 12.4 & 12.4 & - & 122.1 & 112.51 & 111.89 & .028 & .042 & .030 & 79.4 & 101.0 & 56 & 60 & 66 & 94 & 240 & 182 \\
\hline $4 / 18 / 96 \quad 1145$ & 295 & 113.3 & 800.9 & 12.8 & 13.1 & 4 & 122.8 & 112.56 & 111.94 & 0.025 & 0.038 & 0.038 & 79.4 & 101.2 & 56 & 60 & 68 & 94 & 36 & 185 \\
\hline $4 / 18 / 961218$ & 296 & 113.0 & 800.9 & 12.3 & 12.0 & $\bullet$ & +22.8 & 112.61 & 111.98 & .022 & .038 & .030 & 79.6 & 101.4 & 56 & 60.5 & 68.8 & 94 & 18 & 185 \\
\hline $4 / 18 / 961245$ & 296 & 113.3 & 800.9 & 12.8 & 11.8 & • & 122.5 & 112.64 & 112.04 & .025 & .034 & .034 & 79.9 & 101.7 & 56 & 60.5 & 68.5 & 92 & 9 & 485 \\
\hline $4 / 18 / 96 \quad 1315$ & 296 & 113.3 & 800.9 & 12.7 & 12.5 & $\bullet$ & 123.1 & 112.67 & 112.04 & .028 & .040 & .036 & 79.9 & 101.9 & 56 & 60.5 & 68.5 & 90 & 9 & 185 \\
\hline $4 / 18 / 96 \quad 1345$ & 297 & 113.3 & 800.9 & 12,6 & 12.4 & 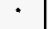 & 122.4 & 162.70 & 112.10 & .028 & .036 & .032 & 80.3 & 102.0 & 56 & 60.5 & 69 & 72 & 9 & 185 \\
\hline $4 / 18 / 96$ 1415 & 296 & 113.3 & 800.9 & 12.3 & 12.3 & $*$ & 122,7 & 112.77 & 112.15 & .021 & .037 & .024 & 80.5 & 102.4 & 56 & 60.5 & 70 & 74 & 9 & 185 \\
\hline $4 / 18 / 961443$ & 297 & 113.3 & 800.9 & 12.6 & 12.7 & $*$ & 123.4 & 112.81 & 112.18 & .019 & .030 & .027 & 80,7 & 102.4 & 56 & 61 & 69 & 74 & 0 & 187 \\
\hline $4 / 18 / 961445$ & & & & & & & & & & & & & & & & 57 & & & 0 & 185 \\
\hline $4 / 18 / 961515$ & 297 & 113.3 & 801.2 & 11.5 & 11.9 & $*$ & 123.7 & 112.87 & 112.23 & .027 & .042 & .032 & 81.0 & 102.6 & 52 & 58 & 67 & 72 & 0 & 187 \\
\hline $4 / 18 / 96 \quad 1545$ & 296 & 113.3 & 800.9 & 11.8 & 11.9 & $*$ & 123.3 & 112.90 & 112.25 & 0.024 & 0.031 & 0.036 & 81.1 & 102.7 & 54 & 58 & 67 & 94 & 0 & 187 \\
\hline $4 / 18 / 961611$ & 296 & 113.3 & 8009 & 12.1 & 11.5 & $*$ & 123.3 & 112.93 & 112.27 & 0.018 & 0.032 & 0.039 & 81.0 & 102.8 & 54 & 58 & 67 & 94 & 0 & 187 \\
\hline $4 / 19 / 960902$ & 0 & 0 & 0 & 0 & 0 & . & 68.3 & 109.90 & 108.96 & 0 & 0 & 0 & 70.5 & 91.4 & 42 & 46 & 55 & 70 & 0 & 171 \\
\hline $4 / 19 / 961135$ & 0 & 0 & 0 & 0 & 0 & INIT & IATED F & $E E D \& B L$ & EED & & & & & & & & & & & \\
\hline $4 / 19 / 961300$ & 0 & 0 & 0 & 0 & 0 & & PUMP & OFF-COL & UMN FLO & W SECU & RED-FEE & OING \& 8 & EEDING & & & & & & & \\
\hline $4 / 19 / 961305$ & 0 & 0 & 0 & 0 & 0 & $*$ & & & & & & & 71.0 & 90.5 & 38 & 42 & 51 & 78 & 0 & 160 \\
\hline $4 / 19196 \quad 1307$ & 0 & 0 & 0 & 0 & 0 & & & OPPED FE & EDO \& BLE & ED \& IN & TATED & OLUMN F & LOW & & & & & & & \\
\hline 4/19/ses t405 & 0 & 0 & 0 & 0 & 0 & & STEM C & OOL DOW & WN / LEFT & IN THIS & CONDIT & & 70.9 & 89.7 & 56 & 60 & 63 & 95 & 420 & 159 \\
\hline 4/19/96 1839 & 0 & 0 & 0 & 0 & 0 & $*$ & & & & & & & 70.9 & 87.9 & 55.5 & 60 & 63 & 95 & 360 & 150 \\
\hline
\end{tabular}




\begin{tabular}{|c|c|c|c|c|c|c|c|c|c|c|c|c|c|c|}
\hline & g'gst & 0 & 26 & $56 s$ & LS & $\angle v$ & $9 ' 901$ & $6^{\prime} 18$ & $\angle Z Z I L$ & $9 \varepsilon 41$ & g'6t6 & $605 \mathrm{~L}$ & $05 \varepsilon$ & 0091 \\
\hline & L'bGL & 0 & \$6 & 89 & $0 s$ & st & SOL & 9.18 & $9 \mathrm{zll}$ & 9ELL & $16 b 6$ & $z$ Isı & $05 \varepsilon$ & oost \\
\hline & 9'Zsl & 0 & 86 & 89 & 80 & Et & z $\mathrm{col}$ & 918 & szll & sent & S'6.6 & LเSเ & $09 \varepsilon$ & $000 t$ \\
\hline & $90 S 1$ & 0 & 56 & 99 & 96 & $\varepsilon$ & $\varepsilon z O L$ & $\angle 08$ & $\varepsilon z l b$ & tr\& & $8^{\prime} 616$ & $\tau^{\prime \prime I S l}$ & $09 \varepsilon$ & $00 \varepsilon l$ \\
\hline & S'stl & 0 & 96 & s9 & $9 t$ & $\varepsilon t$ & I'LOL & 908 & $t z l k$ & $\nabla \varepsilon L$ & 1666 & S'LSเ & $0 \varsigma \varepsilon$ & $00 z 6$ \\
\hline & $\varepsilon 9 t /$ & 0 & 56 & $\not S$ & st & $8 \varepsilon$ & 566 & 808 & vzlk & s\&ll & 9606 & PISI & $6 \leftarrow \varepsilon$ & 0011 \\
\hline & $\varepsilon \omega$ & 0 & 26 & $p s$ & st & $8 \varepsilon$ & 186 & 908 & 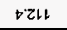 & $\supset \varepsilon$ & S'6b6 & $\tau$ เงเ & $0 S \varepsilon$ & 0001 \\
\hline & t'ztl & 0 & $\forall L$ & 29 & $\varepsilon t$ & $8 \varepsilon$ & 126 & 908 & EZLL & SELL & $s_{6+6}$ & s'sts & $05 \varepsilon$ & 0060 \\
\hline & rotl & 0 & 26 & is & $\varepsilon$ & $8 \varepsilon$ & 106 & 908 & EZIL & $\varepsilon \varepsilon H$ & S'6t6 & I'ZSl & $6 t \varepsilon$ & 0080 \\
\hline & $\tau^{\prime} 8 \varepsilon \ell$ & 0 & 26 & LS & $z$ & $\angle \varepsilon$ & 626 & 608 & ZZZLL & gell & $66 \mathrm{b6}$ & 8.19L & OGE & $00 \angle 0$ \\
\hline & l'sEl & 0 & 26 & $\alpha s$ & $z$ & $8 \varepsilon$ & 886 & 508 & EZIL & $\nabla \varepsilon H$ & 8656 & LISL & os $\varepsilon$ & 0090 \\
\hline & $|\cdot \varepsilon \varepsilon|$ & 0 & 96 & $0 s$ & $L t$ & $\Sigma \varepsilon$ & $\varepsilon 6$ & 808 & bZIL & $\nabla \varepsilon \varepsilon L L$ & 8625 & S'ISL & $z \varsigma \varepsilon$ & 0090 \\
\hline & 6081 & 0 & $2 L$ & $6 t$ & Lt & $9 \varepsilon$ & 26 & 18 & $5 \mathrm{Zll}$ & sell & 8656 & DZSı & $05 \varepsilon$ & $00+0$ \\
\hline & $2 \cdot 8 z I$ & 0 & 16 & $8 t$ & ot & $9 \varepsilon$ & $z^{\prime} \cdot 6$ & L'18 & t'Z1L & g'El। & 8676 & D.2St & $0 s \varepsilon$ & $00 \varepsilon 0$ \\
\hline & s'szl & 0 & 86 & $S L t$ & 568 & $\varsigma \varepsilon$ & 906 & 28 & 9ZIL & gett & 8606 & $\nabla 2 s i$ & เSE & $00 z 0$ \\
\hline & 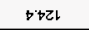 & 0 & $z L$ & $\angle t$ & $6 \varepsilon$ & $\varsigma \varepsilon$ & 868 & $5 ' 28$ & $\angle Z H L$ & $8 . \varepsilon 1$ & 8666 & $\angle Z S I$ & เפE & 0010 \\
\hline & s'\&Zl & 0 & 86 & $9 v$ & $8 \varepsilon$ & $\varepsilon \varepsilon$ & $\angle 88$ & 678 & $8 \mathrm{ZLL}$ & $6 \varepsilon \mathrm{Lt}$ & $86 \$ 6$ & t'Zsi & $0 \varsigma \varepsilon$ & $0000 \mathrm{tZ/G}$ \\
\hline & $\downarrow \cdot \mid z \downarrow$ & 0 & $2 L$ & sst & $5<\varepsilon$ & $\varepsilon \varepsilon$ & 6288 & s६8 & Et. & LOLt & 8676 & $\S g l$ & OSE & $00 \varepsilon z$ \\
\hline & $58+1$ & 0 & $z L$ & st & $2 \varepsilon$ & $2 \varepsilon$ & $1 \cdot 28$ & L.t8 & ZELL & $\varepsilon b u l$ & 8666 & 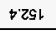 & $0 \varsigma \varepsilon$ & $00 z z$ \\
\hline & s9rl & 0 & 96 & $s t$ & 998 & $\tau \varepsilon$ & 998 & $7+68$ & $\varepsilon \varepsilon$ & $\varepsilon p 11$ & $s 6+6$ & $\varepsilon \varepsilon s$ & $0 \subseteq \varepsilon$ & 0012 \\
\hline & $\varepsilon \forall t$ & 0 & $z L$ & to & s'९६ & $z \varepsilon$ & $\$ \$ 8$ & sts & E'EเL & $\varepsilon ' t h$ & S'6t6 & $\varepsilon s L$ & $0 \varsigma \varepsilon$ & $000 z$ \\
\hline & 241 & 0 & 26 & $\varepsilon t$ & $9 \varepsilon$ & $\llcorner\varepsilon$ & $c \triangleright 8$ & 58 & $\varepsilon \varepsilon i l$ & $\varepsilon b l$ & $5 \in t 6$ & $\angle \mathrm{CSl}$ & $0 \varsigma \varepsilon$ & $006 \mathrm{~L}$ \\
\hline & 6601 & 0 & 76 & $\varepsilon t$ & s૬ع & $\downarrow \varepsilon$ & $\mathrm{s} \varepsilon$ & ॰६६ & IEIL & LDH & 9616 & s૬l & $0 \subseteq \varepsilon$ & 0081 \\
\hline & 801 & 0 & $\varepsilon 6$ & $2 b$ & $\varsigma \varepsilon$ & $0 \varepsilon$ & $\angle ' Z 8$ & 928 & $8 \mathrm{ZIL}$ & $8 \& L L$ & $28+8$ & $\varepsilon 9 z$ & $t i \varepsilon$ & $00 \angle L$ \\
\hline & $\varepsilon 90$ & 0 & $z L$ & $z$ & $\mathrm{~s} \varepsilon$ & $8 z$ & 1.28 & 918 & $\angle Z l k$ & 9Eमा & $6 \mapsto 8$ & s'LZI & $p 1 \varepsilon$ & $009 l$ \\
\hline & sol & 0 & S6 & sto & $s t \varepsilon$ & $8 z$ & $t 18$ & 18 & $9 \mathrm{zIL}$ & SELL & $28+8$ & S.LZL & $t 1 \varepsilon$ & oogl \\
\hline & seot: & 0 & $9 L$ & sits & $b \varepsilon$ & $8 z$ & 908 & $\rightarrow 08$ & szll & $\varepsilon \varepsilon$ & $\angle 8+8$ & $z " 8 z l$ & $t i \varepsilon$ & $00+1$ \\
\hline & stot & 0 & Do & 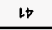 & $\nabla \varepsilon$ & $8 z$ & 762 & 862 & $\varepsilon z H$ & z'EH & $6+8$ & $8: \angle Z I$ & $\nabla 1 \varepsilon$ & $00 \varepsilon 1$ \\
\hline & 866 & 0 & $z L$ & $t$ & s"ع & $8 z$ & +82 & GL & $\varepsilon z 1 L$ & $\varepsilon L$ & Lot8 & $L Z L$ & $t 1 \varepsilon$ & $00 Z L$ \\
\hline & 286 & 0 & $\varepsilon L$ & it & $\mathbf{s} \varepsilon \varepsilon$ & $8 z$ & $\varepsilon \angle L$ & $18 L$ & IZIl & $8 \mathrm{ZLL}$ & $\angle 8+8$ & $\angle z l$ & $\nabla 1 \varepsilon$ & 0011 \\
\hline & 896 & 0 & 16 & it & $\Sigma$ & $8 z$ & +92 & $L L$ & $6.11 \mathrm{H}$ & 9ZLL & $6+8$ & $\varepsilon^{\prime} \measuredangle z l$ & 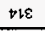 & $000 \mathrm{~L}$ \\
\hline & 196 & L'GLO & $\varepsilon 6$ & tt & $\varepsilon \varepsilon$ & $8 z$ & $9+2$ & $\nabla t b L$ & Zlll & efu & $6 \mapsto 8$ & s'Lzl & $\uparrow 1 \varepsilon$ & 0060 \\
\hline & 176 & 0 & 96 & $t$ & 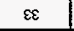 & $8 Z$ & $\nabla i$ & $\varepsilon^{\prime} \varepsilon L$ & LOHL & 9.1H & $96+8$ & s:LzI & $\nabla 1 \varepsilon$ & 0580 \\
\hline & $\varepsilon \$ 6$ & 0 & $\varepsilon 6$ & Lt & s'ze & $8 z$ & $\iota \varepsilon L$ & s.l & 9011 & 6.011 & L'866 & $\varepsilon^{\prime} 891$ & $\angle S \varepsilon$ & 0080 \\
\hline & 826 & 0 & t6 & it & $s z \varepsilon$ & 82 & $\varepsilon L$ & 802 & Eolk & boll & $\angle 866$ & $\varepsilon 89 l$ & $\angle 9 \varepsilon$ & $S \triangleright L O$ \\
\hline & 1.26 & 0 & 96 & 200 & 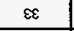 & $o \varepsilon$ & $9 Z 2$ & 969 & 9601 & 9601 & 9866 & 8.291 & $89 \varepsilon$ & $0 \varepsilon \angle 0$ \\
\hline & - & - & - & - & - & - & - & - & - & - & 2866 & $1.0 \angle L$ & $29 \varepsilon$ & $02 \angle 0$ \\
\hline & 1.26 & 0 & 26 & sot & s'ze & $8 z$ & $\rightarrow 2 L$ & 889 & $z 60 t$ & l.60l & 8662 & 6HL & 962 & $20 \angle 0$ \\
\hline & $\nabla 16$ & $\nabla 0$ & $\varepsilon 6$ & SOD & s. & $8 z$ & $\$ Z L$ & 189 & $\angle 801$ & $\angle 801$ & S'L6ع & $\varepsilon 99$ & $80 \mathrm{~b}$ & $\angle S 9 O$ \\
\hline & pit6 & 60 & $\varepsilon L$ & sot & S'lદ & 82 & $z L$ & 89 & $980 \mathrm{t}$ & L'801 & 66 & 969 & ob & 1990 \\
\hline & $t-16$ & 0 & 96 & sob & sile & $6 z$ & $z L$ & 920 & 9801 & 8801 & 0 & 0 & 0 & $\varepsilon Z 90$ 96roZs \\
\hline \multirow{2}{*}{ spuaturuos } & \multirow{2}{*}{$\begin{array}{c}(0 z) \\
\left(s_{0}\right) \\
d w \theta_{\perp} \\
\times u_{0} \perp \wedge 07\end{array}$} & \multirow{2}{*}{ 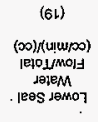 } & 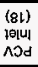 & $\begin{array}{l}(L b) \\
\text { tolyo } \\
\text { ADd }\end{array}$ & $\begin{array}{c}\text { (ow) } \\
\text { W vien } \\
\text { ueumos }\end{array}$ & $\begin{array}{c}\text { (SL) } \\
\text { Ifl leiu| } \\
\text { lees loddn }\end{array}$ & $\begin{array}{l}(\$ L) \\
\text { دөмо7 }\end{array}$ & $\begin{array}{l}(\varepsilon \downarrow) \\
\text { ləddn }\end{array}$ & $\begin{array}{c}(6) \\
\text { 6uldeog } \\
\text { semo7 }\end{array}$ & $\begin{array}{c}\text { (8) } \\
\text { Guteog } \\
\text { Jaddn }\end{array}$ & $\underset{\text { Wdy }}{(\varepsilon)}$ & $\begin{array}{l}\text { (z) } \\
\text { sousy }\end{array}$ & $\begin{array}{l}\text { (1) } \\
\text { sion }\end{array}$ & \multirow{2}{*}{ 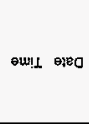 } \\
\hline & & & \multicolumn{4}{|c|}{$\begin{array}{c}\text { (olsd) } \\
\text { semsรa)d Jelem }\end{array}$} & \multicolumn{2}{|c|}{$\begin{array}{c}\left(J_{0}\right) \\
\text { sennesadured } \\
\text { Jəlem uunjos }\end{array}$} & \multicolumn{2}{|c|}{ 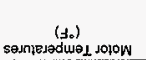 } & \multicolumn{3}{|c|}{ speof Jo3oW } & \\
\hline
\end{tabular}


300 HP MIXER PUMP 90908-1 PERFORMANCE DEMONSTRATION TEST DATA SHEETS 400 AREA - MASF

\begin{tabular}{|c|c|c|c|c|c|c|c|c|c|c|c|c|c|c|}
\hline \multirow{2}{*}{ Date Time } & \multicolumn{3}{|c|}{ Motor Loads } & \multicolumn{2}{|c|}{$\begin{array}{l}\text { Motor Temperatures } \\
\left({ }^{\circ} \mathrm{F}\right)\end{array}$} & \multicolumn{2}{|c|}{$\begin{array}{c}\text { Column Water } \\
\text { Temperatures } \\
\left.\text { ( }{ }^{\circ} \mathrm{F}\right)\end{array}$} & \multicolumn{4}{|c|}{$\begin{array}{l}\text { Water Pressures } \\
\text { (PSIG) }\end{array}$} & \multirow{2}{*}{$\begin{array}{c}\text { Lower Seal } \\
\text { Water } \\
\text { Flow/Total } \\
\text { (colmin)/(co) } \\
\text { (19) }\end{array}$} & \multirow{2}{*}{$\begin{array}{c}\text { LDCV Tank } \\
\text { Temp } \\
\text { (ㄷ) } \\
\text { (20) }\end{array}$} & \multirow[t]{2}{*}{ Comments } \\
\hline & $\begin{array}{l}\text { Volts } \\
\text { (1) }\end{array}$ & $\begin{array}{l}\text { Amps } \\
(2)\end{array}$ & $\underset{(3)}{R P M}$ & $\begin{array}{l}\text { Upper } \\
\text { Bearing } \\
\text { (8) }\end{array}$ & $\begin{array}{l}\text { Lower } \\
\text { Bearing } \\
\text { (9) }\end{array}$ & $\begin{array}{l}\text { Upper } \\
\text { (13) }\end{array}$ & $\begin{array}{l}\text { Lower } \\
\text { (14) }\end{array}$ & $\begin{array}{c}\text { Upper Seal } \\
\text { Inlet [F] } \\
(15)\end{array}$ & $\begin{array}{l}\text { Column } \\
\text { Vent [M] } \\
(16)\end{array}$ & $\begin{array}{l}\text { PCV } \\
\text { Outlet } \\
(17)\end{array}$ & $\begin{array}{l}\text { PCV } \\
\text { Intet } \\
(18)\end{array}$ & & & \\
\hline 1700 & 350 & 150.9 & 949.5 & 113.7 & $t 12.7$ & 82.3 & 108 & 48 & 52 & 60.5 & 94 & 0 & 158.1 & \\
\hline 1800 & 350 & 151.5 & 949.8 & 113.8 & 112.8 & 82.9 & 109.8 & 49 & 53 & 62 & 94 & 0 & 160.2 & \\
\hline 1900 & 350 & 151.2 & 949.5 & 113.9 & 112.9 & 83.1 & 111.5 & 51 & 55 & 63 & 90 & 0 & 162.1 & \\
\hline 2000 & 350 & 150.9 & 949.5 & 113.9 & 112.9 & 83.1 & 113.1 & 52 & 56 & 64.5 & 72 & 0 & 163.8 & \\
\hline 2100 & 350 & 150.5 & 949.5 & 113.8 & 112.8 & 83 & 114.9 & 53 & 57 & 66 & 72 & 0 & 165.7 & \\
\hline 2200 & 350 & 150.5 & 949.5 & 113.7 & 112.6 & 82.6 & 117 & 54 & 58 & 67 & 98 & $0 / 90.3$ & 167.3 & . \\
\hline 2300 & 350 & 150.9 & 849.8 & 113.7 & 112.6 & 82.4 & 118.4 & 55 & 60 & 68 & 98 & $0 / 92.0$ & 169.3 & \\
\hline $5 / 220000$ & 350 & 150.5 & 349.5 & 113.6 & 112.6 & 82.1 & 120.6 & 57 & 61.5 & 70 & 96 & 0 & 170.7 & \\
\hline 0100 & 350 & 150.9 & 949.5 & 113.5 & 112,5 & 82.1 & 122.5 & 58 & 62.5 & 71 & 94 & $0 / 96.2$ & 172.1 & \\
\hline 0200 & 350 & 149.8 & 949.5 & 113.5 & 112.5 & 82 & 124.6 & 59 & 64 & 72 & 93 & $0 / 98.1$ & 173.8 & \\
\hline 0300 & 350 & 150.5 & 949.5 & 113.5 & 112.5 & 81.9 & 126.4 & 58 & 62.5 & 71 & 96 & $0 / 100.2$ & 175.5 & \\
\hline 0.400 & 351 & 150.9 & 949.5 & 113.4 & 112.4 & 82 & 129.3 & 57.5 & 62 & 71 & 72 & $0 / 102.1$ & 177.1 & \\
\hline 0500 & 351 & 150.5 & 949.5 & 113.4 & 112.4 & 81.9 & 131 & 57 & 61.5 & 70 & 72 & $0 / 103.9$ & 178.4 & \\
\hline 0600 & 350 & 150.5 & 949.5 & $1 \mathrm{t} 3.4$ & 112,4 & 81.7 & 133.4 & 57 & 61 & 70 & 98 & o/t05.6 & 180.4 & \\
\hline 0700 & 350 & 151.2 & 949.5 & 113.4 & 112.3 & 81.8 & 135.8 & 57 & 61 & 70 & 95 & $0 / 107.4$ & 182.4 & \\
\hline 0800 & 350 & 150.2 & 949.8 & 113,4 & 112.4 & 82 & 138.3 & 61 & 61 & 70 & 76 & $0 / 109.0$ & 184.4 & \\
\hline 0900 & 350 & 150 & 949.5 & 113.4 & 112.4 & 82.4 & 140.8 & 56 & 60 & 70 & 95 & $0 / 110.7$ & 185.9 & \\
\hline 1000 & 350 & 149 & 949.5 & 113.5 & 112.5 & 82.7 & 143.4 & 56 & 60 & 69.5 & 90 & $0 / 112.1$ & 187.3 & \\
\hline 1100 & 350 & 149.8 & 949.8 & 113.5 & 112.6 & 83 & 114.4 & 56 & 60 & 69.5 & 73 & $0 / 113.7$ & 188.8 & \\
\hline 1145 & 351 & 149.4 & 949.5 & 113.6 & 112.6 & 83 & 146.8 & 56 & 61 & 69.5 & 94 & $0 / 115.2$ & 190 & \\
\hline 1215 & 350 & 150 & 949.5 & 113.6 & 112.6 & 83.2 & 147.4 & 56 & 61 & 69.5 & 72 & $0 / 115.9$ & 190.6 & \\
\hline 1245 & 350 & 148.8 & 949.5 & 113.6 & 112.6 & 83.4 & 148.8 & 56 & 61 & 69.5 & 72 & $0 / 116.7$ & 191.3 & \\
\hline 1315 & 350 & 150.5 & 949.5 & 113.6 & 112,6 & 83.6 & 150 & 56 & 61 & 69.5 & 73 & $0 / 117.6$ & 192.1 & \\
\hline 1345 & 350 & 149.4 & 949.5 & 113.7 & 112.7 & 83.5 & 151.9 & 56 & 61 & 69.5 & 72 & $0 / 118.3$ & 192.9 & \\
\hline 1415 & 350 & 150.5 & 949.8 & 113.7 & 112.7 & 83.5 & 152.5 & 56 & 60 & 69.5 & 94 & $0 / 119.0$ & 193.7 & \\
\hline 1445 & 350 & 151.2 & 949.8 & 113.7 & 112.7 & 83.6 & 153.5 & 56 & 60 & 70 & 72 & $0 / 120.0$ & 194,4 & \\
\hline 1515 & 350 & 151.3 & $\$ 49.7$ & 113.7 & 112.7 & 83.8 & 153.7 & 56 & 60 & 70 & 95 & $0 / 120.9$ & 195.2 & \\
\hline 1545 & 350 & 151.2 & 949.5 & 113.7 & 112.6 & 83.8 & 155.3 & 56 & 60 & 70 & 98 & $0 / 121.7$ & 195.9 & \\
\hline 1615 & 350 & 151.5 & $\$ 49.8$ & 113.7 & 112.6 & 83.9 & 155.9 & 56 & 60 & 70 & 95 & $0 / 122.5$ & 196.7 & \\
\hline 1645 & 350 & 151 & 949.5 & 113.7 & 112.6 & 84.3 & 156.3 & 56 & 60 & 70 & 96 & $0 / 123.4$ & 197.4 & \\
\hline 1715 & 350 & 150.2 & 949.8 & 113.7 & 112.7 & 84.3 & 157.1 & 56 & 60 & 70 & 98 & $0 / 124.3$ & 198 & \\
\hline 1740 & 350 & 151.2 & 949.8 & 113.7 & 112.7 & 84.8 & 157.3 & 56 & 60 & 70 & 72 & $0 / 125$ & 188.5 & \\
\hline 1742 & 376 & 170.1 & 1020.1 & 113.8 & 112.7 & 84.8 & 158.1 & 56 & 60 & 70 & 94 & $0 / 125.1$ & 198.5 & \\
\hline 1757 & 376 & 169.8 & 1020.2 & 113.9 & 112.8 & 84.8 & 158.5 & 56 & 60 & 70 & 92 & $0 / 125.5$ & 199 & \\
\hline 1812 & 376 & 169.5 & 1020.1 & 113.9 & 112.7 & 84.8 & 158.5 & 56 & 60 & 70 & 94 & $0 / 126$ & 199.5 & \\
\hline 1827 & 376 & 169.9 & 1019.9 & 114.1 & 112.9 & 84.8 & 158.6 & 56 & 60 & 70 & 92 & 0/126.4 & 199.9 & \\
\hline 1842 & 376 & 170.2 & 1020.4 & 114.2 & 113.1 & 84.8 & 158.7 & 56 & 60 & 70 & 94 & $0 / 126.8$ & 200.3 & \\
\hline 1945 & 295 & 113.2 & 799.2 & 113.8 & 112.7 & 84.3 & 157.8 & 56 & 60 & 68 & 94 & $0 / 128.7$ & 200.5 & \\
\hline 2045 & 294 & 113.8 & 799.2 & 113.7 & 112.6 & 84.3 & 105.3 & 54 & 58 & 66 & 97 & $0 / 130.5$ & 200.8 & \\
\hline 2145 & 295 & 113.9 & 799.3 & 113.5 & 112.5 & 83.6 & 97.5 & 52 & 56 & 65 & 97 & $0 / 132.2$ & 200.4 & \\
\hline 2245 & 277 & 104.9 & 750 & 113.5 & 112.6 & 83.6 & 96.4 & 49 & 54 & 63 & 97 & $0 / 133.8$ & 201.5 & \\
\hline
\end{tabular}




\section{HP MIXER PUMP 90908-1 PERFORMANCE DEMONSTRATION TEST DATA SHEETS 400 AREA - MASF}

\begin{tabular}{|c|c|c|c|c|c|c|c|c|c|c|c|c|c|c|}
\hline \multirow{2}{*}{ Date Time } & \multicolumn{3}{|c|}{ Motor Loads } & \multicolumn{2}{|c|}{$\begin{array}{l}\text { Motor Temperatures } \\
\left({ }^{\circ} \mathrm{F}\right)\end{array}$} & \multicolumn{2}{|c|}{$\begin{array}{c}\text { Column Water } \\
\text { Temperatures } \\
\left.\text { ( }{ }^{\circ} \mathrm{F}\right)\end{array}$} & \multicolumn{4}{|c|}{$\begin{array}{c}\text { Water Pressures } \\
\text { (PS|G) }\end{array}$} & \multirow{2}{*}{$\begin{array}{c}\text { Lower Seal } \\
\text { Water } \\
\text { Flow/Total } \\
\text { (co/min)/(co) } \\
\text { (19) }\end{array}$} & \multirow{2}{*}{$\begin{array}{c}\text { LDCV Tank } \\
\text { Temp } \\
\left({ }^{\circ} \mathrm{F}\right) \\
(20)\end{array}$} & \multirow[t]{2}{*}{ Comments } \\
\hline & $\begin{array}{l}\text { Volts } \\
\text { (1) }\end{array}$ & $\begin{array}{l}\text { Amps } \\
\text { (2) }\end{array}$ & $\begin{array}{l}\text { RPM } \\
(3)\end{array}$ & $\begin{array}{l}\text { Upper } \\
\text { Bearing } \\
\text { (8) }\end{array}$ & $\begin{array}{l}\text { Lowet } \\
\text { Bearing } \\
(9)\end{array}$ & $\begin{array}{l}\text { Upper } \\
\text { (13) }\end{array}$ & $\begin{array}{l}\text { Lower } \\
\text { (14) }\end{array}$ & $\begin{array}{l}\text { Upper Soal } \\
\text { Inlet [F] } \\
\text { (15) }\end{array}$ & $\begin{array}{l}\text { Column } \\
\text { Vent [V] } \\
(16)\end{array}$ & $\begin{array}{c}\text { PCV } \\
\text { Outlet } \\
(17)\end{array}$ & $\begin{array}{l}\text { PCV } \\
\text { Inlet } \\
(18)\end{array}$ & & & \\
\hline 2345 & 278 & 104.6 & 750 & 113.4 & 112.5 & 83.4 & 94.3 & 45 & 51 & 60 & 97 & $0 / 135.6$ & 200.1 & \\
\hline 9605230045 & 277 & 104.9 & 750 & 113.1 & 112.3 & 82.9 & 91.8 & 45 & 50 & 58 & 72 & $0 / 137.5$ & 199.7 & \\
\hline 0145 & 278 & 104.7 & 750 & 113.1 & 112.2 & 82.6 & 89.5 & 44 & 48 & 56 & 72 & o/139.3 & 199.6 & \\
\hline 0245 & 277 & 104.6 & 750 & 113 & 112.1 & 82 & 86.5 & 43 & 47 & 55 & 93 & $0 / 140.9$ & 199.5 & \\
\hline 0345 & 278 & 104.9 & 750 & 112.9 & 112 & 81.7 & 88.7 & 42 & 46 & 54 & 93 & $0 / 142.6$ & 199,2 & \\
\hline 0445 & 279 & 104.9 & 750 & 112.9 & 112 & 81.4 & $*$ & 41 & 45 & 54 & 98 & $0 / 144.6$ & 198.7 & \\
\hline 0545 & 277 & 105.2 & 750 & 112.9 & 111.9 & 81 &. & 40 & 44.5 & 53 & 72 & $0 / 146.1$ & 198.5 & \\
\hline 0645 & 277 & 105.2 & 750 & 112.8 & 111.9 & 80.7 & 83.4 & 39.5 & 43 & 52 & 94 & $0 / 147.9$ & 198.7 & \\
\hline 0745 & 277 & 104.9 & 750 & 112.8 & 111.9 & 80.7 & 81.4 & 39 & 42 & 51 & 72 & $0 / 149.6$ & 200 & \\
\hline 0845 & 277 & 104.9 & 750 & 112.9 & 112 & 81.3 & - & 38 & 43 & 51 & 75 & $0 / 151.8$ & 199.1 & \\
\hline 0945 & 277 & 105.1 & 750 & 113 & 112.1 & 81.5 & $\bullet$ & 38 & 42 & 50 & 94 & $0 / 152.9$ & 193.2 & \\
\hline 1045 & 277 & 104.9 & 750 & 113 & 112.1 & 81.5 & • & 36 & 40 & 48 & 72 & $0 / 154.6$ & +92.1 & \\
\hline 1145 & 277 & 105.2 & 750 & 113.1 & 112.2 & 82 & 90.5 & 35 & 40 & 47.5 & 72 & $0 / 156.4$ & 192.1 & \\
\hline 1215 & 277 & 104.9 & 750 & 113.2 & 1123 & 82.2 & 100.5 & 33 & 38.5 & 46 & 58 & $0 / 157.3$ & 788.1 & \\
\hline 1245 & 277 & 105.5 & 750 & 113.2 & 112.3 & 82.2 & 99.1 & 33 & 38 & 45 & 92 & $0 / 158.1$ & 186.7 & \\
\hline 1305 & 277 & 105.2 & 750 & 113.3 & 112.3 & 82.2 & 98.8 & 33 & 37.5 & 45 & 93 & $0 / 158.8$ & 186.3 & \\
\hline 1459 & 0 & 0 & 0 & $\cdots$ & -- & - & - & 31.5 & 36 & 44 & 93 & $0 / 162.5$ & 184,3 & \\
\hline 1606 & 0 & $?$ & 0 & . & - & - & - & 30 & 35.5 & 43 & 92 & $0 / 164.2$ & 183.6 & \\
\hline 1704 & 0 & 0 & 0 & - & - & - & $\ldots$ & 29.5 & 35 & 42.5 & 93 & $0 / 168.0$ & 182.9 & \\
\hline 2310 & 0 & 0 & 0 & $\cdots$ & - & $\ldots$ & - & 27 & 31.5 & 39 & 93 & $0 / 176.4$ & 176.9 & \\
\hline 2332 & 0 & 0 & 0 & - & $\cdots$ & - & - & 26.5 & 31 & $38.5+$ & 93 & $0.39 / 186.8$ & 176.7 & Flow Started \\
\hline 2343 & 0 & 0 & 0 & $\ldots$ & -- & $\cdots$ & -- & 26.5 & 31 & 38.5 & 92 & $1.72 / 220.8$ & 176.7 & \\
\hline 9605240539 & 0 & 0 & 0 & - & - & - & - & 26.5 & 31 & 38.5 & 93 & $4 . 8 \longdiv { 3 1 6 7 }$ & 170.2 & Ed’s Happy \\
\hline 0.830 & 0 & 0 & 0 & - & $\ldots$ & - & $m$ & 0 & 0 & 5 & 93 & $4.7 / 3822.5$ & 168.7 & \\
\hline
\end{tabular}




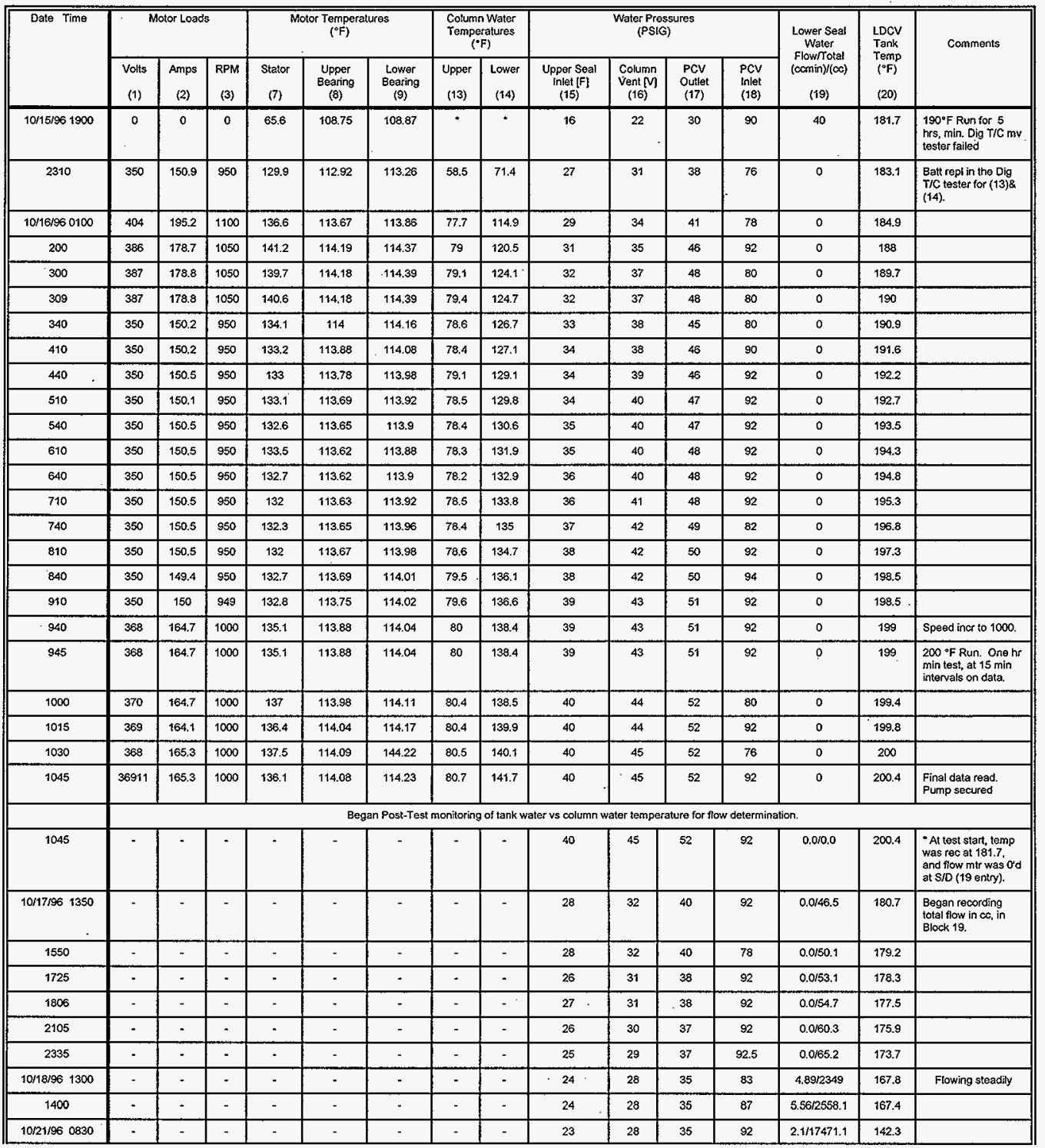




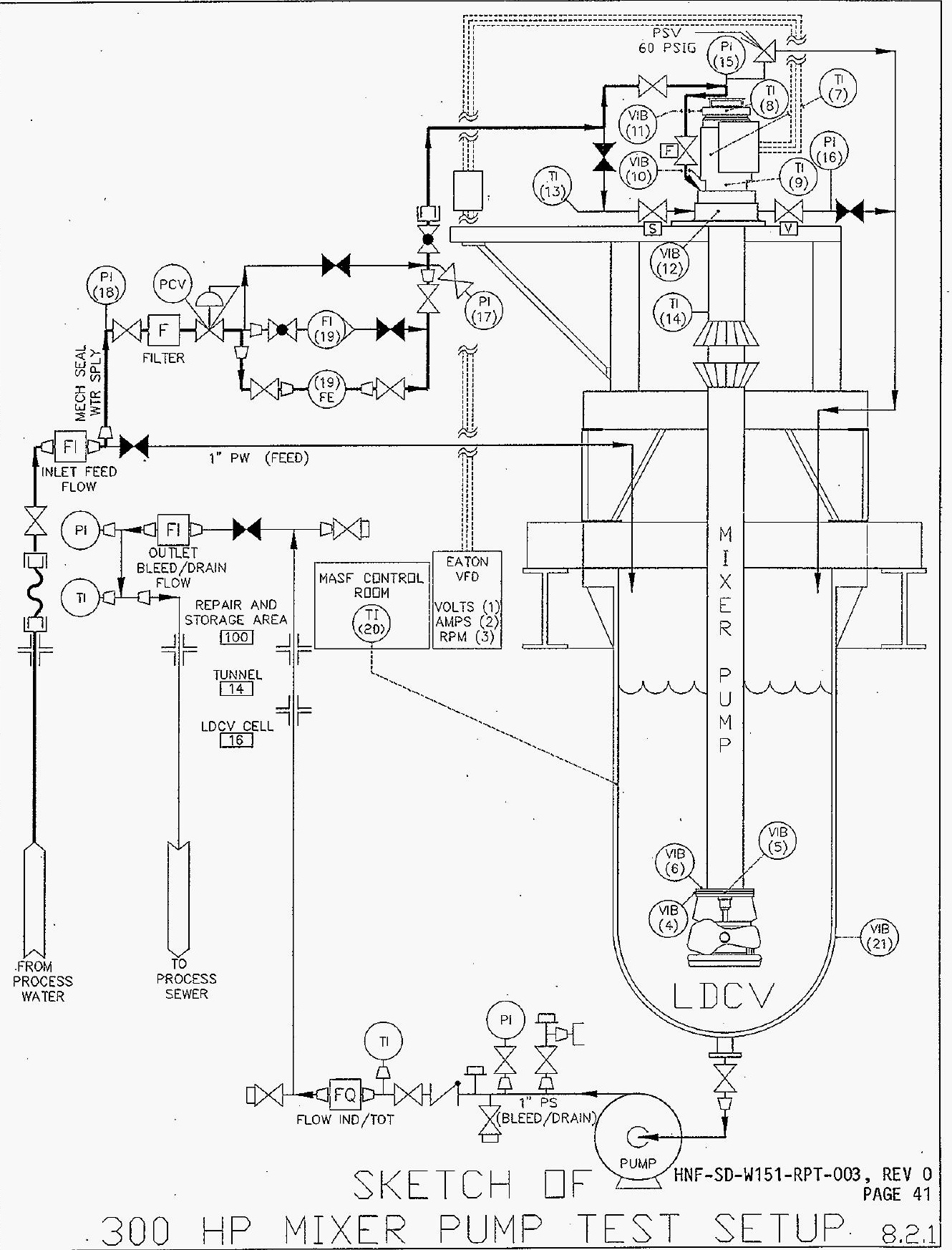




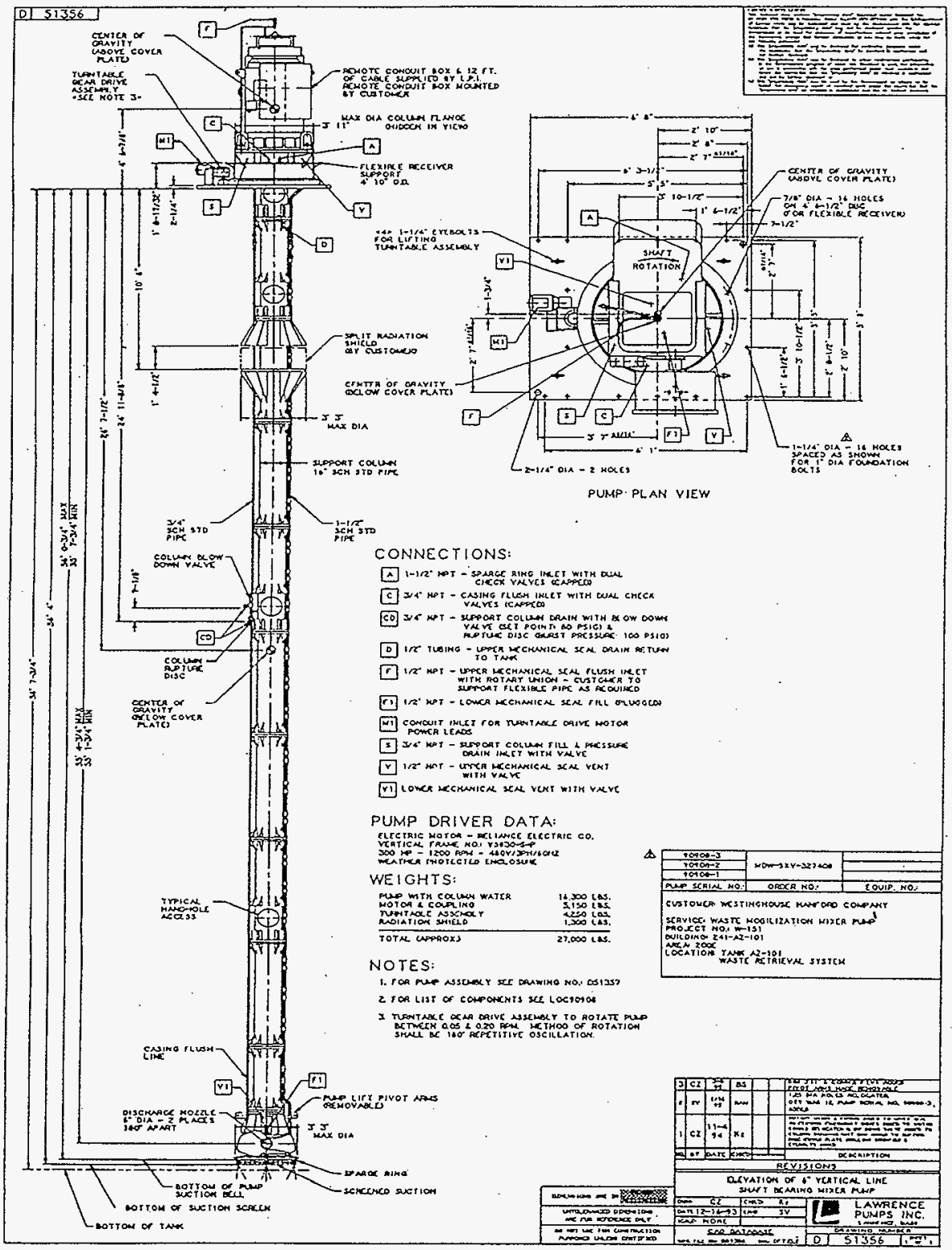

Elevation of 6" Vertical Line Shaft Bearing Pump - 8.2.2 


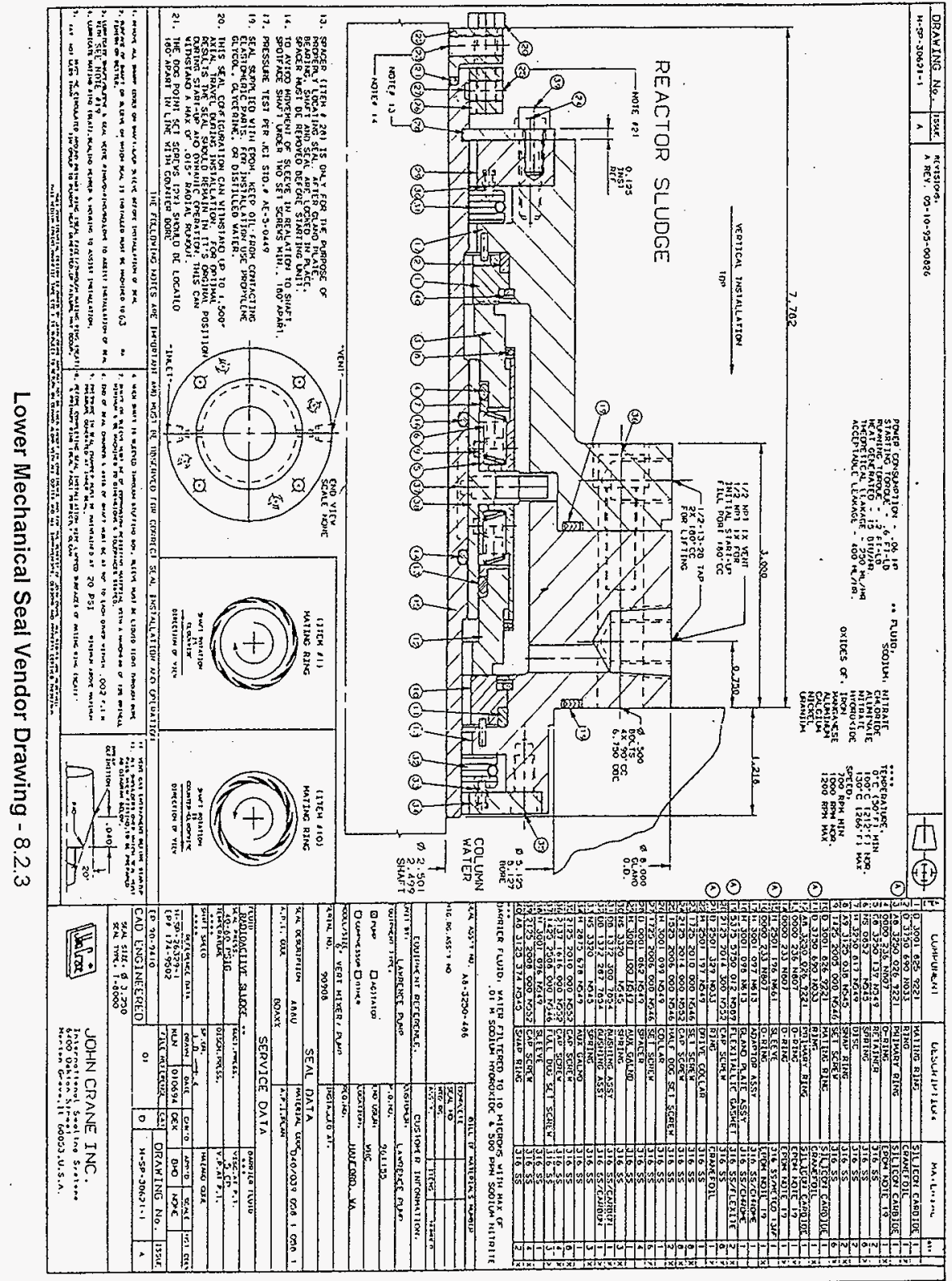


to $39 \forall d$

0 A $\exists y$ ' $E 00-1 d y-L S L M-O S-J N H$

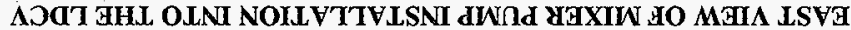

\section{I\# OLOHd}

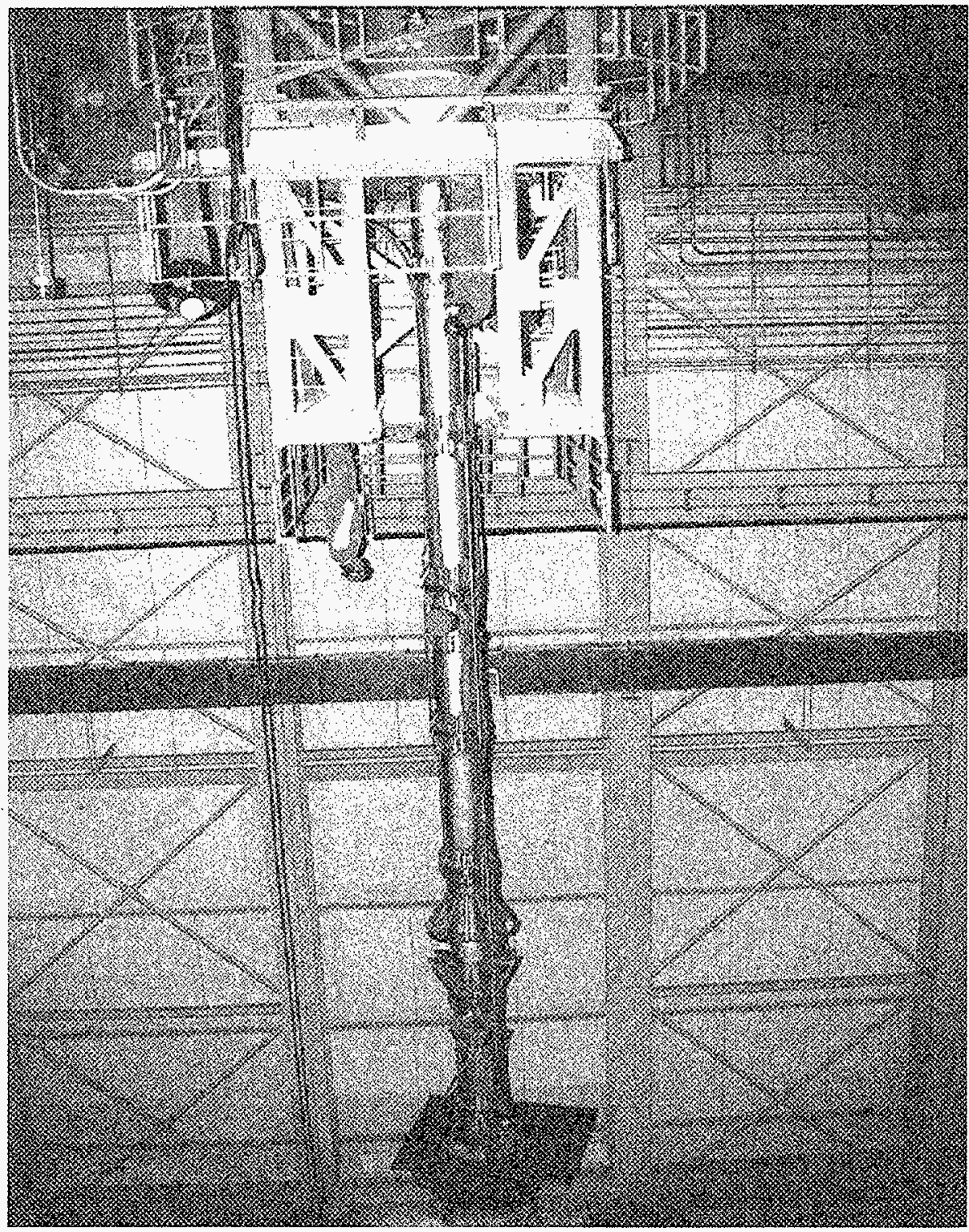


St $\exists$ G

$0 \wedge \exists y$ ' $800-1 d 8-L$ LLM-OS - - $N H$

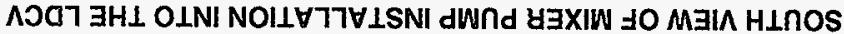 Z\# OLOHd}

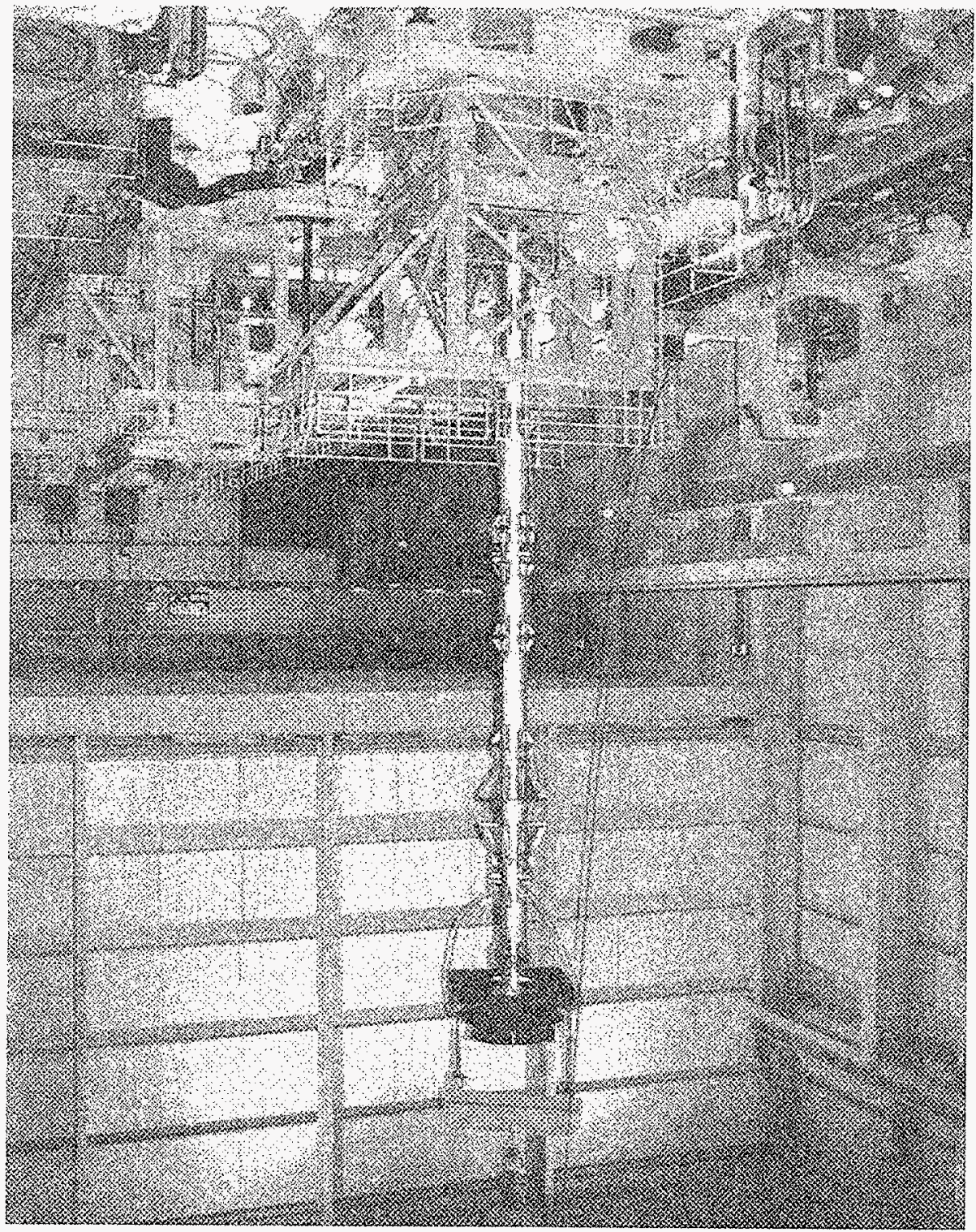




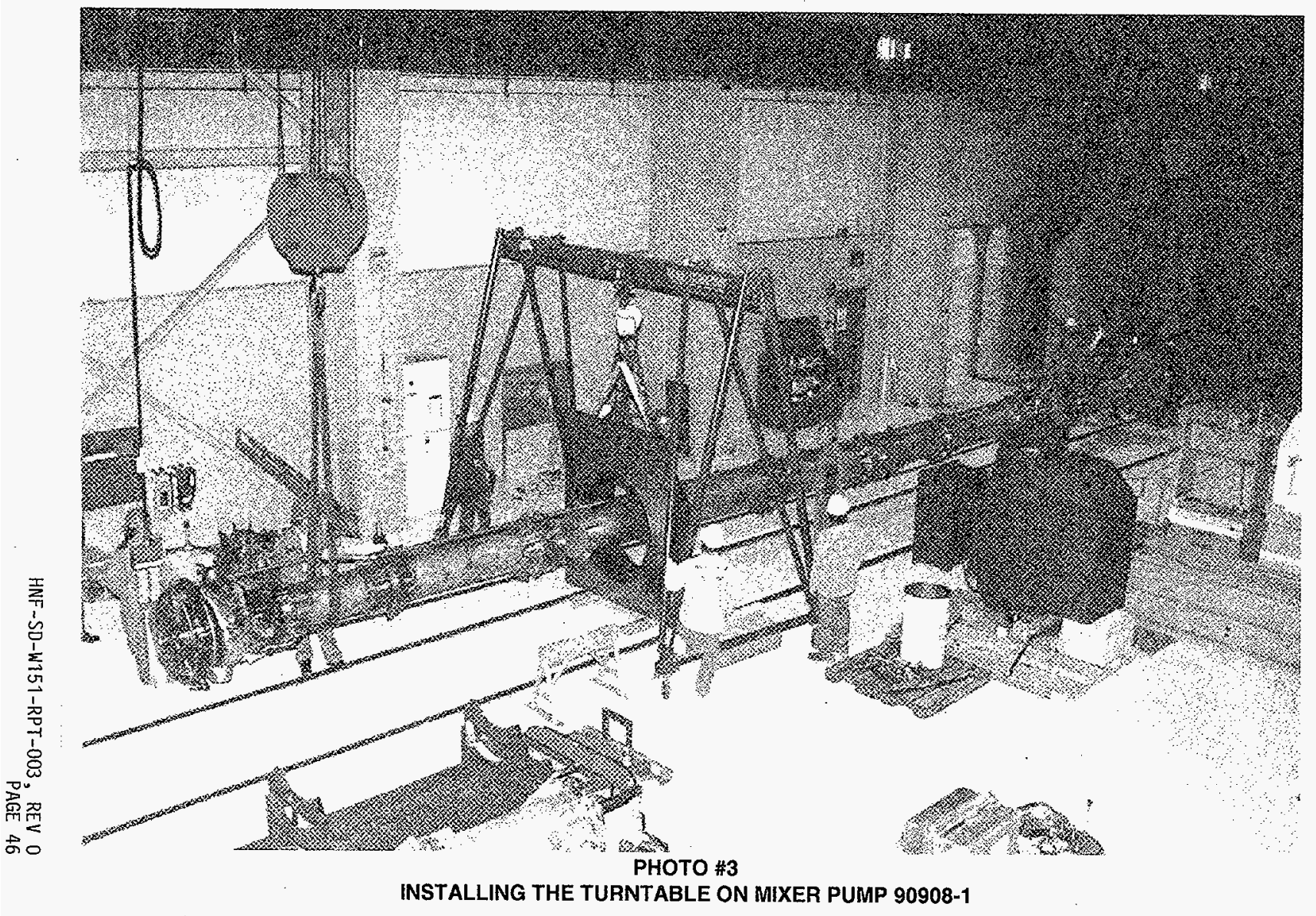



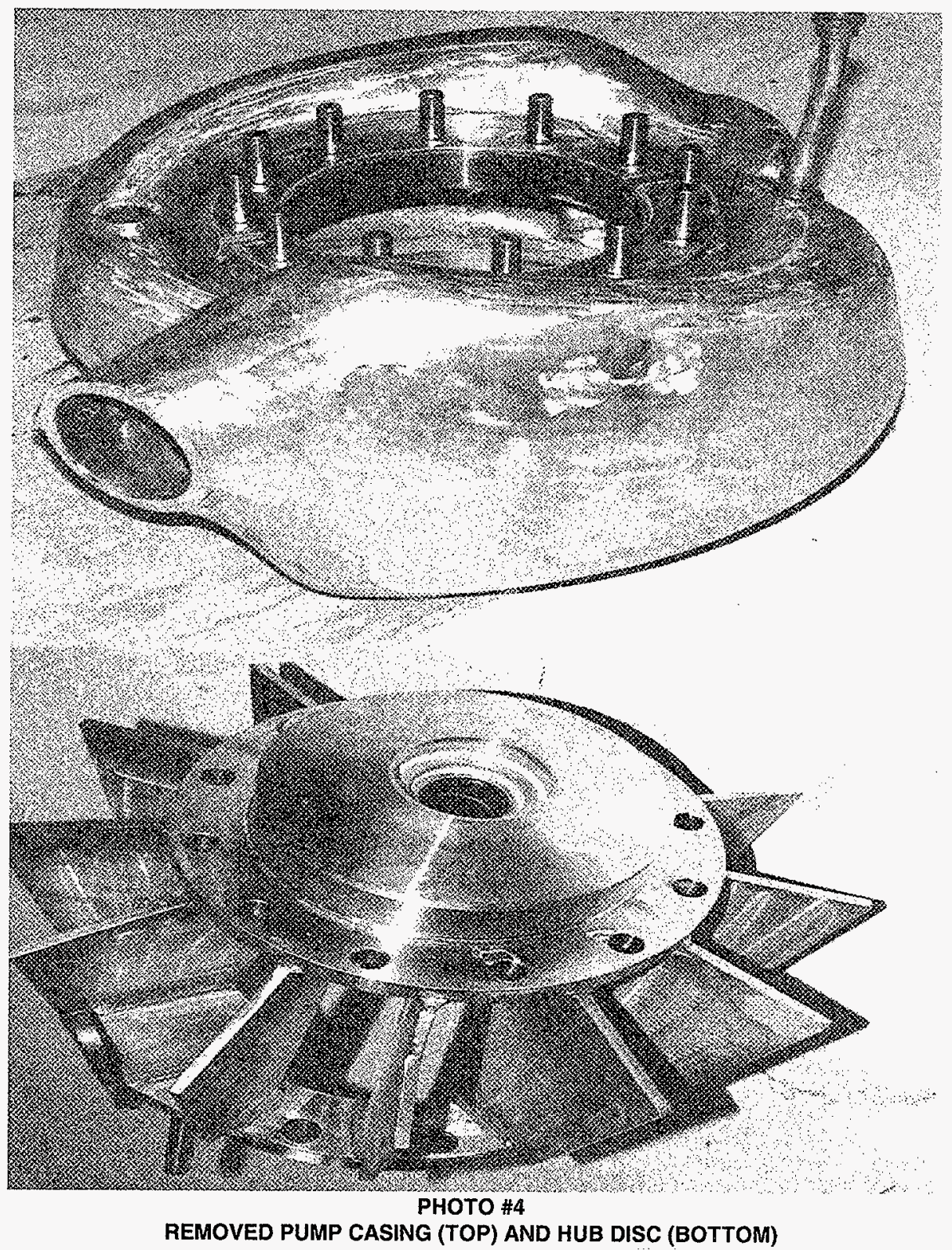

HNF-SD-W151-RPT-003, REV 0 

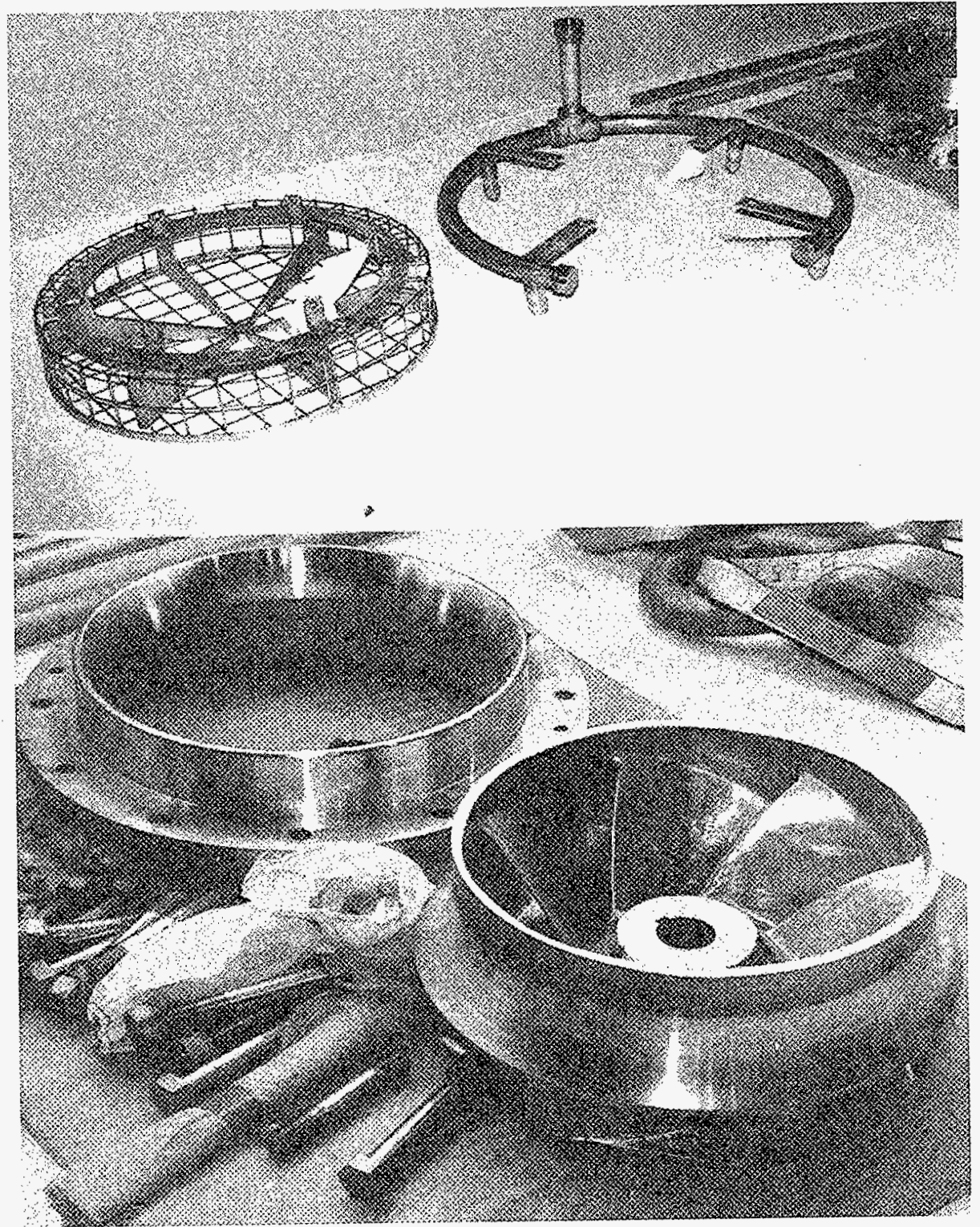


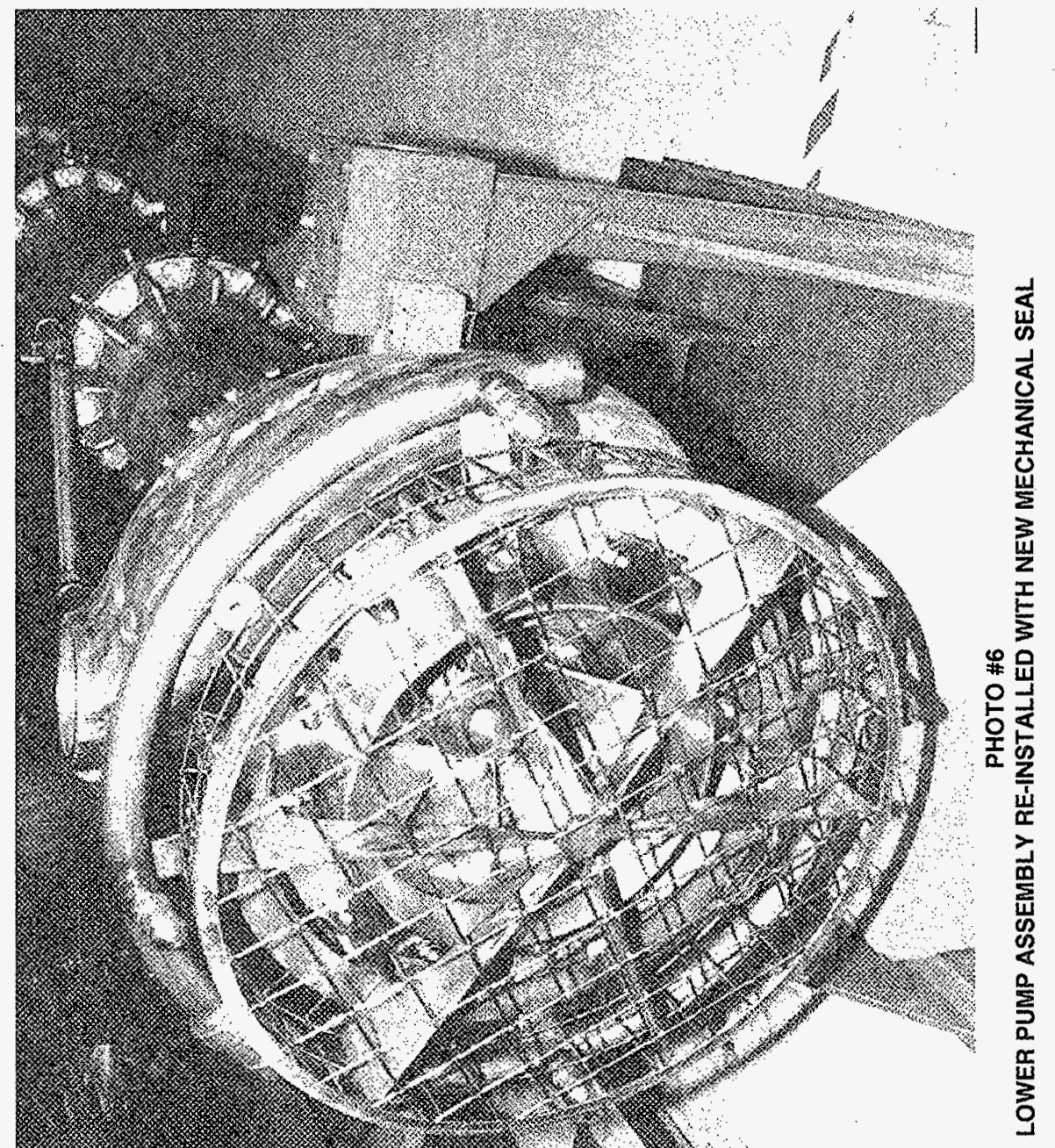

